\title{
Aerosol mass spectrometer constraint on the global secondary organic aerosol budget
}

\author{
D. V. Spracklen ${ }^{1}$, J. L. Jimenez ${ }^{2}$, K. S. Carslaw ${ }^{1}$, D. R. Worsnop ${ }^{3,4}$, M. J. Evans ${ }^{1}$, G. W. Mann ${ }^{1}$, Q. Zhang ${ }^{5}$,

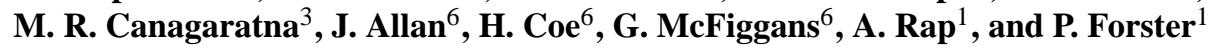 \\ ${ }^{1}$ School of Earth and Environment, University of Leeds, Leeds, LS2 9JT, UK \\ ${ }^{2}$ Department of Chemistry and Biochemistry, and CIRES, University of Colorado, Boulder, CO, USA \\ ${ }^{3}$ Aerodyne Research, Billerica, MA, USA \\ ${ }^{4}$ Department of Physics, University of Helsinki, Finland \\ ${ }^{5}$ Department of Environmental Toxicology, University of California, Davis, CA, USA \\ ${ }^{6}$ Centre for Atmospheric Science, School of Earth, Atmospheric and Environmental Sciences, University of Manchester, \\ Manchester, UK
}

Received: 29 December 2010 - Published in Atmos. Chem. Phys. Discuss.: 16 February 2011

Revised: 31 October 2011 - Accepted: 21 November 2011 - Published: 7 December 2011

\begin{abstract}
The budget of atmospheric secondary organic aerosol (SOA) is very uncertain, with recent estimates suggesting a global source of between 12 and $1820 \mathrm{Tg}(\mathrm{SOA}) \mathrm{a}^{-1}$. We used a dataset of aerosol mass spectrometer (AMS) observations from 34 different surface locations to evaluate the GLOMAP global chemical transport model. The standard model simulation (which included SOA from monoterpenes only) underpredicted organic aerosol (OA) observed by the AMS and had little skill reproducing the variability in the dataset. We simulated SOA formation from biogenic (monoterpenes and isoprene), lumped anthropogenic and lumped biomass burning volatile organic compounds (VOCs) and varied the SOA yield from each precursor source to produce the best overall match between model and observations. We assumed that SOA is essentially non-volatile and condenses irreversibly onto existing aerosol. Our best estimate of the SOA source is $140 \mathrm{Tg}(\mathrm{SOA}) \mathrm{a}^{-1}$ but with a large uncertainty range which we estimate to be $50-380 \mathrm{Tg}(\mathrm{SOA}) \mathrm{a}^{-1}$. We found the minimum in normalised mean error (NME) between model and the AMS dataset when we assumed a large SOA source $\left(100 \mathrm{Tg}(\mathrm{SOA}) \mathrm{a}^{-1}\right)$ from sources that spatially matched anthropogenic pollution (which we term antropogenically controlled SOA). We used organic carbon observations compiled by Bahadur et al. (2009) to evaluate our estimated SOA sources. We found that the model with a large anthropogenic SOA source was the most consistent with these observa-
\end{abstract}

Correspondence to: D. V. Spracklen (dominick@env.leeds.ac.uk) tions, however improvement over the model with a large biogenic SOA source $\left(250 \mathrm{Tg}(\mathrm{SOA}) \mathrm{a}^{-1}\right)$ was small. We used a dataset of ${ }^{14} \mathrm{C}$ observations from rural locations to evaluate our estimated SOA sources. We estimated a maximum of $10 \mathrm{Tg}(\mathrm{SOA}) \mathrm{a}^{-1}(10 \%)$ of the anthropogenically controlled SOA source could be from fossil (urban/industrial) sources. We suggest that an additional anthropogenic source is most likely due to an anthropogenic pollution enhancement of SOA formation from biogenic VOCs. Such an anthropogenically controlled SOA source would result in substantial climate forcing. We estimated a global mean aerosol direct effect of $-0.26 \pm 0.15 \mathrm{Wm}^{-2}$ and indirect (cloud albedo) effect of $-0.6_{-0.14}^{+0.24} \mathrm{Wm}^{-2}$ from anthropogenically controlled SOA. The biogenic and biomass SOA sources are not well constrained with this analysis due to the limited number of OA observations in regions and periods strongly impacted by these sources. To further improve the constraints by this method, additional OA observations are needed in the tropics and the Southern Hemisphere.

\section{Introduction}

Organic aerosol (OA) contributes about $50 \%$ of dry tropospheric submicron aerosol mass (Putaud et al., 2004; Murphy et al., 2006; Zhang et al., 2007) with important impacts on climate (Forster et al., 2007) and air quality. OA sources can be split into primary organic aerosol (POA) that is emitted directly to the atmosphere as particles, and secondary organic aerosol (SOA) that forms in the atmosphere from gasto-particle conversion. The global budget of SOA is very

Published by Copernicus Publications on behalf of the European Geosciences Union. 
uncertain. Recent top-down estimates, based either on the mass balance of volatile organic carbon (VOC) or on scaling of the sulfate budget, suggest a global source ranging from $120-1820 \mathrm{Tg}(\mathrm{SOA}) \mathrm{a}^{-1}$ (Goldstein and Galbally, 2007, Hallquist et al., 2009) ${ }^{1}$. Meanwhile atmospheric models typically use bottom-up estimates which combine emission inventories for VOCs with laboratory based SOA yields to give a global SOA formation of $12-70 \mathrm{Tg}(\mathrm{SOA}) \mathrm{a}^{-1}$ (Kanakidou et al., 2005). The current uncertainty in the global SOA source $\left(12-1820 \mathrm{Tg}(\mathrm{SOA}) \mathrm{a}^{-1}\right)$ is therefore very substantial.

In addition to the total budget of SOA being highly uncertain, the relative contributions from anthropogenic, biogenic, and biomass burning sources are also poorly constrained. Regional and global atmospheric models using "traditional" SOA parameterizations (those developed until 2006) formed SOA mostly from biogenic VOCs and typically showed large SOA underestimations in polluted regions (e.g. Heald et al., 2005; Volkamer et al., 2006; Hodzic et al., 2010a) but not for clean biogenic regions (Tunved et al., 2006; Chen et al., 2009; Hodzic et al., 2009; Slowik et al., 2010). Recently, formation of SOA from additional sources has been included in models. Several box (Dzepina et al., 2009), regional (Hodzic et al., 2010a; Tsimpidi et al., 2010) and global (Pye and Seinfeld, 2010) modelling studies have explored enhanced formation of SOA from semivolatile and intermediate volatility organic compounds (S/IVOC), which are SOA precursors emitted by anthropogenic and biomass burning sources (Robinson et al., 2007). These studies reported that such precursors may be an important and previously neglected regional and global SOA source. However, there is still substantial uncertainty in the concentrations, reaction rates, and SOA yields of S/IVOC precursors. Some new parameterizations of SOA formation from anthropogenic VOCs (Lane et al., 2008; Tsimpidi et al., 2010) result in very high mass yields (e.g. $\sim 100 \%$ for toluene after $\sim 3$ days, Dzepina et al., 2010), but are not yet fully supported by laboratory data. SOA formed from biomass burning precursors is gaining attention as a potentially important source, although both field (Capes et al., 2008; Yokelson et al., 2009; DeCarlo et al., 2010) and laboratory (Grieshop et al., 2009) studies appear to show high variability in the net addition (or sometimes loss) of OA mass due to SOA formation and POA aging from this source. In cloud formation of SOA may be an additional source of SOA (e.g., Carlton et al., 2006; Chen et al., 2007; Tan et al., 2010).

At the global scale, modelling studies using traditional SOA models predict that the formation of SOA from biogenic sources greatly exceeds that from anthropogenic sources (Tsigaridis et al., 2006; Tsigaridis and Kanakidou, 2007; Heald et al., 2008; Henze et al., 2008), while newer models predict a larger share for anthropogenic SOA (Farina et al., 2010, Pye and Seinfeld, 2010). The importance of bio-

\footnotetext{
${ }^{1}$ We assume a conversion factor of $2 \mathrm{Tg}(\mathrm{SOA}) / \mathrm{Tg}(\mathrm{C})$ over space and time scales relevant to global models (Turpin and Lim, 2001; Aiken et al., 2008).
}

genic SOA appears to be consistent with the large fraction of non-fossil carbon detected in ambient OA (e.g., Hodzic et al., 2010b). Even in polluted regions, where concentrations of OA are enhanced, substantial fractions of non-fossil carbon are detected (e.g., Schichtel et al., 2008) leading to the suggestion that biogenic SOA formation may be enhanced by anthropogenic pollution (de Gouw et al., 2005; Weber et al., 2007; Goldstein et al., 2009; Hoyle et al., 2011; Worton et al., 2011). Potential mechanisms for such enhanced formation include higher aerosol acidity (e.g. Jang et al., 2002; Surratt et al., 2010, Froyd et al., 2010), $\mathrm{NO}_{x}$ levels (Chan et al., 2010; Ng et al., 2007b, 2008) and speciation (e.g. Chan et al., 2010), enhanced pollution-related OA and oxidant levels (Tsigaridis and Kanakidou, 2007), and oxidant speciation (e.g. $\mathrm{Ng}$ et al., 2008). A recent study predicted a factor of 2 enhancement of biogenic SOA by pollution in the US, due primarily to increased NOx concentrations that enhance biogenic VOC oxidation, and through anthropogenic POA acting as a medium for adsorption of condensable species of biogenic origin (Carlton et al., 2010). Not all of the observed non-fossil carbon is due to biogenic SOA, however, as important contributions also arise due to biomass burning, biofuel use, and of non-fossil urban OA sources (Hodzic et al., 2010b; Hildemann et al., 1994).

In this paper we use a global aerosol microphysics model and a global dataset of OA observations from the aerosol mass spectrometer (AMS) to produce a new top-down estimate of the global SOA budget. We simulated OA using a 3-D global chemical transport model (Sect. 2.1) and tested the model response to a range of different SOA sources (Sect. 2.2). We used AMS observations (Sect. 2.3) to evaluate these model simulations. We ran multiple model simulations with different SOA sources (Sect. 3.1). To estimate the SOA sources that resulted in the best match between the model and AMS observations we made linear interpolations between the OA simulated by the global model runs (Sect. 3.2 and 3.3). We tested the SOA sources estimated with this method in the global model (Sect. 3.4) and evaluated against the AMS dataset and independent observations from Bahadur et al. (2009) (Sect. 3.5). Finally to help further understand the different sources of SOA we evaluated against ${ }^{14} \mathrm{C}$ radiocarbon observations (Sect. 3.8).

\section{Methods}

\subsection{GLOMAP global aerosol model}

We used the Global Model of Aerosol Processes (GLOMAP) (Spracklen et al., 2005a, b) which is an extension of the TOMCAT 3-D global chemical transport model (Chipperfield, 2006). We used the modal version of the model (GLOMAP-mode) where the aerosol size distribution is treated using a two-moment modal scheme (Manktelow et al., 2007; Mann et al., 2010). We simulated sulfate, sea-salt, 
elemental carbon, POA and SOA as distinct aerosol components and simulated the aerosol size distribution with 5 modes: hygroscopic nucleation, Aitken, accumulation and coarse modes plus a non-hygroscopic Aitken mode. We do not treat dust, ammonium or nitrate aerosol. The model was run for the year 2000 using a horizontal resolution of $\sim 2.8^{\circ} \times 2.8^{\circ}$ and with 31 vertical levels between the surface and $10 \mathrm{hPa}$.

The model described in Mann et al. (2010) only includes SOA from monoterpenes. For this study we implemented a new SOA scheme in the model. We included SOA formation from 4 VOC classes: monoterpenes, isoprene, lumped anthropogenic VOCs $\left(\mathrm{VOC}_{\mathrm{A}}\right)$ and lumped biomass burning $\operatorname{VOCs}\left(\mathrm{VOC}_{\mathrm{BB}}\right)$.

Throughout the paper we term the SOA that is linked to anthropogenic activity as "anthropogically controlled" to underscore the fact that it could represent any source with a spatial pattern similar to that of anthropogenic $\mathrm{CO}$ emissions which may include the following (a) SOA formed directly from oxidation of anthropogenic VOCs, (b) IVOCs,(c) enhancement of biogenic SOA production due to anthropogenic pollution, (d) meat cooking, (e) wood smoke emissions that are not in standard emission inventories. We use ${ }^{14} \mathrm{C}$ data in an attempt to differentiate contemporary from fossil sources as described below. However, our analysis method provides little mechanistic information that can help determine the dominant formation pathway.

In a set of sensitivity simulations we allowed POA to convert directly to SOA with a half life which we set at between 1 and 8 days. Much of this POA aging is thought to occur via the gas-phase (Robinson et al., 2007) and thus the processed material can be correctly referred to as SOA. Some of the POA may be oxidized heterogeneously in the particle phase, especially at very long aging times (George and Abbatt, 2010), and would more correctly be referred to as oxidized POA.

Emissions of POA from fossil fuel $\left(3.2 \mathrm{Tg}(\mathrm{OA}) \mathrm{a}^{-1}\right)$, biofuel $\left(9.1 \mathrm{Tg}(\mathrm{OA}) \mathrm{a}^{-1}\right)$ and wildfire $\left(34.7 \mathrm{Tg}(\mathrm{OA}) \mathrm{a}^{-1}\right)$ are from the AEROCOM inventory (Dentener et al., 2006). This inventory bases carbonaceous combustion aerosol emissions from wildfire on the Global Fire Emission Database (GFED) (van der Werf et al., 2004) and carbonaceous combustion aerosol emissions from fossil fuel and biofuel burning on the Speciated Particulate Emissions Wizard (SPEW) (Bond et al., 2004). Emissions of monoterpenes and isoprene were taken from the Global Emissions Inventory Activity (GEIA), based on Guenther et al. (1995). For emissions of $\mathrm{VOC}_{\mathrm{A}}$ and $\mathrm{VOC}_{\mathrm{BB}}$ we scaled gridded $\mathrm{CO}$ emissions from the IIASA (International Institute for Applied Systems Analysis) dataset (Dentener et al., 2005). This scaling is supported by the very frequently observed proportionality of SOA formation to $\mathrm{CO}$ in polluted regions (e.g., de Gouw et al., 2008; Dzepina et al., 2009; de Gouw and Jimenez, 2009; DeCarlo et al., 2010). CO emissions from anthropogenic activity $\left(470.5 \mathrm{Tg}(\mathrm{CO}) \mathrm{a}^{-1}\right)$
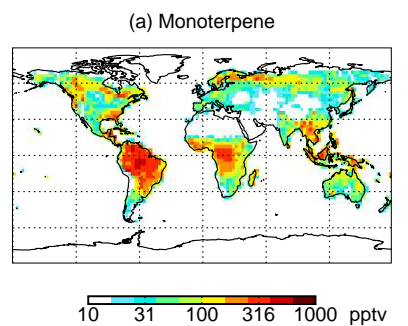

(c) $\operatorname{VOC}_{\mathrm{A}}$
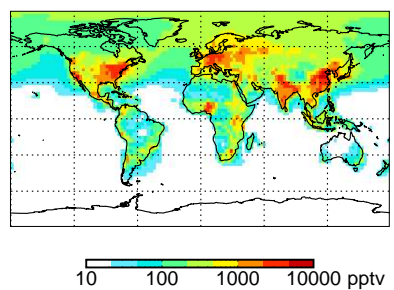

(b) Isoprene

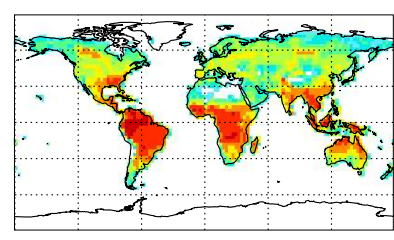

$10 \quad 100 \quad 1000 \quad 10000$ pptv

(d) $\mathrm{VOC}_{\mathrm{BB}}$

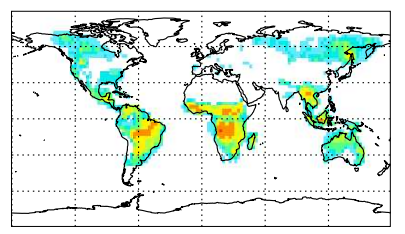

$10 \quad 100 \quad 1000 \quad 10000$ pptv
Fig. 1. Simulated annual mean surface concentrations of (a) monoterpene, (b) isoprene, (c) anthropogenic $\mathrm{VOC}\left(\mathrm{VOC}_{\mathrm{A}}\right)$, (d) biomass burning $\operatorname{VOC}\left(\mathrm{VOC}_{\mathrm{BB}}\right)$.

and biomass burning $\left(507.5 \mathrm{Tg}(\mathrm{CO}) \mathrm{a}^{-1}\right)$ were scaled using $\mathrm{VOC} / \mathrm{CO}$ mass ratios of $0.29 \mathrm{~g} / \mathrm{g}$ and $0.10 \mathrm{~g} / \mathrm{g}$ respectively so as to reproduce the global sum of VOC emissions from the Emissions Database for Atmospheric Research (EDGAR) for anthropogenic $\left(127 \mathrm{Tg}(\mathrm{VOC}) \mathrm{a}^{-1}\right)$ and biomass burning $\left(49 \mathrm{Tg}(\mathrm{VOC}) \mathrm{a}^{-1}\right)$ sources.

We included reactions of monoterpenes and isoprene with $\mathrm{OH}, \mathrm{O}_{3}$ and $\mathrm{NO}_{3}$, and reactions of $\mathrm{VOC}_{\mathrm{A}}$ and $\mathrm{VOC}_{\mathrm{BB}}$ with $\mathrm{OH}$ (Table 1). We assumed these reactions form a surrogate oxidation product that can condense into the particle phase. The reaction rate of $\mathrm{VOC}_{\mathrm{A}}$ with $\mathrm{OH}$ is based on field observations (de Gouw et al., 2008; DeCarlo et al., 2010) and results in SOA production on timescales of 1 day or more. Slower SOA formation processes (e.g., those from second or higher oxidation pathways) which will not lead to distinct spatial patterns in OOA concentrations will be more difficult to constrain with our method. For the reactions of $\mathrm{VOC}_{\mathrm{A}}$ and $\mathrm{VOC}_{\mathrm{BB}}$ we tested the sensitivity to changes in the reaction rate. Concentrations of oxidants were specified using 6hourly monthly mean 3-D gridded concentration fields from a TOMCAT simulation with detailed tropospheric chemistry (Arnold et al., 2005). Figure 1 shows simulated surface concentrations of the different VOCs.

Condensable gas-phase species (including VOC oxidation products and $\mathrm{H}_{2} \mathrm{SO}_{4}$ ) are allowed to condense on all aerosol modes. In all simulations we assume an SOA/OC mass ratio of 2.0. We assumed the above reactions form a surrogate oxidation product that condenses kinetically, and irreversibly, as SOA with negligible vapour pressure onto pre-existing aerosol. Although fresh SOA is known to be semivolatile (Odum et al., 1996; Cappa and Jimenez, 2010), it has been recently shown that aged SOA has low volatility (Jimenez et al., 2009; Cappa and Jimenez, 2010) and may form a highly 
Table 1. Reactions of VOCs: anthropogenic $\left(\mathrm{VOC}_{\mathrm{A}}\right)$, biomass burning $\left(\mathrm{VOC}_{\mathrm{BB}}\right)$ and biogenic (isoprene and $\alpha$-pinene; $\mathrm{VOC}_{\mathrm{B}}$ ) to produce an assumed condensable product $\left(\mathrm{SOA}_{\mathrm{g}}\right)$ with yield ( $\mathrm{y} 1$ to y10). The reaction rate of Reactions (7-10) were scaled by a linear factor (r7 through r10).

\begin{tabular}{|c|c|c|}
\hline & Reaction & Rate constant \\
\hline 1 & $\alpha$-pinene $+\mathrm{OH} \rightarrow$ y1. SOAg & $1.2 \times 10^{-11} \exp (444 / T)$ \\
\hline 2 & $\alpha$-pinene $+\mathrm{O}_{3} \rightarrow \mathrm{y} 2 . \mathrm{SOAg}$ & $1.01 \times 10^{-15} \exp (-732 / T)$ \\
\hline 3 & $\alpha$-pinene $+\mathrm{NO}_{3} \rightarrow \mathrm{y} 3 . \mathrm{SOAg}$ & $1.19 \times 10^{-12} \exp (490 / T)$ \\
\hline 4 & isoprene $+\mathrm{OH} \rightarrow \mathrm{y} 4 . \mathrm{SOAg}$ & $2.7 \times 10^{-11} \exp (390 / T)$ \\
\hline 5 & isoprene $+\mathrm{O}_{3} \rightarrow$ y5. SOAg & $1 \times 10^{-14} \exp (-1995 / T)$ \\
\hline 6 & isoprene $+\mathrm{NO}_{3} \rightarrow \mathrm{y} 6 . \mathrm{SOAg}$ & $3.15 \times 10^{-12} \exp (-450 / T)$ \\
\hline 7 & $\mathrm{VOC}_{\mathrm{A}}+\mathrm{OH} \rightarrow \mathrm{y} 7 . \mathrm{SOAg}$ & $5 \times 10^{-12} \times \mathrm{r} 7(*)$ \\
\hline 8 & $\mathrm{VOC}_{\mathrm{BB}}+\mathrm{OH} \rightarrow \mathrm{y} 8 . \mathrm{SOAg}$ & $5 \times 10^{-12} \times \mathrm{r} 8$ \\
\hline 9 & $\mathrm{VOC}_{B}+\mathrm{VOC}_{\mathrm{A}} \rightarrow \mathrm{y} 9 . \mathrm{SOAg}+\mathrm{VOC}_{\mathrm{A}}$ & $5 \times 10^{-16} \times \mathrm{r} 9$ \\
\hline 10 & $\mathrm{VOC}_{B}+\mathrm{SO}_{2} \rightarrow \mathrm{y} 10 . \mathrm{SOAg}+\mathrm{SO}_{2}$ & $1 \times 10^{-14} \times \mathrm{r} 10$ \\
\hline
\end{tabular}

$(*)$ : this estimated rate is based on the summaries of field observations by de Gouw et al. (2008) and DeCarlo et al. (2010).

viscous glassy state (Virtanen et al., 2010; Cappa and Wilson, 2010; Vaden et al., 2011), which is likely to be most relevant to the time and length scales of our global modelling study. Recently, Riipinen et al. (2011) examined particle formation events to show that roughly half of freshly-formed condensing organic vapours appears to be effectively non-volatile. Additionally, we have previously shown that kinetic uptake of SOA onto pre-existing aerosol allows the model to simulate the growth of newly formed particles in the 3 to $100 \mathrm{~nm}$ size range (Spracklen et al., 2006, 2008a). But we note that volatility is a further free parameter in the model that should be investigated in the future.

We do not include an OA source from the oceans (e.g., Spracklen et al., 2008b) because the size distribution of the source is not well known and it is not clear what fraction of this source is primary as opposed to secondary. Oceanic isoprene emissions are thought to be $<1 \%$ of the terrestrial source (Arnold et al., 2009) while the monoterpene source is very uncertain (Yassa et al., 2008). Since the concentrations of $\mathrm{OA}$ arising from the marine source are generally low in comparison to continental regions (Spracklen et al., 2008b; Lapina et al., 2011) and since the majority of the AMS observations used here are from continental locations this is unlikely to be an issue in our analysis.

\subsection{SOA simulations}

We conducted a set of annual simulations (detailed in Table 2) where we varied the sources of SOA. We assume that the spatial pattern of VOC and POA emissions are correct. In each set of simulations that are described below, the source of SOA from the VOC precursors was varied by altering the yield ( $\mathrm{y} 1$ to $\mathrm{y} 10)$ of the reactions in Table 1 . The source of SOA from ageing of POA was altered by changing the lifetime of conversion of POA to SOA. The upper limit for each source was chosen where an increase in the source degraded the comparison with the AMS observations that are described in the following section. In the first set of model experiments (simulations 1-5) we varied the SOA formation from monoterpenes $\left(0-246 \mathrm{Tg}(\mathrm{SOA}) \mathrm{a}^{-1}\right)$ and isoprene $\left(0-52 \operatorname{Tg}(\mathrm{SOA}) \mathrm{a}^{-1}\right)$. The standard model (Mann et al., 2010, simulation 1) only includes SOA from monoterpenes. In the second set of experiments (simulations 6-7) we included SOA formation from biomass burning VOCs $\left(0-212 \mathrm{Tg}(\mathrm{SOA}) \mathrm{a}^{-1}\right)$. In the third set of experiments (simulations 8-10) we included SOA from ageing of POA (0$\left.39.5 \mathrm{Tg}(\mathrm{SOA}) \mathrm{a}^{-1}\right)$. In the fourth set of experiments ( $\mathrm{sim}$ ulations 11-24, reaction 7) we included SOA from anthropogenic VOCs $\left(0-117 \mathrm{Tg}(\mathrm{SOA}) \mathrm{a}^{-1}\right)$. In a final set of experiments we tested a number of potential mechanisms under which formation of SOA from biogenic VOCs could be enhanced by anthropogenic pollution. We altered the SOA yield from monoterpenes separately with $\mathrm{OH}, \mathrm{O}_{3}$ and $\mathrm{NO}_{3}$ (simulations 25-27), included $\mathrm{SO}_{2}$ catalysed formation of SOA from isoprene and monoterpenes (simulations 28-29, as a representation of acid-catalysed biogenic SOA formation) and included $\mathrm{VOC}_{\mathrm{A}}$ catalysed formation of SOA from isoprene and monoterpenes (simulations $30-33$, as a representation of biogenic SOA enhancement by anthropogenic pollutants with similar emission pattern as anthropogenic $\mathrm{CO}$ and lifetime similar to our assumed $\mathrm{VOC}_{\mathrm{A}}$ ).

\subsection{AMS observations}

We compared GLOMAP against a dataset of OA measurements from the AMS. The AMS has been described in detail previously (Canagaratna et al., 2007), and provides fast on-line submicron non-refractory (NR) aerosol composition. NR is operationally defined based on evaporation under a few seconds under the AMS conditions $\left(600^{\circ} \mathrm{C}\right.$, high vacuum) and in practice includes organic species and most inorganic salts and excludes black carbon, mineral dust, and sea salt. Factor analysis of AMS spectra allows the identification of OA components, principally hydrocarbon-like OA (HOA, a surrogate for combustion POA, and here also including primary biomass burning OA, P-BBOA) and oxygenated OA (OOA, a surrogate for SOA from all sources). Based on many recent observations (e.g. Zhang et al., 2005; Lanz et al., 2007; Dzepina et al., 2009; Aiken et al., 2008, 2009), we assumed that simulated POA (including that from biomass burning) is equivalent to observed HOA and that simulated SOA (and including SOA formed from oxidised POA where this was treated in the model) is equivalent to observed OOA. The identification of different OA components is useful for our analysis of SOA sources as we discuss in Sect. 3.2.

We supplemented the dataset of AMS observations compiled by Zhang et al. (2007) with 10 more recent observations (Table 3) giving a total of 47 average observations from 34 separate locations. Each observation is typically the average of $\sim 1$ month of continuously sampled data at ground locations. The majority of our observations are near sea-level 
Table 2. Summary statistics for the evaluation of simulated sulfate, OA, HOA and OOA against AMS observations. Comparison at AMS locations classified as remote (see Sect. 2.3) given in parenthesis. The SOA source from monoterpenes $\left(S_{\mathrm{M}}\right)$, isoprene $\left(S_{\mathrm{I}}\right)$, anthropogenic $\operatorname{VOC}\left(S_{\mathrm{A}}\right)$, biomass burning VOC $\left(S_{\mathrm{BB}}\right)$ and from oxidation of POA to SOA $\left(S_{\mathrm{P}}\right)$, are detailed for each simulation.

\begin{tabular}{|c|c|c|c|c|c|c|c|c|c|c|}
\hline \multirow[t]{2}{*}{$\#$} & \multirow{2}{*}{$\begin{array}{l}\text { SOA yield }(\mathrm{y}) \text {, } \\
\text { reaction rate } \\
(\mathrm{r}) \text {, and } \mathrm{POA} \\
\text { half-life }\left(\tau_{\mathrm{p}}\right)^{\mathrm{a}}\end{array}$} & \multicolumn{5}{|c|}{ Global SOA source ${ }^{b} / \operatorname{Tg}(\mathrm{SOA}) \mathrm{a}^{-1}$} & \multicolumn{4}{|c|}{ Summary statistics ${ }^{\mathrm{c}}$} \\
\hline & & $S_{\mathrm{M}}$ & $\mathrm{S}_{\mathrm{I}}$ & $\mathrm{S}_{\mathrm{A}}$ & $S_{\mathrm{BB}}$ & $S_{\mathrm{P}}$ & $\begin{array}{l}\mathrm{NMB} / \\
\%\end{array}$ & $\begin{array}{l}\text { NME/ } \\
\%\end{array}$ & $\begin{array}{l}\text { RMSE/ } \\
\mu \mathrm{g} \mathrm{m}^{-3}\end{array}$ & $R^{2}$ \\
\hline \multicolumn{11}{|c|}{ Comparison against observed sulfate } \\
\hline 1 & & N/A & N/A & N/A & N/A & N/A & $\begin{array}{l}18 \\
(10)\end{array}$ & $66(65)$ & $\begin{array}{l}3.0 \\
(3.0)\end{array}$ & $\begin{array}{l}0.36 \\
(0.26)\end{array}$ \\
\hline \multicolumn{11}{|c|}{ Comparison against observed OA } \\
\hline 1 & $y 1-3=26 \%$ & 32.3 & 0. & 0. & 0. & 0. & $\begin{array}{l}-68 \\
(-51)\end{array}$ & $74(67)$ & $5.1(2.3)$ & $\begin{array}{l}0.27 \\
(0.12)\end{array}$ \\
\hline 3 & $\mathrm{y} 1-3=198 \%$ & 246. & 0. & 0 & 0 & 0. & $\begin{array}{l}8 \\
(67)\end{array}$ & $\begin{array}{l}96 \\
(146)\end{array}$ & $5.9(5.3)$ & $\begin{array}{l}0.12 \\
(0.05)\end{array}$ \\
\hline 33 & $\begin{array}{l}\text { Optimised } \\
\text { yields }\end{array}$ & 6.5 & 6.5 & 100. & 3. & 23. & $\begin{array}{l}-12 \\
(28)\end{array}$ & $\begin{array}{l}54 \\
(53)\end{array}$ & $3.9(2.0)$ & $\begin{array}{l}0.31 \\
(0.43)\end{array}$ \\
\hline 34 & $\begin{array}{l}\text { Optimised } \\
\text { yields }\end{array}$ & 195 & 6.5 & 10. & 3. & 23. & $\begin{array}{l}-3 \\
(49)\end{array}$ & $\begin{array}{l}85 \\
(125)\end{array}$ & $5.4(4.4)$ & $\begin{array}{l}0.14 \\
(0.08)\end{array}$ \\
\hline \multicolumn{11}{|c|}{ Comparison against observed OOA } \\
\hline 1 & $\mathrm{y} 1-3=26 \%$ & 32.3 & 0. & 0. & 0. & 0. & $\begin{array}{l}-85 \\
(-80)\end{array}$ & $\begin{array}{l}87 \\
(87)\end{array}$ & $4.3(2.7)$ & $\begin{array}{l}0.00 \\
(0.02)\end{array}$ \\
\hline 2 & $\mathrm{y} 1-3=130 \%$ & 161.5 & 0. & 0 . & 0. & 0. & $\begin{array}{l}-24 \\
(-3)\end{array}$ & $\begin{array}{l}94 \\
(125)\end{array}$ & $4.3(3.7)$ & $\begin{array}{l}0.00 \\
(0.02)\end{array}$ \\
\hline 3 & $\mathrm{y} 1-3=198 \%$ & 246.0 & 0. & 0. & 0. & 0. & $\begin{array}{l}16 \\
(48)\end{array}$ & $\begin{array}{l}118 \\
(160)\end{array}$ & $5.3(5.2)$ & $\begin{array}{l}0.00 \\
(0.02)\end{array}$ \\
\hline 4 & $\begin{array}{l}\mathrm{y} 1-3=26 \% \\
\mathrm{y} 4-6=6 \%\end{array}$ & 32.3 & 26.2 & 0. & 0. & 0. & $\begin{array}{l}-77 \\
(-70)\end{array}$ & $85(91)$ & $4.3(2.7)$ & $\begin{array}{l}0.00 \\
(0.02)\end{array}$ \\
\hline 5 & $\begin{array}{l}\mathrm{y} 1-3=26 \% \\
\mathrm{y} 4-6=12 \%\end{array}$ & 32.3 & 52.4 & 0. & 0. & 0. & $\begin{array}{l}-68 \\
(-59)\end{array}$ & $85(96)$ & $4.3(2.7)$ & $\begin{array}{l}0.00 \\
(0.02)\end{array}$ \\
\hline 6 & $\begin{array}{l}\mathrm{y} 1-3=26 \% \\
\mathrm{y} 4-6=6 \% \\
\mathrm{y} 8=90 \%\end{array}$ & 32.3 & 26.2 & 0.0 & 42.3 & 0. & $\begin{array}{l}-71 \\
(-61)\end{array}$ & $81(85)$ & $4.0(2.6)$ & $\begin{array}{l}0.03 \\
(0.00)\end{array}$ \\
\hline 7 & $\begin{array}{l}\mathrm{y} 1-3=26 \% \\
\mathrm{y} 4-6=6 \% \\
\mathrm{y} 8=180 \%\end{array}$ & 32.3 & 26.2 & 0.0 & 84.6 & 0. & $\begin{array}{l}-65 \\
(-51)\end{array}$ & $82(88)$ & $3.9(2.6)$ & $\begin{array}{l}0.03 \\
(0.00)\end{array}$ \\
\hline
\end{tabular}

and in the boundary layer (BL). A few observations are from high-altitude sites which may sample free tropospheric air for parts of the observation period. We included 4 observations from aircraft where these extended the geographical spread of our dataset. For these experiments we report the average of the BL data. Our dataset has limited information on the concentrations of OA above the BL. Since recent aircraft observations (Heald et al., 2006; Dunlea et al., 2009) do not suggest a major SOA source in the FT this should not greatly impact our analysis. However, additional information on the vertical profile of OA is important in reduc- ing the uncertainty in the OA budget. Whereas the Zhang et al. (2007) database was limited to the Northern Hemisphere $(\mathrm{NH})$ extra-tropics $\left(19^{\circ} \mathrm{N}\right.$ to $\left.62^{\circ} \mathrm{N}\right)$ our new dataset includes observations both in the Southern Hemisphere and tropics $\left(19^{\circ} \mathrm{S}\right.$ to $\left.62^{\circ} \mathrm{N}\right)$ which as we show below, are important in constraining the global SOA source. Observations from the AMMA and DABEX fields campaigns sample air influenced by tropical biomass burning. As in Zhang et al. (2007) all sites are classified as urban, urban-downwind or rural/remote. In our dataset 21 of the 47 observations are classified as rural/remote. 
Table 2. Continued.

\begin{tabular}{|c|c|c|c|c|c|c|c|c|c|c|}
\hline \multirow[t]{2}{*}{$\#$} & \multirow{2}{*}{$\begin{array}{l}\text { SOA yield }(\mathrm{y}) \text {, } \\
\text { reaction rate } \\
(\mathrm{r}) \text {, and POA } \\
\text { half-life }\left(\tau_{\mathrm{p}}\right)^{\mathrm{a}}\end{array}$} & \multicolumn{6}{|c|}{ Global SOA source $^{\mathrm{b}} / \mathrm{Tg}(\mathrm{SOA}) \mathrm{a}^{-1}$} & \multicolumn{3}{|c|}{ Summary statistics ${ }^{\mathrm{c}}$} \\
\hline & & $S_{\mathrm{M}}$ & $\mathrm{S}_{\mathrm{I}}$ & $\mathrm{S}_{\mathrm{A}}$ & $S_{\mathrm{BB}}$ & $S_{\mathrm{P}}$ & $\begin{array}{l}\mathrm{NMB} / \\
\%\end{array}$ & $\begin{array}{l}\text { NME/ } \\
\%\end{array}$ & $\begin{array}{l}\text { RMSE/ } \\
\mu \mathrm{g} \mathrm{m}^{-3}\end{array}$ & $R^{2}$ \\
\hline 8 & $\begin{array}{l}\mathrm{y} 1-3=26 \% \\
\mathrm{y} 4-6=6 \% \\
\tau_{\mathrm{p}}=1 \text { day }\end{array}$ & 32.3 & 26.2 & 0. & 0. & 39.5 & $\begin{array}{l}-64 \\
(-52)\end{array}$ & $\begin{array}{l}75 \\
(80)\end{array}$ & $3.7(2.4)$ & $\begin{array}{l}0.10 \\
(0.00)\end{array}$ \\
\hline 9 & $\begin{array}{l}\mathrm{y} 1-3=16 \% \\
\mathrm{y} 4-6=6 \% \\
\tau_{\mathrm{p}}=2.7 \text { days }\end{array}$ & 32.3 & 26.2 & 0. & 0. & 32.5 & $\begin{array}{l}-68 \\
(-57)\end{array}$ & $78(83)$ & $3.8(2.4)$ & $\begin{array}{l}0.06 \\
(0.00)\end{array}$ \\
\hline 10 & $\begin{array}{l}\mathrm{y} 1-3=26 \% \\
\mathrm{y} 4-5=6 \% \\
\tau_{\mathrm{p}}=8 \text { days }\end{array}$ & 32.3 & 26.2 & 0. & 0. & 19.5 & $\begin{array}{l}-72 \\
(-63)\end{array}$ & $\begin{array}{l}81 \\
(86)\end{array}$ & $4.0(2.5)$ & $\begin{array}{l}0.02 \\
(0.00)\end{array}$ \\
\hline 11 & $\begin{array}{l}\mathrm{y} 1-3=26 \% \\
\mathrm{y} 4-6=6 \%, \\
\mathrm{y} 7=30 \%\end{array}$ & 32.3 & 26.2 & 38. & 0. & 0. & $\begin{array}{l}-51 \\
(-40)\end{array}$ & $67(77)$ & $3.5(2.1)$ & $\begin{array}{l}0.08 \\
(0.03)\end{array}$ \\
\hline 12 & $\begin{array}{l}y 1-3=26 \% \\
y 4-6=6 \% \\
y 7=60 \%\end{array}$ & 32.3 & 26.2 & 76. & 0. & 0. & $\begin{array}{l}-25 \\
(-10)\end{array}$ & $59(63)$ & $3.2(1.9)$ & $\begin{array}{l}0.13 \\
(0.13)\end{array}$ \\
\hline 13 & $\begin{array}{l}\mathrm{y} 1-3=26 \% \\
\mathrm{y} 7=30 \%\end{array}$ & 32.3 & 0. & 38. & 0 . & 0. & $\begin{array}{l}-59 \\
(-50)\end{array}$ & $68(72)$ & $3.6(2.1)$ & $\begin{array}{l}0.10 \\
(0.09)\end{array}$ \\
\hline 14 & $\begin{array}{l}\mathrm{y} 1-3=26 \% \\
\mathrm{y} 7=60 \%\end{array}$ & 32.3 & 0. & 76. & 0. & 0. & $\begin{array}{l}-33 \\
(-20)\end{array}$ & $55(58)$ & $3.2(1.7)$ & $\begin{array}{l}0.16 \\
(0.21)\end{array}$ \\
\hline 15 & $\begin{array}{l}\mathrm{y} 1-3=26 \% \\
\mathrm{y} 7=90 \%\end{array}$ & 32.3 & 0. & 114. & 0. & 0. & $\begin{array}{l}-8 \\
(9)\end{array}$ & $57(52)$ & $3.0(1.7)$ & $\begin{array}{l}0.19 \\
(0.29)\end{array}$ \\
\hline 16 & $\mathrm{y} 7=90 \%$ & 0.0 & 0. & 114. & 0. & 0. & $\begin{array}{l}-23 \\
(-10)\end{array}$ & $50(41)$ & $2.9(1.3)$ & $\begin{array}{l}0.25 \\
(0.51)\end{array}$ \\
\hline 17 & $\begin{array}{l}\mathrm{y} 1-3=26 \% \\
\mathrm{y} 4-5=6 \%, \\
\mathrm{y} 7=30 \%, \\
\mathrm{y} 8=90 \%\end{array}$ & 32.3 & 26.2 & 38. & 42.3 & 0. & $\begin{array}{l}-45 \\
(-30)\end{array}$ & $64(73)$ & $3.4(2.1)$ & $\begin{array}{l}0.11 \\
(0.04)\end{array}$ \\
\hline 18 & $\begin{array}{l}\text { y1-3=26\%, } \\
\text { y7 }=30 \%, \\
\text { r7 }=10\end{array}$ & 32.3 & 0. & 38.8 & 0. & 0. & $\begin{array}{l}-50 \\
(-44)\end{array}$ & $\begin{array}{l}60 \\
(70)\end{array}$ & $3.5(2.0)$ & $\begin{array}{l}0.10 \\
(0.10)\end{array}$ \\
\hline
\end{tabular}

\subsection{Additional organic carbon observations}

As an independent test of our estimated SOA sources we also compared the model against organic carbon (OC) observations compiled by Bahadur et al. (2009). This work compiled ground-based measurements of OC in fine particles $\left(\mathrm{PM}_{2.5}\right.$, mass of particulate matter with diameter less than $2.5 \mu \mathrm{m}$ ). The dataset represents observations from around the world but is dominated by observations across North America with substantially fewer observations available from the rest of the world. In the United States observations were compiled from continuous monitoring networks including the Interagency Monitoring of Protected Visual Environments (IMPROVE) (Malm et al., 1994), Southeastern Aerosol Re- search and Characterization Study (SEARCH) (Hansen et al., 2003), North American Research Strategy for Tropospheric Ozone (NARSTO), California Regional PM10/PM2.5 Air Quality Study (CRPAQS) (Chow et al., 2006), New England Air Quality Study (NEAQS) and the Speciated Trends Network (STN) administered by the Environmental Protection Agency (EPA) (available through the Air Quality System, (AQSEPA) data repository). Across Europe observations were compiled from the European Monitoring and Evaluation Programme (EMEP) and the Construction, Use and Delivery of a European Aerosol Database (CREATE). Observations were also compiled from the peer-reviewed literature across North America, Europe and Asia. 
Table 2. Continued.

\begin{tabular}{|c|c|c|c|c|c|c|c|c|c|c|}
\hline \multirow[t]{2}{*}{ \# } & \multirow{2}{*}{$\begin{array}{l}\text { SOA yield }(y) \text {, } \\
\text { reaction rate } \\
(\mathrm{r}) \text {, and } \mathrm{POA} \\
\text { half-life }\left(\tau_{\mathrm{p}}\right)^{\mathrm{a}}\end{array}$} & \multicolumn{6}{|c|}{ Global SOA source ${ }^{b} / \operatorname{Tg}(\mathrm{SOA}) \mathrm{a}^{-1}$} & \multicolumn{3}{|c|}{ Summary statistics ${ }^{\mathrm{c}}$} \\
\hline & & $S_{\mathrm{M}}$ & $\mathrm{S}_{\mathrm{I}}$ & $\mathrm{S}_{\mathrm{A}}$ & $S_{\mathrm{BB}}$ & $S_{\mathrm{P}}$ & $\begin{array}{l}\mathrm{NMB} / \\
\%\end{array}$ & $\begin{array}{l}\text { NME/ } \\
\%\end{array}$ & $\begin{array}{l}\text { RMSE/ } \\
\mu \mathrm{g} \mathrm{m}^{-3}\end{array}$ & $R^{2}$ \\
\hline 19 & $\begin{array}{l}\mathrm{y} 1-3=26 \% \\
\mathrm{y} 7=60 \% \\
\mathrm{r} 7=10\end{array}$ & 32.3 & 0. & 77.6 & 0. & 0. & $\begin{array}{l}-15 \\
(-8)\end{array}$ & $\begin{array}{l}60 \\
(60)\end{array}$ & $3.2(1.8)$ & $\begin{array}{l}0.14 \\
(0.20)\end{array}$ \\
\hline 20 & $\begin{array}{l}\mathrm{y} 1-3=26 \% \\
\mathrm{y} 7=90 \% \\
\mathrm{r} 7=10\end{array}$ & 32.3 & 0. & 116. & 0. & 0. & $\begin{array}{l}20 \\
(27)\end{array}$ & $\begin{array}{l}75 \\
(64)\end{array}$ & $3.5(2.2)$ & $\begin{array}{l}0.16 \\
(0.25)\end{array}$ \\
\hline 21 & $\begin{array}{l}\mathrm{y} 1-3=26 \% \\
\mathrm{y} 7=30 \% \\
\mathrm{r} 7=100\end{array}$ & 32.3 & 0. & 39. & 0. & 0. & $\begin{array}{l}-42 \\
(-40)\end{array}$ & $\begin{array}{l}61 \\
(69)\end{array}$ & $3.4(2.0)$ & $\begin{array}{l}0.09 \\
(0.09)\end{array}$ \\
\hline 22 & $\begin{array}{l}\mathrm{y} 1-3=26 \% \\
\mathrm{y} 7=60 \% \\
\mathrm{r} 7=100\end{array}$ & 32.3 & 0. & 78. & 0. & 0. & $\begin{array}{l}1 \\
(1)\end{array}$ & $\begin{array}{l}71 \\
(64)\end{array}$ & $3.4(2.0)$ & $\begin{array}{l}0.12 \\
(0.17)\end{array}$ \\
\hline 23 & $\begin{array}{l}\mathrm{y} 1-3=26 \% \\
\mathrm{y} 7=90 \% \\
\mathrm{r} 7=100\end{array}$ & 32.3 & 0. & 117. & 0. & 0. & $\begin{array}{l}44 \\
(42)\end{array}$ & $\begin{array}{l}93 \\
(78)\end{array}$ & $4.4(2.7)$ & $\begin{array}{l}0.12 \\
(0.21)\end{array}$ \\
\hline 24 & $\begin{array}{l}\mathrm{y} 1-2=26 \% \\
\mathrm{y} 3=130 \%\end{array}$ & 104.8 & 0.0 & 0. & 0. & 0. & $\begin{array}{l}-50 \\
(-36)\end{array}$ & $\begin{array}{l}85 \\
(105)\end{array}$ & 4.1(2.9) & $\begin{array}{l}0.00 \\
(0.02)\end{array}$ \\
\hline 25 & $\begin{array}{l}\mathrm{y} 1,3=26 \% \\
\mathrm{y} 2=130 \%\end{array}$ & 44.9 & 0.0 & 0. & 0. & 0. & $\begin{array}{l}-78 \\
(-71)\end{array}$ & $\begin{array}{l}85 \\
(89)\end{array}$ & $4.2(2.7)$ & $\begin{array}{l}0.00 \\
(0.01)\end{array}$ \\
\hline 26 & $\begin{array}{l}\mathrm{y} 1=130 \% \\
\mathrm{y} 2-3=36 \%\end{array}$ & 53.4 & 0.0 & 0. & 0. & 0. & $\begin{array}{l}-65 \\
(-55)\end{array}$ & $\begin{array}{l}83 \\
(96)\end{array}$ & $4.1(2.7)$ & $\begin{array}{l}0.00 \\
(0.02)\end{array}$ \\
\hline 27 & $\begin{array}{l}\mathrm{y} 1-\mathrm{y} 3=26 \% \\
\mathrm{y} 10=130 \% \\
\mathrm{r} 10=1\end{array}$ & 39.6 & 0.0 & 0. & 0. & 0. & $\begin{array}{l}-73 \\
(-70)\end{array}$ & $\begin{array}{l}81 \\
(88)\end{array}$ & $4.1(2.6)$ & $\begin{array}{l}0.01 \\
(0.00)\end{array}$ \\
\hline 28 & $\begin{array}{l}\mathrm{y} 1-\mathrm{y} 3=26 \% \\
\mathrm{y} 10=130 \% \\
\mathrm{r} 10=10\end{array}$ & 63.4 & 0.0 & 0. & 0. & 0. & $\begin{array}{l}-50 \\
(-44)\end{array}$ & $\begin{array}{l}80 \\
(97)\end{array}$ & $4.0(2.9)$ & $\begin{array}{l}0.00 \\
(0.00)\end{array}$ \\
\hline 29 & $\begin{array}{l}\mathrm{y} 1-3=26 \% \\
\mathrm{y} 4-6=6 \% \\
\mathrm{r} 9=1, \\
\mathrm{y} 9=100 \%\end{array}$ & 63 & & 0. & 0. & 0. & $\begin{array}{l}-71 \\
(-65)\end{array}$ & $\begin{array}{l}82 \\
(92)\end{array}$ & $4.1(2.7)$ & $\begin{array}{l}0.00 \\
(0.02)\end{array}$ \\
\hline
\end{tabular}

Bahadur et al. (2009) describes the measurement techniques in detail. Briefly, particles are collected onto quartz filters and $\mathrm{OC}$ concentrations obtained using the evolved gas analysis method. The collection of particles by filter can result in artifacts in reported OC concentrations (Turpin et al., 2000). Adsorption of gas phase organics onto the filter can result in positive artifacts of between $15-50 \%$ whereas volatilization of particulate matter from the filter can lead to negative artifacts of up to $80 \%$ (see Bahadur et al., 2009). The minimum detection limit of this method is estimated as $50 \mathrm{ng} \mathrm{m}^{-3}$ and a overall uncertainty of up to $100 \%$ (Bahadur et al., 2009).
For observations from the IMPROVE network we calculate monthly mean OC concentrations for the year 2000, which is the year simulated by the model. For all other sites from the Bahadur et al. (2009) dataset we calculate a climatological monthly mean OC concentration. We linearly interpolated monthly mean model output to the location of the observations. Bahadur et al. (2009) do not include information on the elevation of observation locations. We therefore use the surface model level for comparison, except for IMPROVE where we use information on the elevation of the sites (available from IMPROVE) and sample the appropriate model level. This method is most appropriate for the IMPROVE network which includes many sites in the 
Table 2. Continued.

\begin{tabular}{|c|c|c|c|c|c|c|c|c|c|c|}
\hline \multirow[t]{2}{*}{ \# } & \multirow{2}{*}{$\begin{array}{l}\text { SOA yield }(\mathrm{y}) \text {, } \\
\text { reaction rate } \\
(\mathrm{r}) \text {, and POA } \\
\text { half-life }\left(\tau_{\mathrm{p}}\right)^{\mathrm{a}}\end{array}$} & \multicolumn{6}{|c|}{ Global SOA source $^{\mathrm{b}} / \mathrm{Tg}(\mathrm{SOA}) \mathrm{a}^{-1}$} & \multicolumn{3}{|c|}{ Summary statistics ${ }^{c}$} \\
\hline & & $S_{\mathrm{M}}$ & $\mathrm{S}_{\mathrm{I}}$ & $\mathrm{S}_{\mathrm{A}}$ & $S_{\mathrm{BB}}$ & $S_{\mathrm{P}}$ & $\begin{array}{l}\mathrm{NMB} / \\
\%\end{array}$ & $\begin{array}{l}\text { NME/ } \\
\%\end{array}$ & $\begin{array}{l}\text { RMSE/ } \\
\mu \mathrm{g} \mathrm{m}^{-3}\end{array}$ & $R^{2}$ \\
\hline 30 & $\begin{array}{l}\mathrm{y} 1-3=26 \% \\
\mathrm{y} 4-6=6 \% \\
\mathrm{r} 9=10 \\
\mathrm{y} 9=100 \%\end{array}$ & & & 0. & 0. & 0. & $\begin{array}{l}-32 \\
(-25)\end{array}$ & $\begin{array}{l}87 \\
(105)\end{array}$ & $4.0(3.1)$ & $\begin{array}{l}0.02 \\
(0.00)\end{array}$ \\
\hline 31 & $\begin{array}{l}\mathrm{y} 1-3=26 \% \\
\mathrm{y} 4-6=6 \%, \\
\mathrm{r} 9=10 \\
\mathrm{y} 9=50 \%\end{array}$ & & & 0. & 0. & 0. & $\begin{array}{l}-54 \\
(-48)\end{array}$ & $\begin{array}{l}80 \\
(96)\end{array}$ & $3.9(2.7)$ & $\begin{array}{l}0.01 \\
(0.00)\end{array}$ \\
\hline 32 & $\begin{array}{l}\mathrm{y} 1-3=26 \% \\
\mathrm{y} 4-6=6 \% \\
\mathrm{r} 9=10 \\
\mathrm{y} 9=20 \%\end{array}$ & & & 0. & 0 . & 0. & $\begin{array}{l}-68 \\
(-62)\end{array}$ & $\begin{array}{l}81 \\
(93)\end{array}$ & $4.0(2.7)$ & $\begin{array}{l}0.00 \\
(0.01)\end{array}$ \\
\hline 33 & $\begin{array}{l}\text { Optimised } \\
\text { yields }\end{array}$ & 6.5 & 6.5 & 100. & 3. & 23. & $\begin{array}{l}-11 \\
(5)\end{array}$ & $\begin{array}{l}53 \\
(46)\end{array}$ & $2.9(1.5)$ & $\begin{array}{l}0.23 \\
(0.37)\end{array}$ \\
\hline 34 & $\begin{array}{l}\text { Optimised } \\
\text { yields }\end{array}$ & 195. & 6.5 & 10. & 3. & 23. & $\begin{array}{l}4 \\
(33)\end{array}$ & $\begin{array}{l}101 \\
(133)\end{array}$ & $4.7(4.3)$ & $\begin{array}{l}0.06 \\
(0.01)\end{array}$ \\
\hline \multicolumn{11}{|c|}{ Comparison against observed HOA } \\
\hline 1 & N/A & N/A & N/A & N/A & N/A & N/A & $\begin{array}{l}-16 \\
(274)\end{array}$ & $\begin{array}{l}85 \\
(274)\end{array}$ & $1.4(1.1)$ & $\begin{array}{l}0.27 \\
(0.65)\end{array}$ \\
\hline 8 & $\tau_{\mathrm{p}}=1$ day & N/A & N/A & N/A & N/A & 39.5 & $\begin{array}{l}-60 \\
(45)\end{array}$ & $73(73)$ & $1.5(0.25)$ & $\begin{array}{l}0.41 \\
(0.71)\end{array}$ \\
\hline 9 & $\tau_{\mathrm{p}}=2.7$ days & N/A & N/A & N/A & N/A & 32.5 & $\begin{array}{l}-46 \\
(114)\end{array}$ & $\begin{array}{l}74 \\
(122)\end{array}$ & $1.4(0.5)$ & $\begin{array}{l}0.37 \\
(0.70)\end{array}$ \\
\hline 10 & $\tau_{\mathrm{p}}=8$ days & N/A & N/A & N/A & N/A & 17.5 & $\begin{array}{l}-31 \\
(190)\end{array}$ & $\begin{array}{l}78 \\
(194)\end{array}$ & $1.4(0.8)$ & $\begin{array}{l}0.31 \\
(0.67)\end{array}$ \\
\hline
\end{tabular}

\footnotetext{
${ }^{a}$ Reactions specified in Table 1. SOA yields (y1-y10) are defined as the SOA mass formed as a fraction of the emitted VOC mass expressed as a percentage. They are specified when they are non-zero. In simulations $16-18$ POA is aged to SOA assuming a first order rate constant. We specify the half life ( $\tau_{\mathrm{p}}$ ) of POA with respect to ageing to SOA.

${ }^{\mathrm{b}}$ Conversion factor of $2 \mathrm{Tg}(\mathrm{SOA}): 1 \mathrm{Tg}(\mathrm{C})$.

${ }^{\mathrm{c}}$ Normalised mean bias $(\mathrm{NMB})=100 \% \times \sum\left(M_{i}-O_{i}\right) / \sum \mathrm{O}_{i}$; normalised mean error $(\mathrm{NME})=100 \% \times \sum\left|M_{i}-O_{i}\right| / \sum O_{i}$; root mean square error $(\mathrm{RMSE})$

$=\left[1 / \mathrm{N} \sum\left(M_{i}-O_{i}\right)^{2}\right]^{1 / 2}$ and correlation coefficient $\left(R^{2}\right)$ between model $\left(M_{i}\right)$ and observations $\left(O_{i}\right)$ where $i$ represents a given study in the AMS dataset.
}

mountainous western United States. Comparison with the global model is described in Sect. 3.5.

\section{Results}

\subsection{Global model simulations}

For each of the global model simulations in Table 2 we spatially and temporally interpolated monthly mean component-resolved aerosol mass concentrations to the location and time period of the AMS observations. Table 2 summarises normalised mean bias (NMB), normalised mean error (NME), root mean square error (RMSE) and correlation coefficient $\left(r^{2}\right)$ between model and observations. We also make comparisons against a sub-set of the AMS dataset for those sites that had been identifed as remote. We do this to ensure that our comparisons are not biased by urban-scale pollution that is not resolved by our relatively coarse resolution global model. Figure 2 shows sulfate, OA, HOA and OOA observed by the AMS against the standard version of the global model (simulation 1, SOA from monoterpenes only). The model reasonably captures the observed distribution of sulfate $\left(\mathrm{NMB}=18 \%, \quad \mathrm{NME}=66 \%, \quad \mathrm{RMSE}=3.0 \mu \mathrm{g} \mathrm{m}^{-3}\right.$, $\left.r^{2}=0.36\right)$ but underpredicts $\mathrm{OA} \quad(\mathrm{NMB}=-68 \%$, $\left.\mathrm{NME}=74 \%, \quad \mathrm{RMSE}=5.1 \mu \mathrm{g} \mathrm{m}^{-3}, \quad r^{2}=0.27\right), \quad \mathrm{HOA}$ 
Table 3. Summary of the location, time and duration of the AMS studies, additional to those described in Zhang et al. (2007), that were used in our analysis. All additional sites were classified as remote.

\begin{tabular}{|c|c|c|c|c|c|c|c|}
\hline Dataset name & Location & Lon. & Lat. & $\begin{array}{l}\text { Elevation } \\
(\mathrm{m})\end{array}$ & Time Period & Season & $\begin{array}{l}\text { Previous publications/ } \\
\text { Acknowledgments }\end{array}$ \\
\hline OP3 & Bukit Atur, Sabah, Malaysia & 117.8 & 5.0 & 426 & 06/21/2008-07/24/2008 & Wet & $\begin{array}{l}\text { Hewitt et al. (2010); } \\
\text { Robinson et al. (2011) }\end{array}$ \\
\hline Whistler & Whistler Peak, BC, Canada & -122.9 & 50.0 & 2181 & 04/20/2006-05/17/2006 & Summer & Sun et al. (2009) \\
\hline Trinidad Head & Trinindad Head, CA, USA & -124.1 & 41.1 & 107 & 04/20/2002-05/20/2002 & Summer & Allan et al. (2004) \\
\hline VOCALS & Southeast Pacific & -72.5 & -18.9 & 413 & $10 / 14 / 2008-11 / 13 / 2008$ & & $\begin{array}{l}\text { K. Demerijan ASRC, UAlbany } \\
\text { Yin-Nan Lee \& L. Kleinman, } \\
\text { Brookhaven National Laboratory }\end{array}$ \\
\hline AMMA & West Africa & 2.2 & 13.5 & $<2000$ & 07/17/2008-08/18/2008 & & Capes et al. (2009) \\
\hline DABEX & West Africa & 4.0 & 13.0 & $<2000$ & $01 / 13 / 2006-02 / 03 / 2006$ & & Capes et al. (2008) \\
\hline DABEX & West Africa & -17.0 & 12.0 & $<2000$ & 01/13/2006-02/03/2006 & & Capes et al. (2008) \\
\hline
\end{tabular}

(a)

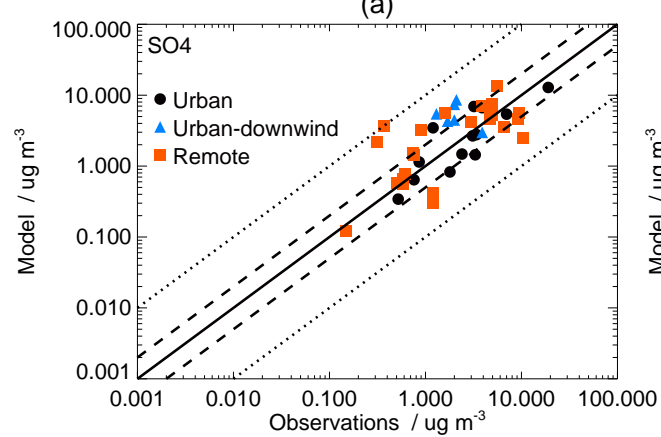

(c)

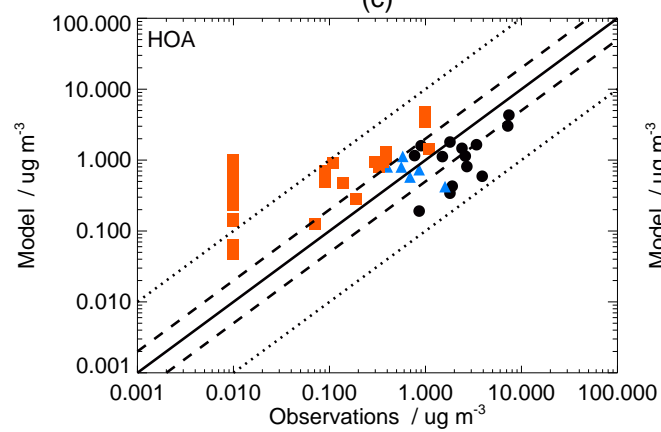

(b)

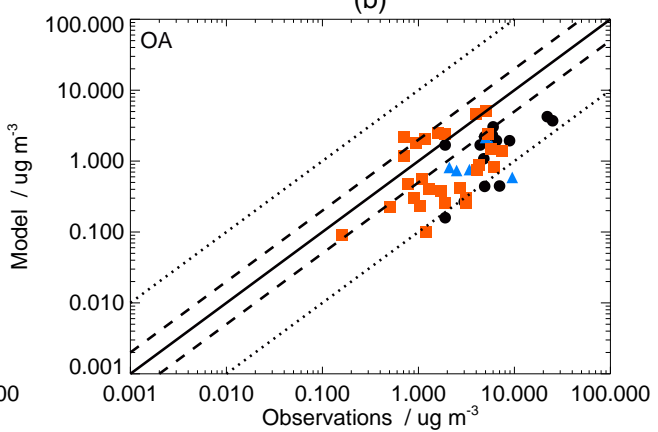

(d)

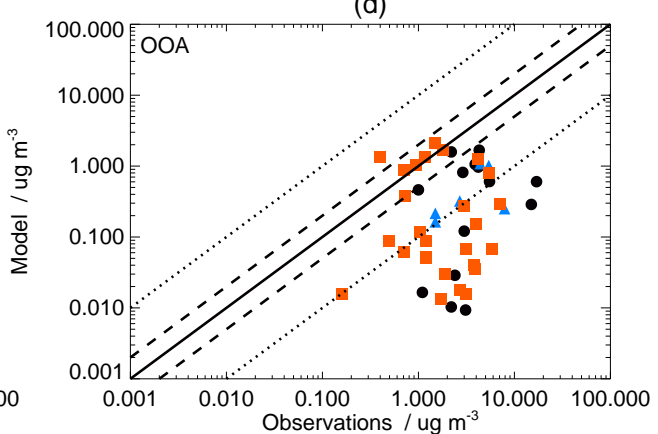

Fig. 2. Scatterplot of simulated (GLOMAP, simulation 1) versus observed (AMS) (a) sulfate, (b) OA, (c) HOA and (d) OOA. Model includes SOA from monoterpenes (26\% SOA yield, $\left.32.3 \mathrm{Tg}(\mathrm{SOA}) \mathrm{a}^{-1}\right)$. Observation locations are classified as urban, urban-downwind and rural/remote as in Zhang et al. (2007). The 1:1 line (solid), 2:1 lines (dashed) and 10:1 lines (dotted) are indicated. Model-observation statistics are shown in Table 2. Observational constraints limit identification of HOA at very low concentrations. We assume a lower limit for HOA of $0.01 \mu \mathrm{g} \mathrm{m}^{-3}$.

$\left(\mathrm{NMB}=-16 \%, \quad \mathrm{NME}=85 \%, \quad \mathrm{RMSE}=1.4 \mu \mathrm{g} \mathrm{m}^{-3}\right.$, $\left.r^{2}=0.27\right)$ and $\mathrm{OOA} \quad(\mathrm{NMB}=-85 \%, \quad \mathrm{NME}=87 \%$, $\mathrm{RMSE}=4.3 \mu \mathrm{g} \mathrm{m}^{-3}$ ) concentrations and has no skill in capturing the spatial or temporal pattern of OOA $\left(r^{2}=0.0\right)$. Model underprediction of HOA is driven by an under- prediction at urban locations, most likely because the spatial resolution of the global model is too coarse to resolve urban-scale pollution. The model overpredicts HOA at remote locations which we discuss below. The model generally underpredicts both $\mathrm{OA}(\mathrm{NMB}=-51 \%)$ 
and $\mathrm{OOA}(\mathrm{NMB}=-80 \%)$ at remote sites although $\mathrm{OOA}$ concentrations at some remote sites (e.g., Central Amazon (AMAZE), north-eastern North America (White Face Mountain, Chebogue Point), West Africa (AMMA)) are reasonably simulated (within a factor 2 ).

We completed 5 sets of simulations where we varied the SOA formation from the 5 different sources as described in Sect. 2.2. We tested each simulation against observed concentrations of OOA using NME, RMSE and $r^{2}$ as an indicator of model skill. First, we modified the source of SOA from isoprene and monoterpenes (Fig. 3). Increasing the source of SOA from monoterpenes (simulations 23 ) or isoprene (simulations 4-5) reduces the model bias but does not improve model skill. For example, the model simulation where we increased the SOA yield from monoterpenes to $130 \%$, from $26 \%$ in the standard simulation, resulting in a global SOA source of $161.5 \mathrm{Tg}(\mathrm{SOA}) \mathrm{a}^{-1}$, reduces the bias (NMB $=-24 \%$ ) but model skill is not improved $\left(\mathrm{NME}=94 \%, \mathrm{RMSE}=4.3 \mu \mathrm{g} \mathrm{m}^{-3}, r^{2}=0.0\right)$. Further increasing the SOA yield from monoterpenes to $198 \%$, resulting in a global SOA source of $246 \mathrm{Tg}$ (SOA) $\mathrm{a}^{-1}$, results in an overprediction of SOA on average across all the sites $(\mathrm{NMB}=16 \%)$ and unimproved model skill $(\mathrm{NME}=118 \%$, $\left.\mathrm{RMSE}=5.3 \mu \mathrm{g} \mathrm{m}{ }^{-3}, r^{2}=0.0\right) . \quad$ These simulations suggest that a monoterpene SOA source of $\sim 210 \mathrm{Tg}(\mathrm{SOA}) \mathrm{a}^{-1}$ would be sufficient to match the average magnitude of the AMS observations (i.e., reduce mean model bias to zero), but would not improve model skill. Similarly, including SOA from isoprene (assuming an SOA yield of $6 \%$ or $12 \%$ ) reduces the model bias $(\mathrm{NMB}=-77 \%$ and $=-68 \%$ respectively) but does not improve model skill (NME $=85 \%$, $\mathrm{RMSE}=4.3 \mu \mathrm{g} \mathrm{m}^{-3}, r^{2}=0.0$ ). These results suggest that an increase of biogenic SOA alone is unable to explain the spatial and temporal patterns in the global OOA observations and additional SOA sources with a different spatial and temporal behaviour must exist to explain the observations.

In the second set of experiments (simulations 6-7) we included an additional SOA source from biomass burning (Fig. 4), which in the baseline run was set to zero. Assuming an SOA yield of $90 \%$ from biomass burning VOCs (simulation 6), resulting in an SOA source of $42.3 \mathrm{Tg}(\mathrm{SOA}) \mathrm{a}^{-1}$, leads to a reduction in model bias $(\mathrm{NMB}=-71 \%)$ and improves model skill $(\mathrm{NME}=81 \%$, $\left.\mathrm{RMSE}=4.0 \mu \mathrm{g} \mathrm{m}^{-3}, r^{2}=0.03\right)$. However, further increasing the SOA yield from biomass burning VOCs to $180 \%$ (simulation 7, 84.6 $\mathrm{Tg}(\mathrm{SOA}) \mathrm{a}^{-1}$ ) resulted in no further reduction in model error $\left(\mathrm{NME}=82 \%, \mathrm{RMSE}=3.9 \mu \mathrm{g} \mathrm{m}^{-3}\right.$, $\left.r^{2}=0.03\right)$.

The third set of experiments (simulations 8-10) tests the effect of an additional source of OOA through oxidation of POA. At remote sites, where observed HOA concentrations were below the detection limit, the baseline model overpredicts HOA concentrations ( $\mathrm{NMB}=274 \%$ ). This overprediction could be due to homogeneous or heterogeneous oxidation of HOA to OOA that is not treated in the baseline simu- lations, underprediction of HOA removal by wet or dry deposition, or the uncertainty in accurately extracting a small fraction of HOA from AMS spectra dominated by OOA (Zhang et al., 2007; Ulbrich et al., 2009). Previous studies suggest an HOA to OOA heterogeneous oxidation timescale of several days (Petters et al., 2007; George and Abbatt, 2010). When we simulate such an ageing by converting POA to SOA assuming a fixed lifetime, HOA model bias is reduced at remote sites, with a minimum bias calculated for an oxidation timescale of $24 \mathrm{~h}$ (simulation $8, \mathrm{NMB}=45 \%$ ). Including this ageing also improves simulated OOA: with a POA to OOA source of $19.5 \mathrm{Tg}$ (SOA) $\mathrm{a}^{-1}$ (simulation 10) model bias is reduced $(\mathrm{NMB}=-72 \%)$ and the model error is slightly improved $\left(\mathrm{NME}=81 \%, \mathrm{RMSE}=4.0 \mu \mathrm{g} \mathrm{m}^{-3}\right.$, $r^{2}=0.02$ ). This is similar to the results using a biomass burning SOA source of the same magnitude, as most POA in the model is due to biomass burning emissions. Further increasing the POA to OOA source to $39.5 \mathrm{Tg}(\mathrm{SOA}) \mathrm{a}^{-1}$ (simulation 8) further reduces model error and improves the correlation coefficient $\left(\mathrm{NME}=75 \%, \mathrm{RMSE}=3.7 \mu \mathrm{g} \mathrm{m} \mathrm{m}^{-3}\right.$, $\left.r^{2}=0.10\right)$.

The fourth set of experiments (simulations 11-23) investigated the effect of including a source of SOA linked to anthropogenic CO emissions ("anthropogenically controlled"). These experiments lead to an improved simulation of OOA. When we assume an SOA yield of $30 \%$ from anthropogenic VOCs, resulting in $38 \mathrm{Tg}(\mathrm{SOA}) \mathrm{a}^{-1}$ from this source (simulation 13), the model has reduced bias and improved model skill $(\mathrm{NMB}=-59 \%, \mathrm{NME}=68 \%, \mathrm{RMSE}=3.6 \mu \mathrm{g}$ $\left.\mathrm{m}^{-3}, r^{2}=0.1\right)$. When the SOA yield from anthropogenic VOCs is increased to $60 \%\left(76 \mathrm{Tg}(\mathrm{SOA}) \mathrm{a}^{-1}\right.$, simulation 14) model bias is further reduced and mode skill further improved $\left(\mathrm{NMB}=-33 \%, \mathrm{NME}=55 \%, \mathrm{RMSE}=3.2 \mu \mathrm{g} \mathrm{m}^{-3}\right.$, $\left.r^{2}=0.16\right)$. Model bias is also reduced at remote sites $(\mathrm{NMB}=-20 \%)$ indicating that the improved agreement against the AMS dataset is not being driven by solely by improvement at polluted sites. We tested whether the agreement between model and observations was sensitive to our assumed reaction rate of $\mathrm{VOC}_{\mathrm{A}}$ with $\mathrm{OH}$ (simulations 18-23). Increasing this rate of reaction tends to worsen model skill. For example, when we assume an SOA yield of $60 \%$ (simulation $14, \mathrm{NME}=55 \%, r^{2}=0.16$ ), increasing this rate of reaction (in an otherwise identical model experiment to simulation 14) by a factor of 10 (simulation $19, \mathrm{NME}=60 \%$, $\left.r^{2}=0.14\right)$ and $100\left(\right.$ simulation $22, \mathrm{NME}=71 \%, r^{2}=0.12$ ). For the rest of this work we therefore used the standard reaction rate between $\mathrm{VOC}_{\mathrm{A}}$ and $\mathrm{OH}$ (Table 1).

Finally, in the fifth set of experiments (simulations 2432) we examined a number of simple mechanisms to parameterize a possible enhancement of biogenic SOA by anthropogenic pollution. We found that there was no improvement in model skill when we increased the monoterpene SOA yield to $130 \%$ individually for reaction with $\mathrm{NO}_{3}$ (simulation 24, NME $=85 \%, \mathrm{RMSE}=4.1 \mu \mathrm{g} \mathrm{m}{ }^{-3}$, $\left.r^{2}=0.0\right), \mathrm{O}_{3}$ (simulation $25, \mathrm{NME}=85 \%, \mathrm{RMSE}=4.2 \mu \mathrm{g}$ 
(a)

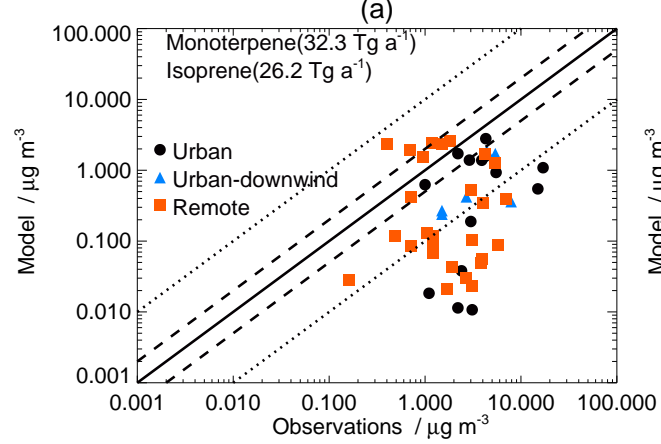

(c)

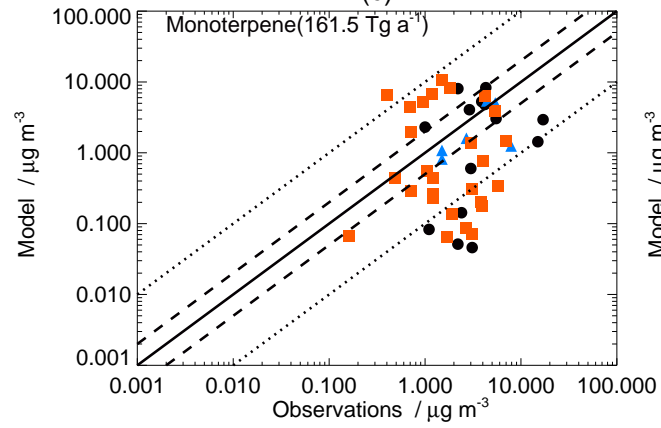

(b)

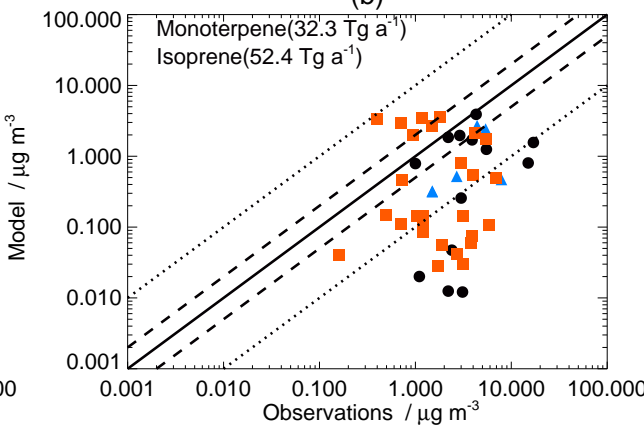

(d)

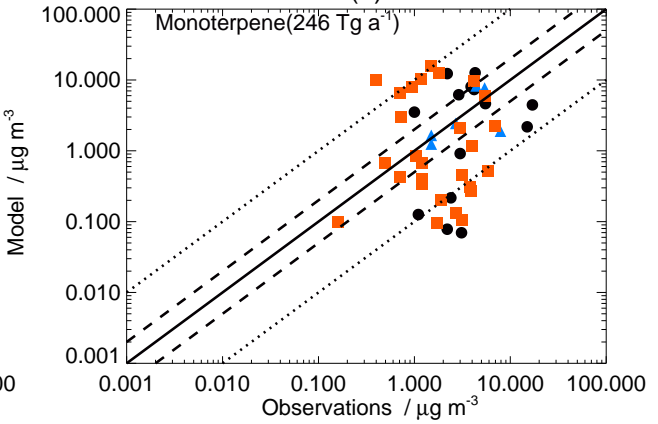

Fig. 3. As for Fig. 2 but for simulated versus observed OOA for (a) simulation 4: monoterpene (32.3 Tg (SOA) $\left.\mathrm{a}^{-1}\right)$, isoprene $\left(26.2 \mathrm{Tg}(\mathrm{SOA}) \mathrm{a}^{-1}\right)$; (b) simulation 5: monoterpene $\left(32.3 \mathrm{Tg}(\mathrm{SOA}) \mathrm{a}^{-1}\right)$, isoprene $\left(52.4 \mathrm{Tg}(\mathrm{SOA}) \mathrm{a}^{-1}\right)$; (c) simulation 2 : monoterpene (161.5 Tg (SOA) $\left.\mathrm{a}^{-1}\right)$; (d) simulation 3: monoterpene (246. $\left.\mathrm{Tg}(\mathrm{SOA}) \mathrm{a}^{-1}\right)$.

(a)

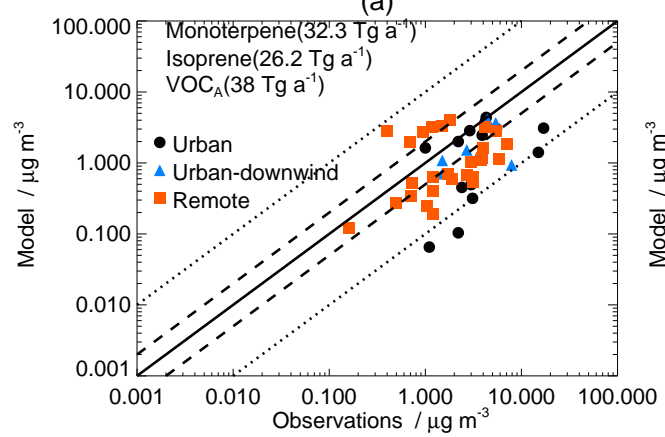

(c)

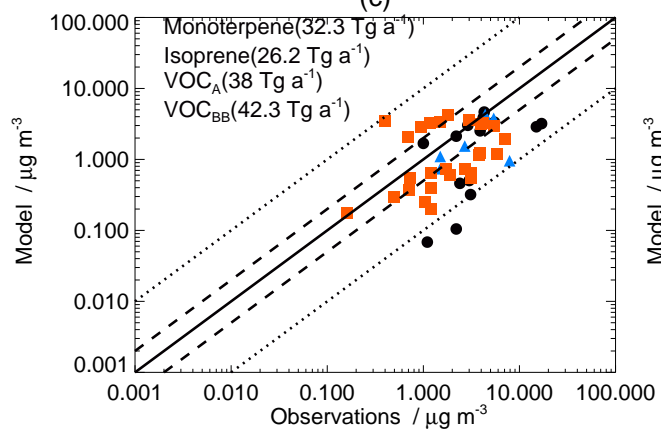

(b)

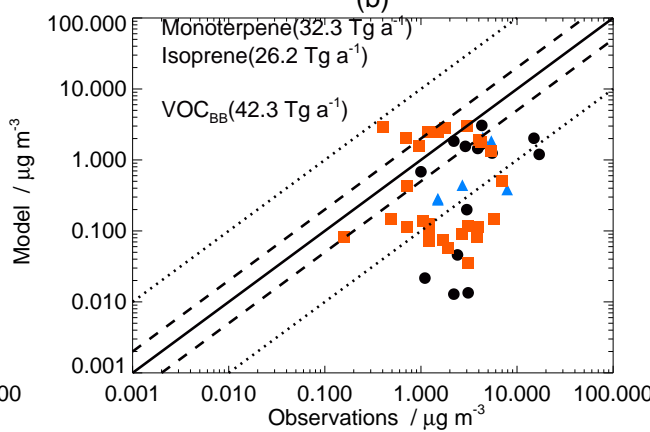

(d)

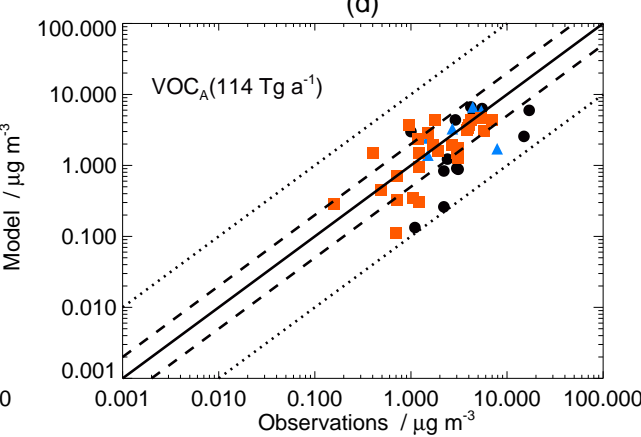

Fig. 4. As for Fig. 3. but for (a) simulation 11: monoterpene $\left(32.3 \mathrm{Tg}(\mathrm{SOA}) \mathrm{a}^{-1}\right)$, isoprene $\left(26.2 \mathrm{Tg}(\mathrm{SOA}) \mathrm{a}^{-1}\right)$, anthropogenic VOC (38. $\left.\operatorname{Tg}(\mathrm{SOA}) \mathrm{a}^{-1}\right)$; (b) simulation 6: monoterpene $\left(32.3 \mathrm{Tg}(\mathrm{SOA}) \mathrm{a}^{-1}\right)$, isoprene $\left(26.2 \mathrm{Tg}(\mathrm{SOA}) \mathrm{a}^{-1}\right)$, biomass burning VOC $\left(42.3 \mathrm{Tg}(\mathrm{SOA}) \mathrm{a}^{-1}\right)$; (c) simulation 17: monoterpene $\left(32.3 \mathrm{Tg}(\mathrm{SOA}) \mathrm{a}^{-1}\right)$, isoprene $\left(26.2 \mathrm{Tg}(\mathrm{SOA}) \mathrm{a}^{-1}\right)$, anthropogenic VOC (38. $\left.\mathrm{Tg}(\mathrm{SOA}) \mathrm{a}^{-1}\right)$, biomass burning VOC $\left(42.3 \mathrm{Tg}(\mathrm{SOA}) \mathrm{a}^{-1}\right)$; (d) simulation 15: anthropogenic VOC $\left(114 . \mathrm{Tg}(\mathrm{SOA}) \mathrm{a}^{-1}\right)$. 
(a)

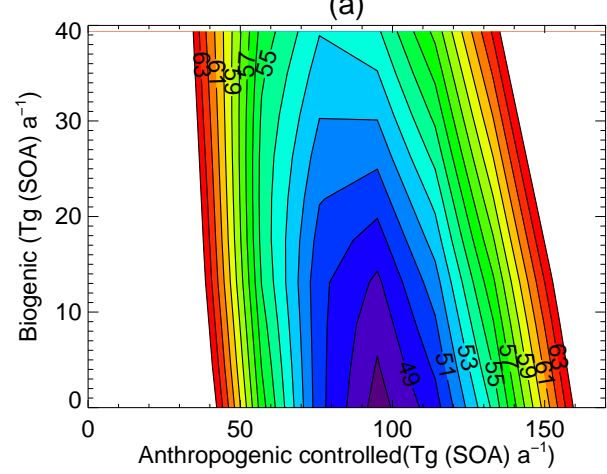

(c)

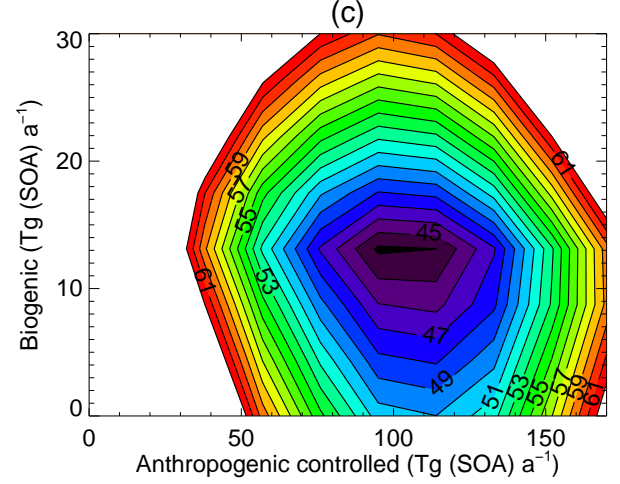

(b)

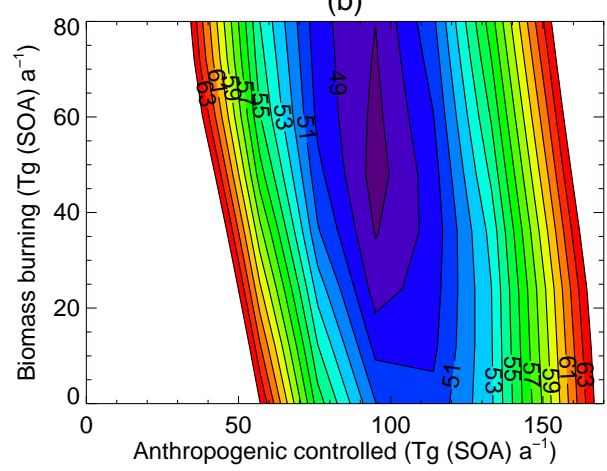

(d)

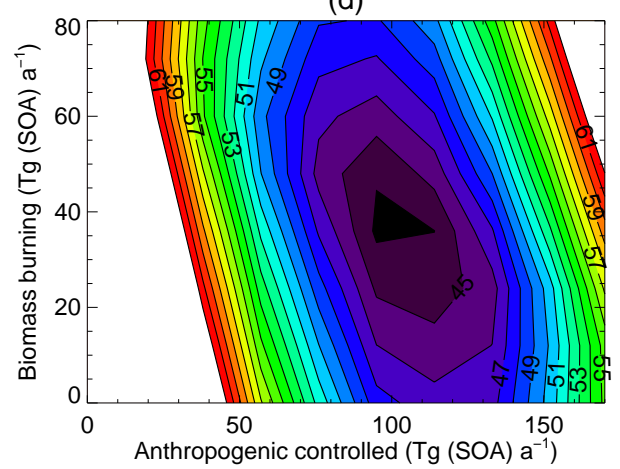

Fig. 5. Normalised mean error (NME, \%) between SOA simulated by a linear version of the global model and OOA observed by the AMS as a function of (a) and (c) biogenic (isoprene and monoterpene) and anthropogenically controlled SOA (biomass burning SOA fixed at $\left.36 \mathrm{Tg}(\mathrm{SOA}) \mathrm{a}^{-1}\right)$; (b) and (d) biomass burning and anthropogenic controlled SOA (biogenic SOA fixed at $\left.13 \mathrm{Tg}(\mathrm{SOA}) \mathrm{a}^{-1}\right)$. In panels (c) and (d) AMS observations have been weighted to remove bias in the observational dataset as described in Sect. 3.2.

$\mathrm{m}^{-3}, r^{2}=0.0$ ) or $\mathrm{OH}$ (simulation $26, \mathrm{NME}=83 \%$, $\left.\mathrm{RMSE}=4.6 \mu \mathrm{g} \mathrm{m}^{-3}, r^{2}=0.0\right)$. Including a reaction that represented acid-catalysed production of SOA from biogenic VOCs (simulations 27-28) results in a slight improvement in model skill $\left(\mathrm{NME}=80 \%, \mathrm{RMSE}=4.0 \mu \mathrm{g} \mathrm{m}^{-3}, r^{2}=0.0\right)$. Including a reaction that represents anthropogenic pollution catalysis of biogenic SOA (simulations 29-32) also results in a slight improvement in model skill (NME $=80 \%$, $\left.\mathrm{RMSE}=3.9 \mu \mathrm{g} \mathrm{m}^{-3}, r^{2}=0.01\right)$. However, the comparison between model and observations was substantially poorer than in simulations where the SOA source was linked directly to anthropogenic $\mathrm{CO}$ emissions. It is important to stress that we do not suggest that this simple empirical scheme where a source of SOA is linked to CO emissions describes the mechanism behind SOA formation, just that our method is unable to discriminate between sources which result in similar spatial patterns of SOA concentration.

Of the global model simulations we completed, the best fit with observations (simulation, $16, \mathrm{NMB}=-23 \%$, $\left.\mathrm{NME}=50 \%, \mathrm{RMSE}=2.9 \mu \mathrm{g} \mathrm{m}^{-3}, r^{2}=0.25\right)$ is with an anthropogenically controlled SOA source of $114 \mathrm{Tg}(\mathrm{SOA}) \mathrm{a}^{-1}$ and no SOA from other sources. The agreement with this simulation is even better when considering only remote sites $\left(\mathrm{NMB}=-10 \%, \mathrm{NME}=41 \%, \mathrm{RMSE}=1.3 \mu \mathrm{g} \mathrm{m}^{-3}\right.$, $\left.r^{2}=0.51\right)$ demonstrating that the anthropogenically controlled SOA source improves simulated OOA in remote as well as polluted urban locations. However, without any biogenic or biomass SOA sources, the concentrations of OOA during AMAZE are underpredicted by almost a factor 10. In the next section we use the global model simulations to optimise the SOA sources.

\subsection{Estimation of the global SOA source}

We assumed that the optimum SOA source is that which gives the smallest NME between model and observations. To estimate this SOA source we make linear interpolations between the global model simulations in Sect. 3.1. Below we demonstrate that the SOA simulated by the global model is linear with respect to SOA sources and that this approach is vaild. In Sect. 3.4 and 3.5 we test the SOA sources estimated here in the global model to confirm that they improve simulation of the AMS observations.

We created linear models that recreate the SOA simulated by the global model as a function of the 5 different SOA sources described in Sect. 2.2. We created a separate linear model for each of the 47 AMS observations in our dataset. We used as input the global model simulations 1-16 (Table 2) as these resulted in the best match with the AMS 
(a) Monoterpene

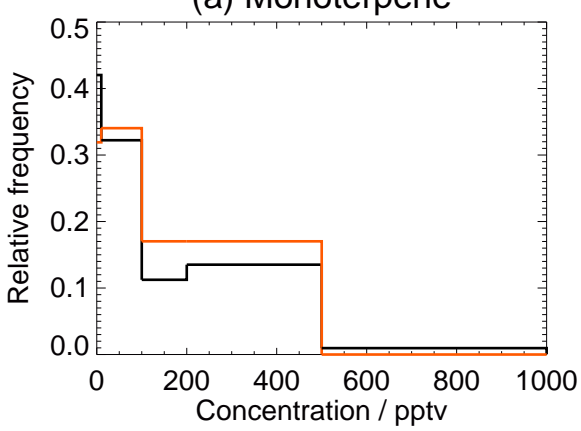

(c) $\mathrm{VOC}_{\mathrm{A}}$

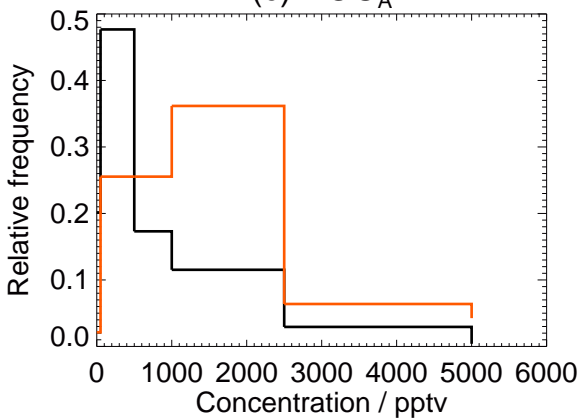

(b) Isoprene

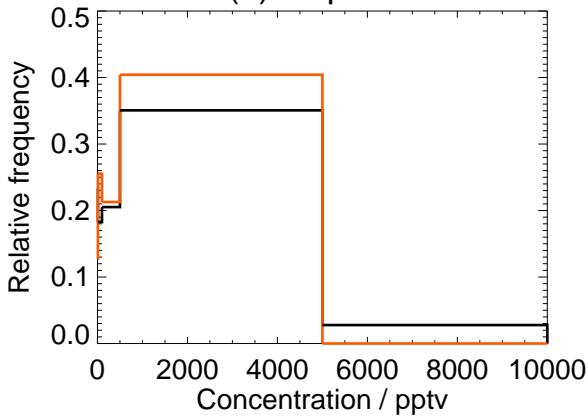

(d) $\mathrm{VOC}_{\mathrm{BB}}$

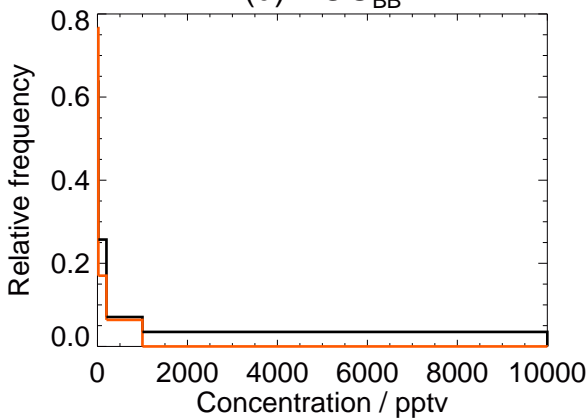

Fig. 6. Probability distribution of (a) monoterpenes, (b) isoprene, (c) anthropogenic VOC $\left(\mathrm{VOC}_{\mathrm{A}}\right)$ and (d) biomass burning VOC (VOC $\mathrm{BB}$ ) as a function of concentration. The black line shows simulated probability distribution for all global land surface (excluding Antarctica). The orange line shows simulated distribution at the locations and times of the AMS observations.

observations. We did not use simulations $17-32$, where we explored potential pathways for anthropogenic enhancement of SOA formation from BVOCs, since they did not match the AMS observations as well as a simple model of anthropogenic SOA formation. Including all the formation pathways tested here would result in too many sources to fit given the limited availability of AMS data to constrain the solution. We do not think that this analysis discounts the mechanisms tested in simulations 17-32, however the rates, yields, or functional dependences may not be well captured by our simple parameterizations. There are also likely to be additional mechanisms that are possible that we did not try. This is a large functional and parameter space, that needs to be explored further with guidance from laboratory and field experiments. The SOA calculated by each global model simulation was interpolated to the location and time period of the AMS observation as in Sect. 3.1. At each AMS location we then calculated a multiple linear fit of the interpolated SOA (SOA_int) simulated by the 16 global simulations as a function of the 5 different SOA sources: monoterpene $\left(S_{\mathrm{M}}\right)$, isoprene $\left(S_{\mathrm{I}}\right)$, anthropogenic $\left(S_{\mathrm{A}}\right)$, biomass burning $\left(S_{\mathrm{BB}}\right)$ and ageing of POA $\left(S_{\mathrm{P}}\right)$ resulting in a linear equation of the form:

SOA_int $=a \times S_{\mathrm{M}}+b \times S_{\mathrm{I}}+c \times S_{\mathrm{A}}+d \times S_{\mathrm{BB}}+e \times S_{\mathrm{P}}+f$,

where $a, b, c, d$ and $e$ are the regression coefficients and $f$ is the error term. Each linear equation was then used to calculate simulated SOA at that location. We ran each of the
47 models over same range of SOA sources simulated by the global model but at much finer increments in SOA source and over the full combination of the 5 different sources. For each combination of the SOA sources we then calculated the NME between the SOA simulated by the 47 models and the 47 AMS observations.

To evaluate the linear models we ran 6 additional global model simulations. We compared results from these simulations (which were not used to build the linear models) with output from the linear models. We found that the linear models well matched the global model $(\mathrm{NME}=0.6 \%, \mathrm{NMB}=-$ $0.17 \%, r^{2}=0.99$ ). Since the system is linear and well behaved it is appropriate to use simple linear interpolation to emulate the behaviour of the global model.

Figure $5 \mathrm{a}, \mathrm{b}$ shows NME between SOA simulated by the linear models and OOA observed by the AMS as a function of SOA source. The NME is calculated across all AMS locations. The minimum in NME between simulated and observed SOA is $47.5 \%$. We calculated the optimum SOA sources as those that resulted in the minimum NME.

Using the method described above gives an optimised SOA source of $130 \mathrm{Tg}(\mathrm{SOA}) \mathrm{a}^{-1}$, consisting of $1 \mathrm{Tg}(\mathrm{SOA}) \mathrm{a}^{-1}$ from isoprene, $1 \mathrm{Tg}(\mathrm{SOA}) \mathrm{a}^{-1}$ from monoterpenes, $2 \mathrm{Tg}(\mathrm{SOA}) \mathrm{a}^{-1}$ from biomass burning, $95 \mathrm{Tg} \mathrm{a}^{-1}$ from anthropogenically controlled SOA and $30 \mathrm{Tg} \mathrm{a}^{-1}$ from POA to OOA conversion. We also estimated the SOA sources using observations of OOA 
and total OA. This did not impact our estimated source greatly: total SOA source was $135 \mathrm{Tg}(\mathrm{SOA}) \mathrm{a}^{-1}$, consisting of $1 \mathrm{Tg}(\mathrm{SOA}) \mathrm{a}^{-1}$ from isoprene, $1 \mathrm{Tg}(\mathrm{SOA}) \mathrm{a}^{-1}$ from monoterpenes, $2 \mathrm{Tg}(\mathrm{SOA}) \mathrm{a}^{-1}$ from biomass burning, $100 \mathrm{Tg}(\mathrm{SOA}) \mathrm{a}^{-1}$ from anthropogenically controlled SOA and $30 \mathrm{Tg}(\mathrm{SOA}) \mathrm{a}^{-1}$ from POA to OOA conversion.

\subsection{Representativeness of AMS dataset}

The AMS observations used in our analysis are not equally distributed around the globe since the majority of observations were made during the summer in the $\mathrm{NH}$ mid-latitudes. This unequal distribution may introduce a bias into our estimated SOA sources. To explore this possibility we tested how representative the AMS dataset was in terms of the concentration probability distribution of the different VOCs in our SOA scheme. Because coincident AMS and VOC observations are rarely available we were not able to compare simulated versus observed VOC concentrations at the AMS locations. Instead we compared the GLOMAP simulated probability distribution of VOC concentrations over all continental locations (excluding Antarctica) against the GLOMAP simulated probability distribution of VOC concentrations but restricted to the locations and time periods of the AMS observations. Figure 6 compares these two simulated distributions.

We found that simulated VOC concentrations at the AMS locations were broadly representative of the global simulated distribution of isoprene and monoterpenes (except that the highest concentrations of both are underrepresented), but are skewed to high $\mathrm{VOC}_{\mathrm{A}}$ and low $\mathrm{VOC}_{\mathrm{BB}}$ concentrations. For example, about $35 \%$ of the AMS observations are in locations where simulated $\mathrm{VOC}_{\mathrm{A}}$ is between $200-500 \mathrm{pptv}$, whereas only about $10 \%$ of the continental grid squares have this concentration in the global model. This skew to polluted locations is because the majority of AMS observations have taken place in the relatively polluted NH mid-latitudes. This analysis can be used to suggest where future AMS observations should be prioritised. Locations with $\mathrm{VOC}_{\mathrm{A}}<20 \mathrm{pptv}$ and high isoprene, monoterpene or $\mathrm{VOC}_{\mathrm{BB}}$ in Fig. 1 (e.g. many locations in the tropical Southern Hemisphere, such as the Amazon basin, Central Africa, Northern Australia) would diversify the observation dataset most effectively.

To remove this sampling bias from the AMS dataset we weighted each AMS observation by the ratio of the frequency of occurrence in the probability distribution for that location and the frequency of occurrence in the global probability distribution. We did this cumulatively for each VOC. This particularly increased the weight of AMS observations at low $\mathrm{VOC}_{\mathrm{A}}$ concentrations and resulted in the most heavily weighted observations being central Amazon (AMAZE, weighted by a factor 12) and coastal Chile (VOCALS, weighted by a factor 7 ).

We reran our linear equations, but now using the weighting according to the above analysis. Figure $5 \mathrm{c}$ and $\mathrm{d}$ show the NME between the model and the weighted dataset. The esti- mated SOA source using these weighted observations was $140 \mathrm{Tg}(\mathrm{SOA}) \mathrm{a}^{-1}$, consisting of $7 \mathrm{Tg}(\mathrm{SOA}) \mathrm{a}^{-1}$ from isoprene, $6 \mathrm{Tg}(\mathrm{SOA}) \mathrm{a}^{-1}$ from monoterpenes, $3 \mathrm{Tg}(\mathrm{SOA}) \mathrm{a}^{-1}$ from biomass burning, $100 \mathrm{Tg}(\mathrm{SOA}) \mathrm{a}^{-1}$ anthropogenically controlled SOA and $23 \mathrm{Tg}(\mathrm{SOA}) \mathrm{a}^{-1}$ from aged POA. Weighting the observations therefore does not greatly impact the total estimated SOA source or the source from anthropogenic pollution, biomass burning or from aged POA, but increases the SOA from biogenic sources from 2 to $13 \mathrm{Tg}(\mathrm{SOA}) \mathrm{a}^{-1}$. We also estimated the SOA sources using both observations of OOA and total OA. As before this did not change the estimated SOA sources greatly: total SOA source estimated as $145 \mathrm{Tg}(\mathrm{SOA}) \mathrm{a}^{-1}$ consisting of from $6 \mathrm{Tg}(\mathrm{SOA}) \mathrm{a}^{-1}$ from isoprene, $6 \mathrm{Tg}(\mathrm{SOA}) \mathrm{a}^{-1}$ from monoterpenes, $4 \mathrm{Tg}(\mathrm{SOA}) \mathrm{a}^{-1}$ from biomass burning, $100 \mathrm{Tg}(\mathrm{SOA}) \mathrm{a}^{-1}$ anthropogenically controlled SOA and $31 \mathrm{Tg}(\mathrm{SOA}) \mathrm{a}^{-1}$ from aged POA.

Our different methods of estimating the SOA sources described in Sects. 3.2 and 3.3 (weighted or unweighted AMS dataset, using OOA or both OA and OOA observations) changes the total estimated SOA source by less than $10 \%$ (range: $130-145 \mathrm{Tg}(\mathrm{SOA}) \mathrm{a}^{-1}$ ). The anthropogenically controlled SOA source we estimate appears to be robust, with the different approaches changing the estimated source by less than $5 \%$ (range: $95-100 \mathrm{Tg}(\mathrm{SOA}) \mathrm{a}^{-1}$ ). The biomass burning source is uncertain but always relatively small in our analysis (range: $2-4 \mathrm{Tg}(\mathrm{SOA}) \mathrm{a}^{-1}$ ). Both the biogenic SOA (monoterpenes and isoprene, range: $2-13 \mathrm{Tg}(\mathrm{SOA}) \mathrm{a}^{-1}$ ) and aged POA sources $\left(23-31 \mathrm{Tg}(\mathrm{SOA}) \mathrm{a}^{-1}\right)$ are less well constrained due to the limited number of observations that have been made in air that is both heavily impacted by these sources and remote enough from anthropogenic pollution so as the signal from these smaller sources is not swamped.

For the rest of this work we refer to the the best matched SOA source as that calculated using OOA observed by the AMS using the weighted dataset. We believe that this is likely to give the strongest constraint using our method. However, as we have shown our choice of method does not greatly impact our global total estimated SOA source.

The anthropogenic controlled SOA source that we estimate here is greater than suggested in previous studies. We discuss this discrepancy further in Sect. 3.7 and 3.8. We therefore created an alternative set of SOA sources where we restricted the anthropogenic controlled SOA to $10 \mathrm{Tg}(\mathrm{SOA}) \mathrm{a}^{-1}$, roughly in line with some previous estimates (Henze et al., 2008; de Gouw and Jimenez, 2009). To match the unweighted OOA observations we then increased the biogenic SOA source from monoterpenes until we removed the model bias. We needed to increase the monoterpene SOA source to $195 \mathrm{Tg}(\mathrm{SOA}) \mathrm{a}^{-1}$ (total SOA source of $\left.238 \mathrm{Tg}(\mathrm{SOA}) \mathrm{a}^{-1}\right)$, to remove model bias. This SOA source results in substantially greater model error than our best estimate source. 
(a)

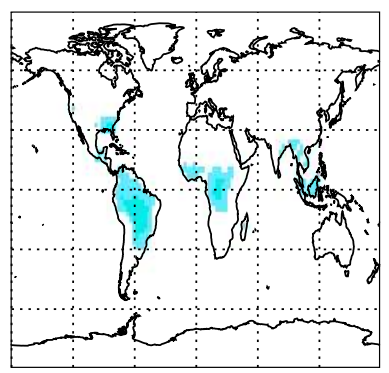

$0.02 .04 .06 .08 .010 .0 \mu \mathrm{g} \mathrm{m}^{-3}$

(d) Biogenic SOA

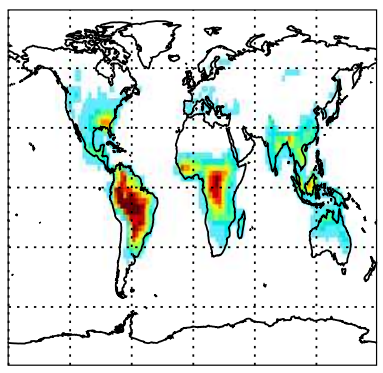

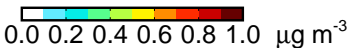

(b)

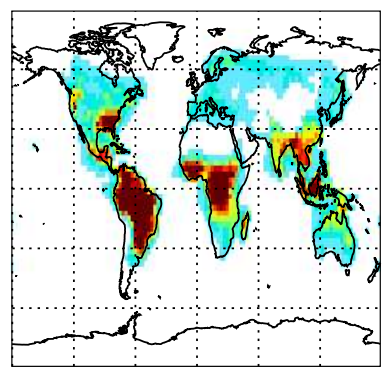

$0.02 .04 .06 .08 .010 .0 \mu \mathrm{g} \mathrm{m}^{-3}$

(e) Biomass burning SOA + POA ageing

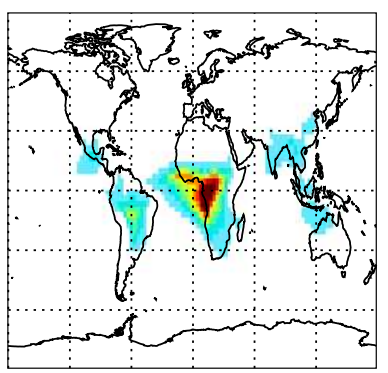

$0.00 .40 .81 .21 .62 .0 \mu \mathrm{g} \mathrm{m}^{-3}$ (c)

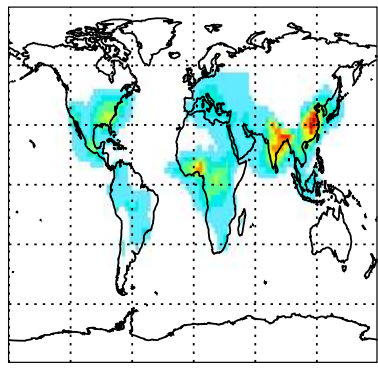

$0.02 .04 .06 .08 .010 .0 \mu \mathrm{g} \mathrm{m}^{-3}$

(f) Anthropogenic controlled SOA

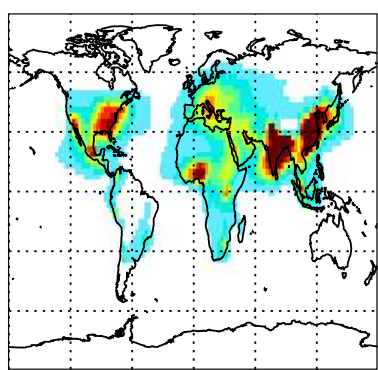

$0.00 .81 .62 .43 .24 .0 \mu \mathrm{g} \mathrm{m}^{-3}$

Fig. 7. Surface annual mean concentrations of SOA simulated in (a) standard model (simulation 1), (b) with enhanced biogenic SOA (simulation 3) and (c) with best estimate SOA sources (simulation 33). For our best estimate sources the contribution from (d) biogenic SOA only, (e) biomass SOA and POA ageing, and (e) anthropogenic pollution controlled SOA are shown. The colour scales saturate.
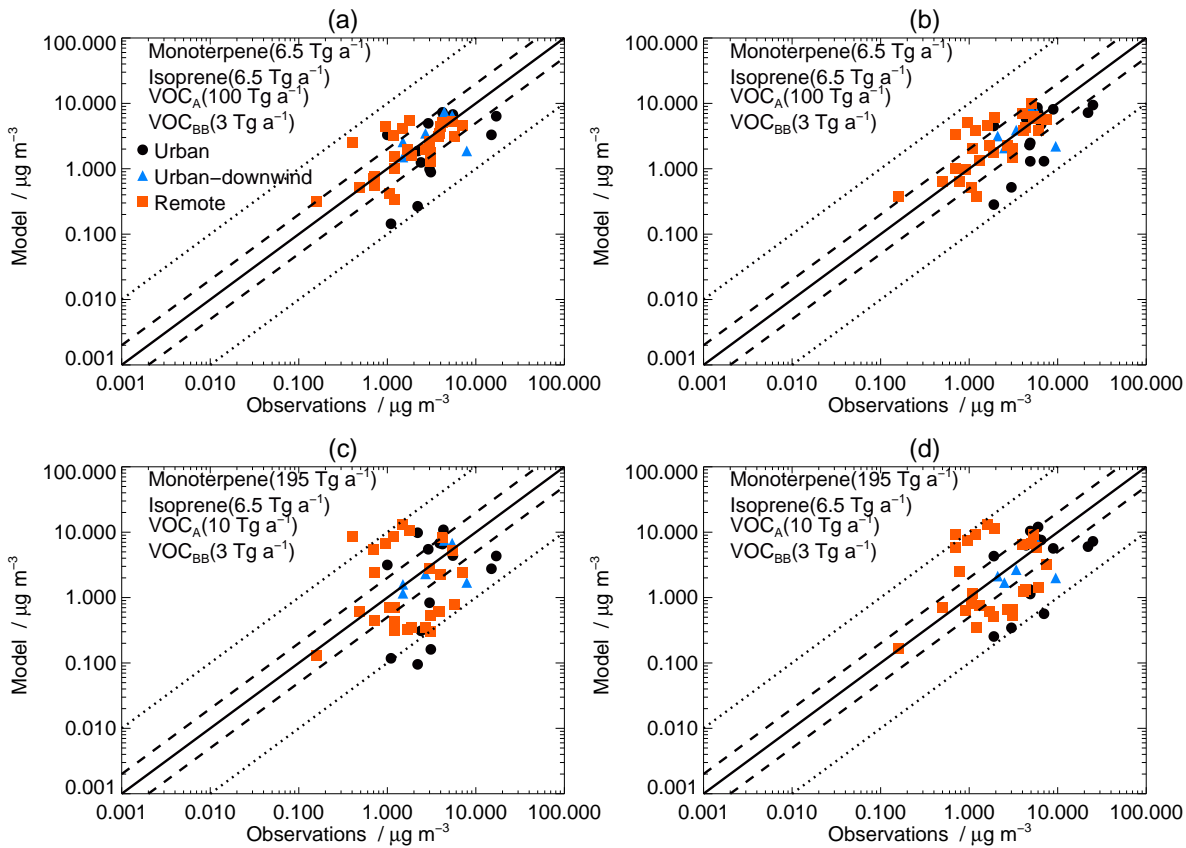

Fig. 8. As for Fig. 3 for (a) OOA and (b) OA with our best estimate SOA sources (simulation 33) and (c) OOA and (d) OA with best estimate sources but restricted anthropogenic SOA (simulation 34). 

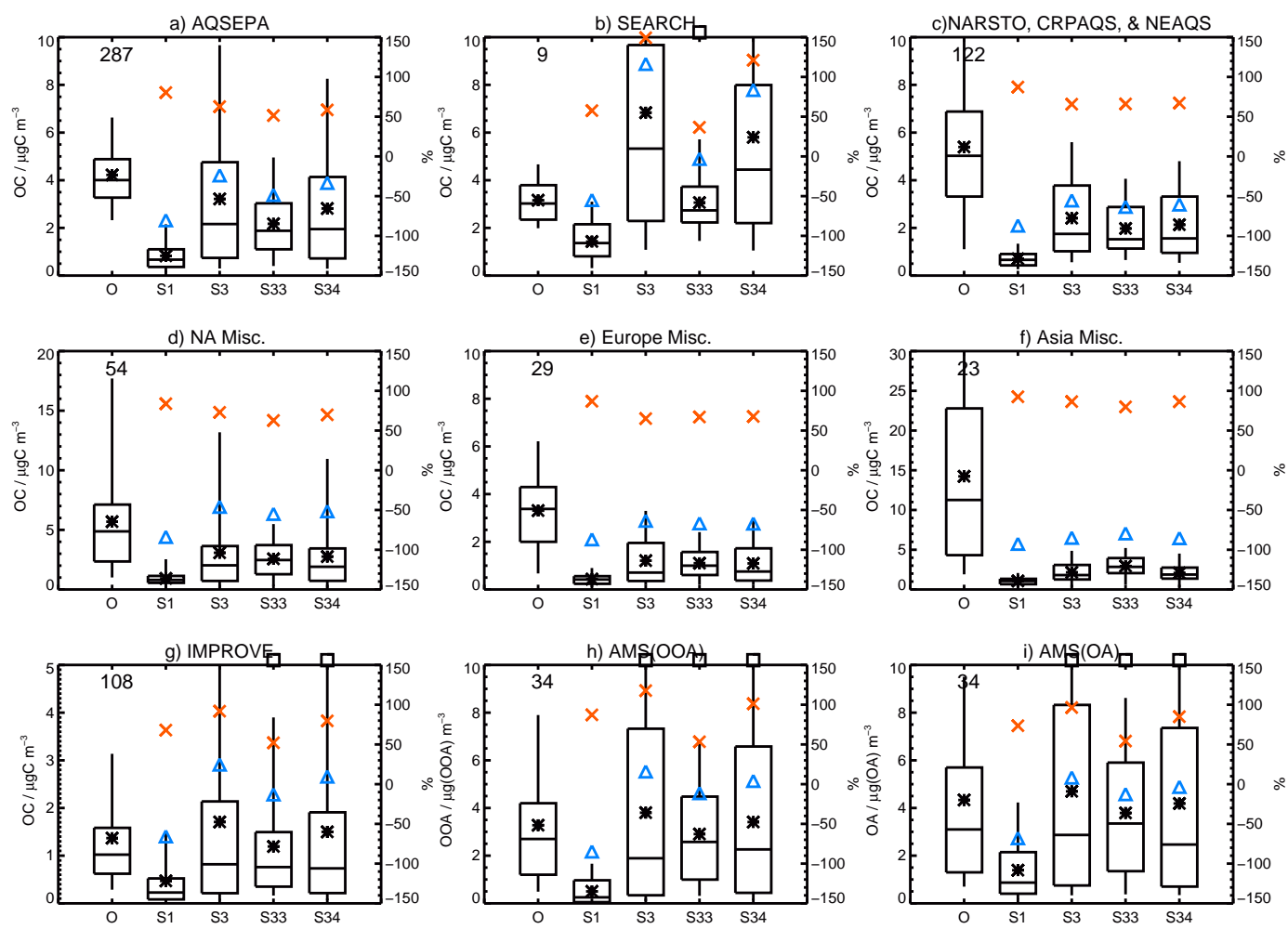

Fig. 9. Box and whisker plots showing observed $(\mathrm{O})$ and simulated (S) monthly mean organic carbon (OC) aerosol. Panels (a) through (g) are OC concentrations from Bahadur et al. (2009) (see Sect. 2.4 for details). Observations from the AMS are shown in panels (h) OOA and (i) OA. The number of separate locations is reported in each panel. Four different model simulations are shown (Table 1) S1: standard model (monoterpene SOA: $32.3 \mathrm{Tg}(\mathrm{SOA}) \mathrm{a}^{-1}$ ); S3: enhanced biogenic SOA (monoterpene SOA: 246.0 Tg (SOA) a ${ }^{-1}$ ); S33: our best estimate SOA sources (monoterpene: $6.5 \mathrm{Tg}(\mathrm{SOA}) \mathrm{a}^{-1}$, isoprene: $6.5 \mathrm{Tg}(\mathrm{SOA}) \mathrm{a}^{-1}$, biomass burning: $3 \mathrm{Tg}(\mathrm{SOA}) \mathrm{a}^{-1}, \mathrm{POA}$ to $\mathrm{SOA}$ ageing: $23 \mathrm{Tg}(\mathrm{SOA}) \mathrm{a}^{-1}$, anthropogenic controlled SOA: $\left.100 \mathrm{Tg}(\mathrm{SOA}) \mathrm{a}^{-1}\right) ; \mathrm{S} 34$ best estimate sources but with restricted anthropogenic SOA (as S33 but anthropogenic controlled SOA: $10 \mathrm{Tg}(\mathrm{SOA}) \mathrm{a}^{-1}$, monoterpene SOA: $195 \mathrm{Tg}(\mathrm{SOA}) \mathrm{a}^{-1}$ ). The average of the monthly means is shown by the star and the median of the monthly means as a horzontal line. The boxes show 25 th and 75 th percentiles, whiskers the 5th and 95th percentiles. The normalised mean bias (blue triangle) and normalised mean error (red cross) between model and observations are plotted against the right hand axis. Open squares above model simulations denote where the model is not significantly different from the observations at the $99 \%$ level $(p<0.01)$.

\subsection{Global simulations with our best estimate SOA sources}

We completed two additional GLOMAP global simulations using the SOA sources estimated above. The first simulation uses our best estimate of SOA sources and has a SOA source of $139 \mathrm{Tg}(\mathrm{SOA}) \mathrm{a}^{-1}$ with the total source dominated by anthropogenically controlled SOA (simulation 33). The second simulation has a SOA source of $238 \mathrm{Tg}(\mathrm{SOA}) \mathrm{a}^{-1}$ with the total source dominated by biogenic SOA (simulation 34). In this simulation we limited anthropogenic SOA to $10 \mathrm{Tg}(\mathrm{SOA}) \mathrm{a}^{-1}$. We compare these two simulations against the standard model (simulation $1,32 \mathrm{Tg}(\mathrm{SOA}) \mathrm{a}^{-1}$ from monoterpenes only) and the simulation with enhanced biogenic SOA (simulation 3, $246 \mathrm{Tg}(\mathrm{SOA}) \mathrm{a}^{-1}$ from monoterpenes). All the simulations are detailed in Table 2.

Figure $7(a-c)$ compares the global distribution of surface SOA concentrations simulated in the standard model (simu- lation 1), with substanially increased biogenic SOA (simulation 3) and with our best estimate SOA sources (simulation 33). In the standard model surface annual mean SOA concentrations are typically less than $2 \mu \mathrm{g} \mathrm{m}^{-3}$ with the greatest concentrations over tropical forest regions. In simulation 3, SOA concentrations are greatly increased over forested regions being greater than $10 \mu \mathrm{g} \mathrm{m}^{-3}$ over the Amazon, Congo, Borneo and SE United States. Annual mean concentrations over much of the boreal forest regions are around $2 \mu \mathrm{g} \mathrm{m}^{-3}$. With our best estimate SOA sources, annual mean surface SOA concentrations greater than $4 \mu \mathrm{g} \mathrm{m}^{-3}$ are simulated over the SE United States, India, China and the biomass burning regions of western and central Africa. Concentrations over tropical and boreal forest regions are typically less than $1 \mu \mathrm{g} \mathrm{m}^{-3}$.

Figure $7(\mathrm{~d}-\mathrm{f})$ shows the contribution of the different SOA sources to surface SOA concentrations for simulation 33. The maximum contribution from biogenic SOA is 
$1-2 \mu \mathrm{g} \mathrm{m}^{-3}$ over parts of the Amazon and Congo. Biomass burning results in SOA concentrations of $2 \mu \mathrm{g} \mathrm{m}^{-3}$ over Africa due to production from biomass burning VOCs and from POA to SOA conversion. SOA from anthropogenically controlled SOA sources exceeds $4 \mu \mathrm{g} \mathrm{m}^{-3}$ in the SE United States, India and China.

We compared the SOA in these two additional GLOMAP simulations against AMS-observed OA and OOA (Fig. 8 and Table 2). With our best estimate SOA sources (Fig. 8a and $b)$ the model better simulated both $\mathrm{OA}(\mathrm{NMB}=-12 \%$, $\left.\mathrm{NME}=59 \%, \mathrm{RMSE}=3.9 \mu \mathrm{g} \mathrm{m}^{-3}, r^{2}=0.31\right)$ and OOA $\left(\mathrm{NMB}=-11 \%, \quad \mathrm{NME}=53 \%, \quad \mathrm{RMSE}=2.9 \mu \mathrm{g} \quad \mathrm{m}^{-3}\right.$, $r^{2}=0.23$ ) compared to the standard model (simulation 1, $\mathrm{OA}: \mathrm{NMB}=-68 \%, \quad \mathrm{NME}=74 \%, \quad \mathrm{RMSE}=5.1 \mu \mathrm{g}$ $\mathrm{m}^{-3}, \quad r^{2}=0.27 ; \quad$ OOA: $\mathrm{NMB}=-85 \%, \quad \mathrm{NME}=87 \%$, $\left.\mathrm{RMSE}=4.3 \mu \mathrm{g} \mathrm{m} \mathrm{m}^{-3}, r^{2}=0.00\right)$ or the simulation with enhanced biogenic SOA formation (simulation 3, OA: $\mathrm{NMB}=8 \%, \mathrm{NME}=96 \%, \mathrm{RMSE}=5.9 \mu \mathrm{g} \mathrm{m}^{-3}, r^{2}=0.12$; OOA: $\mathrm{NMB}=16 \%, \mathrm{NME}=118 \%, \mathrm{RMSE}=5.3 \mu \mathrm{g} \mathrm{m}^{-3}$, $\left.r^{2}=0.00\right)$. We completed the same analysis against AMS sites that were classified as rural/remote. Our best estimate SOA sources better simulated $\mathrm{OA}(\mathrm{NMB}=28 \%$, $\left.\mathrm{NME}=53 \%, \quad \mathrm{RMSE}=2.0 \mu \mathrm{g} \mathrm{m}^{-3}, \quad r^{2}=0.43\right) \quad$ and OOA $\left(\mathrm{NMB}=5 \%, \mathrm{NME}=46 \%, \mathrm{RMSE}=1.5 \mu \mathrm{g} \mathrm{m} \mathrm{m}^{-3}\right.$, $\left.r^{2}=0.37\right)$ at these remote sites compared to the standard model (simulation 1, OA: $\mathrm{NMB}=-51 \%, \mathrm{NME}=67 \%$, $\mathrm{RMSE}=2.3 \mu \mathrm{g} \mathrm{m}^{-3}, r^{2}=0.12$; OOA: NMB $=-80 \%$, $\left.\mathrm{NME}=87 \%, \mathrm{RMSE}=2.7 \mu \mathrm{g} \mathrm{m}^{-3}, r^{2}=0.02\right)$ or the simulation with enhanced biogenic SOA formation (simulation 3, OA: $\mathrm{NMB}=67 \%, \mathrm{NME}=146 \%$, RMSE $=5.3 \mu \mathrm{g}$ $\mathrm{m}^{-3}, \quad r^{2}=0.05 ; \quad$ OOA: $\mathrm{NMB}=48 \%, \quad \mathrm{NME}=160 \%$, $\left.\mathrm{RMSE}=5.2 \mu \mathrm{g} \mathrm{m} \mathrm{m}^{-3}, r^{2}=0.02\right)$. This demonstrates that the SOA sources we estimate are not biased by AMS observations made in urban or sub-urban locations. Our best estimate SOA sources also result in better agreement with the AMS than when we restricted anthropogenically controlled SOA to $10 \mathrm{Tg}(\mathrm{SOA}) \mathrm{a}^{-1}$ (Fig. 8c and $\mathrm{d}$, simulation 34, $\mathrm{OA}: \mathrm{NMB}=-3 \%, \quad \mathrm{NME}=85 \%$, $\mathrm{RMSE}=5.4 \mu \mathrm{g} \mathrm{m}^{-3}, \quad r^{2}=0.14 ; \quad$ OOA: $\mathrm{NMB}=4 \%$, $\left.\mathrm{NME}=101 \%, \mathrm{RMSE}=4.7 \mu \mathrm{g} \mathrm{m}^{-3}, r^{2}=0.06\right) . \quad$ Overall these comparisons demonstrate that the SOA sources estimated in sections 3.2 and 3.3 improve the global model simulation of OA and OOA.

\subsection{Evaluation against additional OC observations}

To further evaluate the sources of SOA we tested the simulated aerosol from the global model against OC observations compiled by Bahadur et al. (2009) (Fig. 9a-g). A description of the observations compiled by this study is given in Sect. 2.4. Bahadur et al. (2009) do not classify the local conditions for each OC observation so it is not possible to evaluate the model separately against urban, sub-urban and remote locations as we did for the AMS. We compared four contrasting model simulations from Table 2: the standard model (simulation 1), the simulation with substantially increased biogenic SOA (simulation 3), the simulation with our best estimate SOA sources (simulation 33, where a large fraction of total SOA was found to be anthropogenically controlled SOA) and the simulation where we restricted anthropogenic SOA to $10 \mathrm{Tg}(\mathrm{SOA}) \mathrm{a}^{-1}$ (simulation 34$)$. We also included a comparison against OA and OOA observed by the AMS (Fig. 9h-i, discussed previously in Sect. 3.4).

A number of the datasets compiled by Bahadur et al. (2009) report OC concentrations across North America (Fig. 9a-d, g). Of these datasets the IMPROVE network has the lowest mean and median observed concentrations (being a factor 3-5 lower than the other datasets from North America) possibly reflecting the spatial distribution of the IMPROVE sites which are located away from polluted locations (Malm et al., 2004). Average OC concentrations observed across Asia (Fig. 9f) are substantially greater than those observed over Europe (Fig. 9e) and North America. Sampling in Asia may be biased to urban and sub-urban sites, which may partly explain the much greater OC concentrations observed there.

The standard model (simulation 1) underpredicts the OC observations compiled by Bahadur et al. (NMB varies from $-52 \%$ to $-92 \%$ ) confirming the low bias against AMS observations (Sect. 3.1). For each dataset we use a t-test to determine if the simulated and observed mean concentrations are significantly different. We find that the mean OC simulated by the standard model is significantly different at the 99 percent level $(p<0.01)$ to mean OC from all the datasets compiled by Bahadur et al. (2009). We also show that mean OA and mean OOA simulated by the standard model is significantly different at the 99 percent level $(p<0.01)$ to mean OA and OOA observed by the AMS.

The simulation with a substantially increased biogenic SOA source (simulation 3, $246 \mathrm{Tg}$ (SOA) $\mathrm{a}^{-1}$ from monoterpenes) typically has less of an low bias. Model bias against AMS OOA $(\mathrm{NMB}=16 \%)$ and OA $(\mathrm{NMB}=8 \%)$ is relatively small as shown previously (Sect. 3.4). Across North America the model still underpredicts OC observed by AQSEPA, NARSTO, CRPAQS, and NEAQS (NMB $=-24 \%$ to $-55 \%$ ) but has a high bias against SEARCH $(\mathrm{NMB}=116 \%)$ and IMPROVE $(\mathrm{NMB}=25 \%)$. Mean OC concentrations across Europe $(\mathrm{NMB}=-63 \%)$ and Asia $(\mathrm{NMB}=-85 \%)$ are still underpredicted in this simulation. As we showed previously in Sect. 3.4 whilst the NMB against AMS observations is reduced with this simulation, the NME is greater than in the standard model. This simulation also results in increased NME against OC observations from SEARCH (NME $=49 \%$ compared to $\mathrm{NME}=7 \%$ in the standard model) and IMPROVE (NME $=2 \%$ versus $\mathrm{NME}=68 \%$ in the standard model) networks whilst model error against the other OC datasets is reduced. Simulated mean concentrations are significantly different from the observations (at the 99 percent level, $p<0.01$ ) for all datasets except OA and OOA observed by the AMS. 
The simulation with our best estimate SOA sources (simulation 33) has lower model bias than the standard simulation for all the OC datasets from Bahadur et al. (2009). Mean OC concentrations are still underpredicted across Europe $(\mathrm{NMB}=-66 \%)$ and Asia $(\mathrm{NMB}=-79 \%)$. Across North America the model has relatively little bias against IMPROVE $(\mathrm{NMB}=-12 \%)$ and SEARCH $(\mathrm{NMB}=-3 \%)$ networks but is low biased against the other datasets (NMB vary from $-48 \%$ to $-63 \%$ ). Model error (both NME and RMSE) is consistently lower for this simulation than simulations 1 and 3 although for some datasets the reduction in model error is small (e.g., for Asia). The mean concentration of OC for this simulation is significantly different from the observations (at the 99 percent level, $p<0.01$ ) for all datasets except SEARCH, IMPROVE and for OA and OOA observed by the AMS. The simulation where we resticted anthropogenic controlled SOA to $10 \mathrm{Tg}(\mathrm{SOA}) \mathrm{a}^{-1}$ (simulation 34 ) has consistently larger model error than our best estimate SOA sources (simulation 33).

Overall, the model with our best estimate SOA sources is the most consistent against the OC observations compiled by Bahadur et al. (2009). The remaining low bias aganist these $\mathrm{OC}$ observations may indicate that $\mathrm{OC}$ concentrations in the model are too low, either through missing OC sources or that deposition of OC is too fast. Alternatively, it is possible that some of the OC datasets from Bahadur et al. (2009) are biased high by sampling near urban sources and therefore may not represent regional concentrations. Bahadur et al. (2009) analyse the observations as a function of local population density and show the paucity of OC observations that have been made in non-urban Asian and European sites. Additional analysis is required to further explore this issue potentially using higher resolution regional or global models.

\subsection{Uncertainty in estimated SOA sources}

Our estimated SOA sources are uncertain due to errors in OA and OOA observed by the AMS, OA aerosol lifetime simulated by the global model and the vertical profile of OA simulated by the global model. Here we discuss and estimate the uncertainty arising due to each of these factors. We estimated an AMS observation uncertainty of $\pm 25 \%$ (Canagaratna et al., 2007). Our method relies on the simulated aerosol lifetime in the atmosphere being accurately represented by the model. The AEROCOM multi-model OA lifetime (mean \pm standard deviation) is 6.54 days $\pm 27 \%$ (Textor et al., 2006) and is well matched by the lifetime in GLOMAP (6.1 days, Mann et al., 2010). We assumed that this standard deviation in AEROCOM multi-model lifetime is representative of the uncertainty in simulated aerosol lifetime although we acknowledge that the real uncertainty could be greater than that indicated by the model diversity. The simulated vertical profile of OA is not well constrained due to a limited number of AMS observations above the BL. We estimated that uncertainty in the vertical profile introduces a $\pm 50 \%$ uncertainty in our optimised SOA budget. The magnitude of monoterpene and isoprene emissions are uncertain (e.g., Arneth et al., 2008). However, in this work we evaluate against $\mathrm{OA}$ observations so uncertainty in the magnitude of VOC emission does not directly impact the uncertainty in our estimated SOA source. We assumed that SOA was non-volatile (see Sect. 2.1). It is difficult to assess the uncertainty this introduces into our estimate and needs to be explored in future work. To give an estimate of total unceratinty we combined the errors we have quantified above in quadrature. This gave an overall estimated error in our total SOA source of $\pm 62 \%$. Our best estimate SOA source is therefore $140 \pm 90 \mathrm{Tg}(\mathrm{SOA}) \mathrm{a}^{-1}$. When we restrict anthropogenic SOA to $10 \mathrm{Tg}$ (SOA) $\mathrm{a}^{-1}$ our total SOA source is estimated as $240 \pm 140 \mathrm{Tg}(\mathrm{SOA}) \mathrm{a}^{-1}$. Combining the uncertainty range from these two simulations gives us a range in global SOA source of $50-380 \mathrm{Tg}(\mathrm{SOA}) \mathrm{a}^{-1}$. We recognise that calculating the true level of uncertainty is difficult and that additional sources of uncertainty may be present that are not accounted for here.

\subsection{Discussion of our estimated SOA sources}

Our best estimate SOA source is $140 \pm 90 \mathrm{Tg}(\mathrm{SOA}) \mathrm{a}^{-1}$. When we restrict anthropogenically controlled SOA to $10 \mathrm{Tg}(\mathrm{SOA}) \mathrm{a}^{-1}$ our best estimate total SOA source is increased to $240 \pm 140 \mathrm{Tg}(\mathrm{SOA}) \mathrm{a}^{-1}$. These estimates are about a factor 2-3 greater than the upper end of bottomup estimates used in global model studies (e.g., 12$70 \mathrm{Tg}(\mathrm{SOA}) \mathrm{a}^{-1}$, Kanakidou et al., 2005) and at the lower end of recent top-down estimates $\left(280-1820 \mathrm{Tg}(\mathrm{SOA}) \mathrm{a}^{-1}\right.$ : Goldstein and Galbally, 2007; 50-420 Tg (SOA) $\mathrm{a}^{-1}$, Hallquist et al., 2009). Our simulated global burden of SOA using our estimated SOA sources $\left(140 \mathrm{Tg}(\mathrm{SOA}) \mathrm{a}^{-1}\right)$ is $1.84 \mathrm{Tg}$ SOA, more than a factor 2 greater than recent global model studies (e.g., 0.81 Tg SOA; Henze et al., 2008).

We also attempted to estimate the source resolved SOA budget. Our estimated SOA source from ageing of POA $\left(23 \mathrm{Tg}(\mathrm{SOA}) \mathrm{a}^{-1}\right)$ is within the range $\left(10-66 \mathrm{Tg}(\mathrm{SOA}) \mathrm{a}^{-1}\right)$ from Hallquist et al. (2009) and is greater than that directly from biomass burning which is consistent with recent field observations (Cubison et al., 2011). Our estimated biogenic SOA source $\left(13 \mathrm{Tg}(\mathrm{SOA}) \mathrm{a}^{-1}\right)$ is at the lower end of previous estimates, being 1-2 orders-of-magnitude lower than the range of estimates from Goldstein and Galbally (2007) although within the very broad range $\left(0-360 \mathrm{Tg}(\mathrm{SOA}) \mathrm{a}^{-1}\right)$ from Hallquist et al. (2009). Assuming the biogenic VOC emissions we assume are correct, our biogenic SOA source of $13 \mathrm{Tg}(\mathrm{SOA}) \mathrm{a}^{-1}$ implies an SOA yield from isoprene plus monoterpenes of $\sim 2 \%$. Restricting anthropogenic SOA to $10 \mathrm{Tg}(\mathrm{SOA}) \mathrm{a}^{-1}$ increased the biogenic SOA source to $\sim$ $200 \mathrm{Tg}(\mathrm{SOA}) \mathrm{a}^{-1}$ implying an SOA yield of $\sim 30 \%$ from biogenic VOCs (including isoprene).

Our estimated anthropogenically controlled SOA source $\left(100 \mathrm{Tg}(\mathrm{SOA}) \mathrm{a}^{-1}\right)$ is above the upper end of the range 
(a)

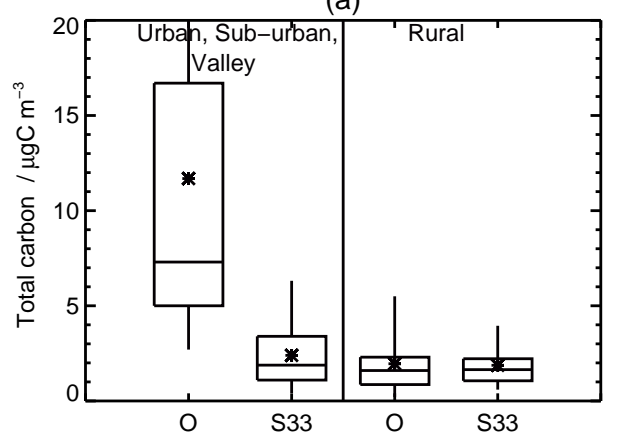

(b)

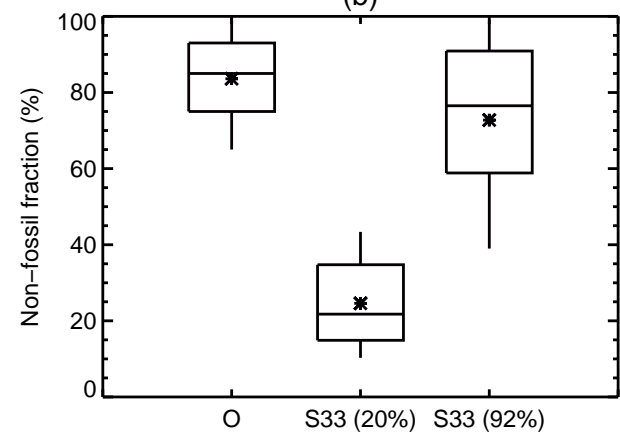

Fig. 10. Comparison of modelled (simulation 33, S33) and observed (O) (a) total carbon aerosol (left hand of panel for sites classified as urban, sub-urban and valley; right hand of panel for sites classified as rural), (b) fraction of total carbon aerosol that is non-fossil for rural sites when we assume that $20 \%$ (S33(20\%)) and $92 \%$ (S33(92\%)) of anthropogenically controlled SOA is non-fossil.

(4-24 $\left.\mathrm{Tg}(\mathrm{SOA}) \mathrm{a}^{-1}\right)$ suggested by Hallquist et al. (2009) and also above the estimate of $13.5 \mathrm{Tg}$ (SOA) $\mathrm{a}^{-1}$ from de Gouw and Jimenez (2009). This source is also substantially more than that used or predicted by previous global model studies (e.g., Tsigaridis et al., 2006; Heald et al., 2008; Henze et al., 2008, Farina et al., 2010). The origin of such a large anthropogenically controlled SOA source is unclear. It is not consistent with current understanding of SOA formation from anthropogenic VOCs as it would require an average SOA yield of $\sim 80 \%$ from anthropogenic VOCs. Whilst high SOA yields (in the order of 30-40\%) have been observed in laboratory studies under certain conditions for species such as for toluene and benzene ( $\mathrm{Ng}$ et al., 2007a; Hildebrandt et al., 2009), this yield is substantially larger than expected for the majority of anthropogenic VOCs. Recent studies predict that primary anthropogenic emissions of S/IVOCs can produce substantial quantities of SOA (Pye and Seinfeld, 2010, Jathar et al., 2011). The EDGAR inventory, from which we obtain global emissions of anthropogenic VOCs, does not include emissions of S/IVOCs and this could potentially explain some of our anthropogenically controlled SOA. To further examine the fraction of SOA that can be attributed to anthropogenic VOCs, in the next section we analyse radiocarbon data.

\subsection{Radiocarbon observations}

We used radiocarbon data to evaluate our estimated SOA sources. Measurements of the radiocarbon ${ }^{14} \mathrm{C}:{ }^{12} \mathrm{C}$ ratio in ambient aerosol have been used to estimate the fraction of total carbon aerosol that is modern (non-fossil). Such analysis shows that a large fraction (typically $80-100 \%$ ) of OC in rural regions of the SE United States is non-fossil (Bench et al., 2007; Weber et al., 2007; Ding et al., 2008).

We supplemented the ${ }^{14} \mathrm{C}$ dataset compiled by Hodzic et al. (2010b) with additional observations from Bench et al. (2007). Mass concentrations of total carbon aerosol reported in our combined ${ }^{14} \mathrm{C}$ dataset (mean $7.9 \mu \mathrm{gC} \mathrm{m}{ }^{-3}$, median $4.9 \mu \mathrm{gC} \mathrm{m} \mathrm{m}^{-3}$ ) are greater than total carbon aerosol observed by IMPROVE (year 2000 mean $1.65 \mu \mathrm{gC} \mathrm{m} \mathrm{m}^{-3}$, median $1.22 \mu \mathrm{gC} \mathrm{m}^{-3}$ ) or OA observed by AMS (mean $2.1 \mu \mathrm{gC} \mathrm{m}{ }^{-3}$, median $1.5 \mu \mathrm{gC} \mathrm{m}{ }^{-3}$ ). This may be due to the ${ }^{14} \mathrm{C}$ dataset being biased to locations and/or periods of high OC concentrations, perhaps due to the need for high amounts of $\mathrm{OA}$ for successful ${ }^{14} \mathrm{C}$ analysis, especially with older instrumentation (Schichtel et al., 2008). Both the standard (simulation 1) and model with our best estimate SOA sources model (simulation 33) underpredicted total carbon aerosol reported by this database $(\mathrm{NMB}=-85 \%$ and $\mathrm{NMB}=-72 \%$ respectively).

The location of the ${ }^{14} \mathrm{C}$ observations are classified as urban, sub-urban, valley and rural. We compare simulated and observed total carbon aerosol separately for polluted (urban, sub-urban, valley) and more remote (rural) sites (Fig. 10a). The coarse spatial resolution of the global model is unlikely to resolve urban, sub-urban or valley scale pollution and the model underpredicts total observed carbon at these locations. When restricted to remote sites, the standard model (simulation 1) underpredicted total carbon aerosol mass $(\mathrm{NMB}=-58 \%$ ) whereas the model with best estimate SOA sources (simulation 33) was in good agreement $(\mathrm{NMB}=-4 \%)$.

We therefore restricted our comparison of ${ }^{14} \mathrm{C}$ data to remote sites where the global model with our best estimate SOA sources was able to well simulate total carbon mass concentrations. The ${ }^{14} \mathrm{C}$ database has a mean non-fossil fraction of $65 \%$ across all sites and $84 \%$ when restricted to sites that are classified as remote. We note that some of the values in the dataset may overestimate non-fossil carbon by 0 $10 \%$, depending on the mix of non-fossil sources, due to not accounting for the higher ${ }^{14} \mathrm{C}$ from wood combustion (Szidat et al., 2009). However, this uncertainty is small compared to the discrepancy between observed and simulated non-fossil carbon that we report below. We calculated the non-fossil fraction simulated using our estimated SOA sources. We assumed that $20 \%$ of anthropogenically controlled SOA is 
(a)

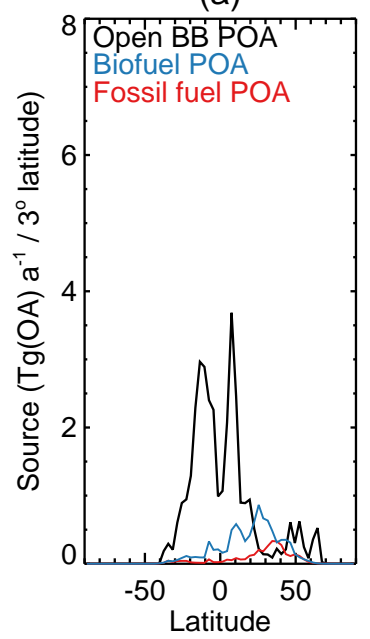

(b)

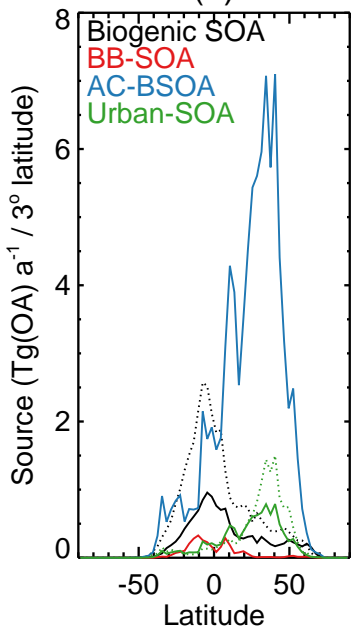

Fig. 11. Zonal mean distribution of (a) POA and (b) estimated SOA sources: biomass burning (BB-SOA); anthropogenically controlled biogenic SOA (AC-BSOA). Sources of SOA estimated in this work (solid lines) are plotted for comparison against sources estimated by de Gouw and Jimenez (2009) (dotted lines). POA emissions in the two studies are identical.

non-fossil, as our best estimate for urban pollution sources (Hildemann et al., 1994; Hodzic et al., 2010b). With this assumption we simulated an average non-fossil fraction at remote sites of $25 \%$ (NMB $=-71 \%$ ) (Fig. 10b), underpredicting non-fossil carbon $(\mathrm{NMB}=-67 \%)$ and overpredicting fossil-carbon $(\mathrm{NMB}=271 \%)$.

We then varied the fraction of our estimated anthropogenically controlled SOA source that was assumed to be nonfossil so as to match the ${ }^{14} \mathrm{C}$ data at remote sites. When we assumed that $92 \%$ of anthropogenically controlled SOA was non-fossil, the simulated mean non-fossil fraction of total carbon aerosol at remote sites was $73 \%$, close to the observed value $(\mathrm{NMB}=-13 \%)$. This suggests that at most $10 \%\left(\sim 10 \mathrm{Tg}(\mathrm{SOA}) \mathrm{a}^{-1}\right)$ of the anthropogenically controlled SOA is from fossil sources (e.g., anthropogenic VOCs or IVOCs). In the rest of the paper we define this $10 \%$ of the anthropogenically controlled SOA as Urban SOA, in line with de Gouw and Jimenez (2009). Our estimate is broadly consistent with previous estimates: $6-34 \mathrm{Tg}$ (SOA) $\mathrm{a}^{-1}$ (Hallquist et al., 2009) and $2-12 \mathrm{Tg}(\mathrm{SOA}) \mathrm{a}^{-1}$ (Henze et al., 2008) from anthropogenic VOCs and with the urban SOA source of $13.5 \mathrm{Tg}(\mathrm{SOA}) \mathrm{a}^{-1}$ estimated by de Gouw and Jimenez (2009).

The majority of our anthropogenically controlled SOA source $\left(\sim 90 \%, 90 \mathrm{Tg}(\mathrm{SOA}) \mathrm{a}^{-1}\right)$ is therefore likely to come from non-fossil sources of carbon. It is possible that a fraction of this source could arise from an underestimated impact of biomass burning in the mid latitudes, however this appears unlikely to explain a significant fraction of the source. Previous studies have suggested a role for anthropogenic pollution

in the enhancement of SOA formation from biogenic VOCs (de Gouw et al., 2005; Weber et al., 2007; Goldstein et al., 2009; Hoyle et al., 2011; Worton et al., 2011), and the recent modelling study of Carlton et al. (2010) suggests that pollution enhances biogenic SOA formation over the US by a factor of 2. Our analysis suggests that this enhancement could be even larger. Additionally, much of the effect that causes the enhancement in the Carlton et al. study (such as higher oxidants in polluted regions) are already included in our standard model. Therefore if a substantial fraction of our inferred anthropogenically controlled SOA is arising from biogenic VOC, the enhancement of SOA yield due to pollution may be greater than currently understood. If this SOA source is from biogenic VOCs then the net SOA yield from monoterpenes plus isoprene is $\sim 16 \%$.

Figure 11 shows the zonal distribution of our estimated OA sources compared to those estimated by de Gouw and Jimenez (2009). Our total OA source (both primary and secondary) is $164 \mathrm{Tg}(\mathrm{OA}) \mathrm{a}^{-1}$, with a total SOA source of $140 \mathrm{Tg}(\mathrm{SOA}) \mathrm{a}^{-1}$ (including oxidation of POA to SOA) or $117 \mathrm{Tg}(\mathrm{SOA}) \mathrm{a}^{-1}$ (excluding oxidation of POA). This compares to a total SOA source of $45 \mathrm{Tg}(\mathrm{SOA}) \mathrm{a}^{-1}$ estimated by de Gouw and Jimenez (2009). Our total SOA source is larger due to the larger anthropogenic controlled SOA source that was not included in de Gouw and Jimenez (2009). Our estimated urban SOA source is similar to that of de Gouw and Jimenez (2009). We estimate a substantial source of SOA from oxidation of POA $\left(23 \pm 15 \mathrm{Tg}(\mathrm{SOA}) \mathrm{a}^{-1}\right)$, that is not shown in Fig. 11 as it is included in the POA source.

\subsection{Estimation of aerosol forcing due to anthropogeni- cally controlled SOA}

The presence of a large anthropogenic SOA source may have an important impact on climate and radiative forcing. Substantial uncertainties in the magnitude and mechanism of this source means it is currently impossible to accurately quantify the radiative effect. Here we estimate an order of magnitude radiative effect to give an idea of the potential importance for climate. We estimate both the aerosol direct effect (ADE) and the cloud albedo (first) aerosol indirect effect (AIE) through comparing model simulations with and without out estiamted anthropogenically controlled SOA source. We estimate an uncertainty in the radiative effect of the anthropogenically controlled SOA source using the error estimates discussed in Sect. 3.7 which gives an upper $\left(160 \mathrm{Tg}(\mathrm{SOA}) \mathrm{a}^{-1}\right)$ and lower $\left(40 \mathrm{Tg}(\mathrm{SOA}) \mathrm{a}^{-1}\right)$ limit of our source estimate.

To estimate the ADE we used the anthropogenically controlled SOA burden simulated by GLOMAP along with the AeroCom multi-model mean OA burden $(0.66 \mathrm{Tg})$ and multimodel mean ADE $\left(-0.13 \mathrm{Wm}^{-2}\right)$. The GLOMAP simulated burden of anthropogenically controlled SOA $(1.3 \pm 0.8 \mathrm{Tg})$ results in an estimated ADE of $-0.26 \pm 0.15 \mathrm{Wm}^{-2}$. This estimation assumes that the optical properties and spatial 


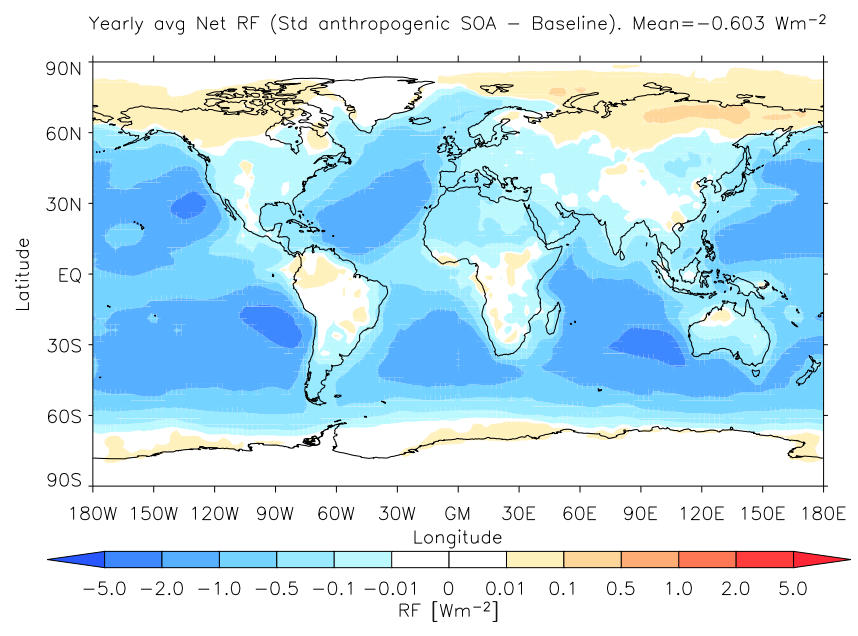

Fig. 12. Annual mean net (long wave and short wave) top of atmosphere cloud albedo radiative forcing (RF) due to anthropogenic pollution controlled SOA for a cloud updraft velocity of $0.4 \mathrm{~m} \mathrm{~s}^{-1}$.

distribution of the anthropogenic SOA are identical to that of OA within the AeroCom models. More sophisticated estimates of the ADE from anthropogenically-controlled SOA are now required.

To calculate the AIE we first calculated the cloud drop number concentrations (CDNC) with (perturbed) and without (baseline) anthropogenically controlled SOA. Both the baseline and perturbed runs included all other aerosol sources treated in this study. We calculated CDNC using the simulated aerosol size distribution and a mechanistic parameterization of cloud drop formation (Nenes and Seinfeld, 2003). We have shown previously that this method produces realistic CDNC (Merikanto et al., 2010). We calculated cloud albedo using the off-line version of the Edwards and Slingo (1996) radiative transfer model together with monthly mean climatological cloud fields and surface albedo (averaged over the period 1983-2005) from the International Satellite Cloud Climatology (ISCCP) (Rossow and Schiffer, 1999). The model uses 9 bands in the longwave and 6 bands in the shortwave and a delta-Eddington 2 stream scattering solver at all wavelengths. In our climatology, the clouds were added to three unique vertical levels, corresponding to low and middle and high clouds. Water vapour, temperature and ozone data are based on European Centre for Medium-Range Weather Forecasting reanalysis data (see Rap et al., 2010 for details). For the unperturbed and perturbed runs, cloud effective drop radius $r_{\mathrm{e}}$ (in $\mu \mathrm{m}$ ) for low and mid level water clouds was calculated from the GLOMAP CDNC (in $\mathrm{cm}^{-3}$ ) and ISCCP derived liquid water paths (LWP, in $\mathrm{g} \mathrm{m}^{-2}$ ), using the Bower et al. (1994) parameterisation, namely:

$r_{\mathrm{e}}=100 \times[\mathrm{LWP} /(\Delta z) \times 3 /(4 \pi \times \mathrm{CDNC})]^{1 / 3}$,

where $\Delta z$ is the cloud thickness, which in our climatology is roughly $1400 \mathrm{~m}$ and $2900 \mathrm{~m}$ for low and middle clouds, respectively. Only water clouds were modified.

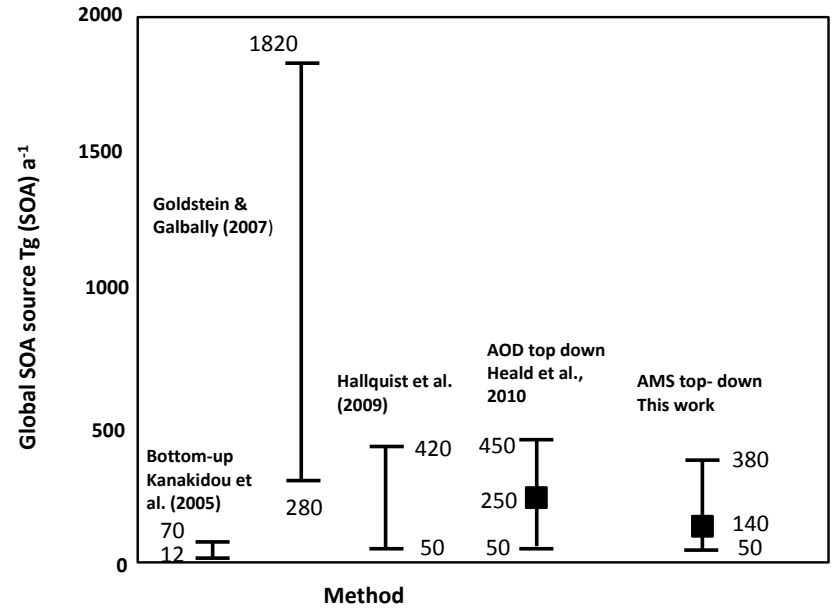

Fig. 13. Comparison of the global budget of SOA calculated here with previous work (we convert the OA source from Heald et al. (2010) into an SOA source assuming a 2:1 OA:OC conversion and the POA emissions used in this study).

The cloud albedo AIE at the top of the atmosphere was then calculated by comparing the cloud albedo calculated with anthropogenically controlled SOA compared to the cloud albedo calculated without anthropogenically controlled SOA.

Figure 12 shows the AIE due to our anthropogenically controlled SOA source. We calculate a global annual mean AIE of $-0.6_{-0.14}^{+0.24} \mathrm{Wm}^{-2}$. Our calculated AIE is substantial compared with the IPCC value of $-0.7 \pm 0.4 \mathrm{Wm}^{-2}$, which does not include SOA.

There is considerable uncertainty in our estimate of the potential radiative effect due to anthropogenically controlled SOA, due to uncertainty in the mass budget and the optical and cloud nucleating properties of the aerosol. There is also considerable uncertainty due to the volatility distribution of the SOA which controls where in the aerosol size distribution the material will condense (Riipinen et al., 2011). We have assumed essentially non-volatile SOA which likely provides an upper limit for the contribution of the material to $\mathrm{CCN}$ concentrations and leads to a substantial and negative AIE. If the material was partially semi-volatile, condensation on larger particles would be enhanced resulting in reduction in nanoparticle growth rates and an enhancement of the condensational sink which would suppress nucleation. This would suppress and potentially reverse the enhancement to CCN and CDNC and hence lead to a smaller negative or even positive AIE. This can be seen in the study of Arneth et al. (2010) who calculated that SOA (largely from biogenic sources) contributes a global mean all-sky ADE of $-0.08 \mathrm{Wm}^{-2}$ but a positive AIE of $0.3 \mathrm{Wm}^{-2}$. Future work is needed to explore uncertainties in the volatility and contribution of SOA to particle growth rates and the interaction with BL particle formation (Spracklen et al., 2008a) both of 
which may greatly impact the contribution to the formation of $\mathrm{CCN}$ and the AIE.

\section{Conclusions}

We have used a global dataset of organic aerosol (OA) and oxygenated organic aerosol (OOA) observed by the aerosol mass spectrometer (AMS) to evaluate the GLOMAP global aerosol model. The dataset includes observations from 47 field campaigns at 34 different locations. The standard GLOMAP model (Mann et al., 2010) which has SOA from monoterpenes only $\left(32 \mathrm{Tg}(\mathrm{SOA}) \mathrm{a}^{-1}\right)$, underpredicts $\mathrm{OA}$ (normalised mean bias $(\mathrm{NMB})=-68 \%$ ) and OOA $(\mathrm{NMB}=-85 \%)$ observed by the AMS and has little skill simulating the variability in the dataset $(\mathrm{OA}$, normalised mean error $(\mathrm{NME})=74 \%$, root mean square error $(\mathrm{RMSE})=5.1 \mu \mathrm{g} \mathrm{m}^{-3} ;$ OOA, NME $=87 \%$, $\left.\operatorname{RMSE}=4.3 \mu \mathrm{g} \mathrm{m}^{-3}\right)$. When we restricted the analysis to remote (excluding urban and suburban) sites model underprediction $(\mathrm{OA}, \mathrm{NMB}=-51 \%$; $\mathrm{OOA}, \mathrm{NMB}=-80 \%)$ and lack of model skill $\left(\mathrm{OA}, \mathrm{NME}=67 \%\right.$, RMSE $=2.3 \mu \mathrm{g} \mathrm{m}^{-3}$; $\mathrm{OOA}, \mathrm{NME}=87 \%, \mathrm{RMSE}=2.7 \mu \mathrm{g} \mathrm{m}^{-3}$ ) remained, demonstrating that model bias is not driven by underprediction of urban scale aerosol plumes.

We ran multiple GLOMAP simulations varying the secondary organic aerosol (SOA) source from 5 different sources: monoterpenes, isoprene, lumped anthropogenic and lumped biomass burning volatle organic compounds (VOCs) and from ageing of primary OA to SOA. Our aim was to estimate the global SOA source that would result in the best match with the AMS dataset. We did not attempt a formal model inversion. Instead we made linear interpolations between the OA and OOA from our global model simulations and used these to estimate the SOA sources that resulted in a minimum in NME against OA and OOA observed by the AMS. We then used the SOA sources estimated by this analysis within the 3D global model and re-evaluated the model against the AMS dataset. Using this method our best estimate of the global SOA source was $140 \mathrm{Tg}(\mathrm{SOA}) \mathrm{a}^{-1}$, but with a large uncertainty range which we estimate to be $50-380 \mathrm{Tg}(\mathrm{SOA}) \mathrm{a}^{-1}$. Applying the best estimate SOA source in the global model improved the simulation of OA and OOA both when calculated across all AMS sites $(\mathrm{OA}, \mathrm{NMB}=-12 \%, \mathrm{NME}=54 \%$, $\mathrm{RMSE}=3.9 \mu \mathrm{gvm}^{-3} ; \mathrm{OOA}, \mathrm{NMB}=-11 \%, \mathrm{NME}=53 \%$, RMSE $\left.=2.9 \mu \mathrm{g} \mathrm{m}^{-3}\right)$ and when resticted to remote sites (OA, $\mathrm{NMB}=28 \%, \mathrm{NME}=53 \%, \mathrm{RMSE}=2.0 \mu \mathrm{g} \mathrm{m}^{-3} ; \mathrm{OOA}$, $\left.\mathrm{NMB}=5 \%, \mathrm{NME}=46 \%, \mathrm{RMSE}=1.5 \mu \mathrm{g} \mathrm{m}^{-3}\right)$.

We used organic carbon (OC) observations from across North America, Europe and Asia compiled by Bahadur et al. (2009) to further evaluate SOA sources in our model. The standard model is biased low against all the different datasets from this compilation confirming the low model bias aganist the AMS. Our best estimate SOA source reduced the low model bias and was the most consistent simulation (lowest NME and RMSE) compared with this dataset. All the model simulations are biased low against the Bahadur et al. (2009) observations from Europe and Asia, although it is not clear to what extent this is driven by OC observations in these continents being made largely in urban and sub-urban regions.

Our estimated SOA source is a factor of 2-3 greater than bottom-up estimates but at the lower end of some previous top-down studies (Fig. 13). Our best estimate of the global OA source (including primary organic aerosol) is $164 \mathrm{Tg}(\mathrm{OA}) \mathrm{a}^{-1}$. This estimate is within the uncertainty range of a recent top-down estimate of the OA budget using satellite observations of aerosol optical depth and a global model (Heald et al., 2010) which suggested an OA source of $300 \pm 240 \mathrm{Tg}(\mathrm{OA}) \mathrm{a}^{-1}$ (assuming a 2:1 OA:organic carbon (OC) conversion).

We found that increasing the source of biogenic SOA reduced the bias between the model and the AMS dataset but did not reduce the model error (as quantified by NME and RMSE). The best match (smallest NME) occured when we assumed a large source $\left(100 \mathrm{Tg}(\mathrm{SOA}) \mathrm{a}^{-1}\right)$ of SOA from a VOC precursor with emissions that spatially matched anthropogenic $\mathrm{CO}$ emissions. We refer to this SOA as anthropogenically controlled to underline that it may come from a variety of different sources that would have emission patterns similar to anthropogenic CO emissions. Such sources, which have been previously suggested in the literature, include (a) SOA formed directly from oxidation of anthropogenic VOCs (e.g., Henze et al., 2008), (b) semivolatile and intermediate volatility organic compounds (S/IVOCs, Robinson et al., 2007), (c) enhancement of biogenic SOA production due to anthropogenic pollution (e.g., de Gouw et al., 2005; Weber et al., 2007), (d) meat cooking, or (e) wood smoke emissions. The model with a large anthropogenically controlled SOA source was also the most consistent of our simulations when compared against the Bahadur et al. (2009) dataset, although in many cases model improvement (compared to a large biogenic SOA source) was slight.

Our best estimate of the other SOA sources are $13 \mathrm{Tg}(\mathrm{SOA}) \mathrm{a}^{-1}$ from biogenic sources (isoprene and monoterpenes), $3 \mathrm{Tg}(\mathrm{SOA}) \mathrm{a}^{-1}$ from biomass burning and $23 \mathrm{Tg}$ (SOA) $\mathrm{a}^{-1}$ from conversion of POA (which are mostly from biomass burning sources). Our estimated anthropogenically controlled SOA source results in a larger SOA source in the Northern Hemisphere mid-latitudes than in previous studies. In our model SOA accounts for $85 \%$ of total OA sources when we include ageing of primary to secondary OA and $71 \%$ when we do not.

We used ${ }^{14} \mathrm{C}$ (radiocarbon) observations to help characterise a potential anthropogenic controlled SOA source. We restrict our analysis to radiocarbon observations made at remote sites where the global model is able to capture the observed total carbon concentrations. However, we note that the majority of radiocarbon observations have been made in urban or sub-urban locations and we suggest that additional 
radiocarbon observations are required at remote sites. Assuming that the origin of carbon is from fossil sources, as would be the case for a substantial contribution to SOA from anthropogenic VOCs or S/IVOCs, is inconsistent with measured fractions of non-fossil carbon in $\mathrm{OA}$ in remote regions. To match the non-fossil fraction calculated from ${ }^{14} \mathrm{C}$ observations we estimate that a maximum of $\sim 10 \mathrm{Tg}(\mathrm{SOA}) \mathrm{a}^{-1}$ can be formed directly from fossil sources. The majority of an anthropogenically controlled SOA source must therefore come from a carbon source with a non-fossil origin. Such sources include anthropogenic pollution enhancement of biogenic SOA, meat cooking and biomass burning.

A number of previous studies have suggested that SOA formation from biogenic VOCs may be enhanced by anthropogenic pollution (e.g., de Gouw et al., 2005; Weber et al., 2007; Goldstein et al., 2009; Hoyle et al.,, 2011; Worton et al., 2011). Carlton et al. (2010) use the terms "controllable" and "non-controllable" to classify SOA from biogenic VOCs, and suggests that about $1 / 2$ of the SOA from biogenic VOCs is controllable. Our work suggests that the controllable fraction of SOA may be even larger, but says nothing about the mechanism and therefore gives little guidance to policy efforts that might be aimed at reducing SOA. Future process studies in the field and the laboratory are needed to further explore anthropogenic SOA formation processes.

We calculate an order of magnitude estimate of the radiative effect due to our estimated anthropogenic SOA source. Substantial uncertainties exist in our estimate due to uncertainty in the anthropogenic SOA budget, the optical and cloud nucleating properties of the anthropogenic SOA and the volatility distribution of the SOA which controls where in the aerosol size distribution the material will condense (Riipinen et al., 2011). We estimate that an anthropogenically controlled SOA source of the magnitude suggested here results in an aerosol direct effect of $-0.26 \pm 0.15 \mathrm{Wm}^{-2}$ and a cloud albedo aerosol indirect effect of $-0.6_{-0.14}^{+0.24} \mathrm{Wm}^{-2}$. Our calculated cloud albedo radiative effect is substantial compared to the aerosol indirect effect from all anthropogenic aerosol of $-0.7 \pm 0.4 \mathrm{Wm}^{-2}$ calculated by the IPCC (Forster et al., 2007), but which did not include SOA. Future studies using different models are now needed to confirm these estimates.

In this study we assumed SOA had negligible vapour pressure and condenses irreversibly onto pre-exisiting aerosol. This is consistent with recent observations that suggest that aged SOA has low volatility (e.g., Jimenez et al., 2009; Cappa and Jimenez, 2010; Vaden et al., 2011; Riipinen et al., 2011). However, future studies need to explore the sensitivity of the calculated SOA budget due to uncertainties in volatility.

The AMS database used in this analysis is spatially limited, lacks information on the seasonal cycle at most locations and has very limited information on the vertical OA profile. We have shown that the location of observations in the database is representative of biogenic VOC concentrations over land, but it is biased to regions of higher anthro- pogenic pollution. We attempt to account for this bias in sampling by differentially weighting the AMS observations and find that it does not greatly alter our global total SOA source. However, this does limit our ability to estimate the magnitude of different SOA sources and we stress that in particular, the biogenic and biomass burning sources are less well constrained because of limited observations in air masses that are strongly impacted by these sources. To enable tighter constraints from analysis with the methods presented here, requires bringing together additional $\mathrm{OA}$ and $\mathrm{OC}$ observations particularly from regions that have small influence from anthropogenic pollution and large influence from biogenic and/or biomass burning sources, such as in the tropics, particularly Amazonia, Central Africa, Northern Australia, the Southern Hemisphere and remote boreal forest locations.

Acknowledgements. We acknowledge the support of the following grants: UK Natural Environmental Research Council (NERC) grant (NE/G015015/1 and NE/G006172/1 (AEROS)), US DOE (BER, ASR Program) DEFG0208ER64627, DE-SC0006035, DE-SC0006711, DE-FG02-11ER65293, US NSF ATM-0919189, and US EPA R833747.

Edited by: M. Kanakidou

\section{References}

Aiken, A. C., DeCarlo, P. F., Kroll, J. H., Worsnop, D. R., Huffman, J. A., Docherty, K. S., Ulbrich, I. M., Mohr, C., Kimmel, J. R., Sueper, D., Sun, Y., Zhang, Q., Trimborn, A., Northway, M., Ziemann, P. J., Canagaratna, M. R., Onasch, T. B., Alfarra, M. R., Prevot, A. S. H., Dommen, J., Duplissy, J., Metzger, A., Baltensperger, U., and Jimenez, J. L.: O/C and OM/OC ratios of primary, secondary and ambient organic aerosols with high-resolution time-of-flight aerosol mass spectrometry, Environ. Sci. Technol., 42(12), 4478-4485, doi:10.1021/es703009q, 2008.

Aiken, A. C., Salcedo, D., Cubison, M. J., Huffman, J. A., DeCarlo, P. F., Ulbrich, I. M., Docherty, K. S., Sueper, D., Kimmel, J. R., Worsnop, D. R., Trimborn, A., Northway, M., Stone, E. A., Schauer, J. J., Volkamer, R. M., Fortner, E., de Foy, B., Wang, J., Laskin, A., Shutthanandan, V., Zheng, J., Zhang, R., Gaffney, J., Marley, N. A., Paredes-Miranda, G., Arnott, W. P., Molina, L. T., Sosa, G., and Jimenez, J. L.: Mexico City aerosol analysis during MILAGRO using high resolution aerosol mass spectrometry at the urban supersite (T0) - Part 1: Fine particle composition and organic source apportionment, Atmos. Chem. Phys., 9, 66336653, doi:10.5194/acp-9-6633-2009, 2009.

Allan, J. D., Bower, K. N., Coe, H., Boudries, H., Jayne, J. T., Canagaratna, M. R., Millet, D. B., Goldstein, A. H., Quinn, P. K., Weber, R. J., and Worsnop, D. R.: Submicron aerosol composition at Trinidad Head, California, during ITCT 2K2: Its relationship with gas phase volatile organic carbon and assessment of instrument performance, J. Geophys. Res., 109(D23), D23S24, doi:10.1029/2003JD004208, 2004.

Arneth, A., Harrison, S. P., Zaehle, S., Tsigaridis, K., Menon, S., Bartlein, P. J., Feichter, J., Korhola, A., Kulmala, M., O’Donnell, 
D., Schurgers, G., Sorvari, S., and Vesala, T.: Terrestrial biogeochemical feedbacks in the climate system, Nat. Geosci., 3, 525532, 2010.

Arneth, A., Monson, R. K., Schurgers, G., Niinemets, Ü., and Palmer, P. I.: Why are estimates of global terrestrial isoprene emissions so similar (and why is this not so for monoterpenes)?, Atmos. Chem. Phys., 8, 4605-4620, doi:10.5194/acp-8-46052008, 2008.

Arnold, S. R., Chipperfield, M. P., and Blitz, M. A.: A threedimensional model study of the effect of new temperaturedependent quantum yields for acetone photolysis, J. Geophys. Res., 110, D22305, doi:10.1029/2005JD005998, 2005.

Arnold, S. R., Spracklen, D. V., Williams, J., Yassaa, N., Sciare, J., Bonsang, B., Gros, V., Peeken, I., Lewis, A. C., Alvain, S., and Moulin, C.: Evaluation of the global oceanic isoprene source and its impacts on marine organic carbon aerosol, Atmos. Chem. Phys., 9, 1253-1262, doi:10.5194/acp-9-1253-2009, 2009.

Bahadur, R., Habib, G., Russell, L. M.: Climatology of PM2.5 organic carbon concentrations from a review of ground-based atmospheric measurements by evolved gas analysis, Atmos. Environ., 43(9), 1591-1602, 2009.

Bench, G., Fallon, S., Schichtel, B., Malm, W., and McDade, C.: Relative contributions of fossil and contemporary carbon sources to PM 2.5 aerosols at nine Interagency Monitoring for Protection of Visual Environments (IMPROVE) network sites, J. Geophys. Res., 112, D10205, doi:10.1029/2006JD007708, 2007.

Bond, T. C., Streets, D. G., Yarber, K. F., Nelson, S. M., Woo, J.H., and Klimont, Z.: A technology-based global inventory of black and organic carbon emissions from combustion, J. Geophys. Res., 109, D14203, doi:10.1029/2003JD003697, 2004.

Canagaratna, M. R., Jayne, J. T., Jimenez, J. L., Allan, J. D., Alfarra, M. R., Zhang, Q., Onasch, T. B., Drewnick, F., Coe, H., Middlebrook, A., Delia, A., Williams, L. R., Trimborn, A. M., Northway, M. J., DeCarlo, P. F., Kolb, C. E., Davidovits, P., and Worsnop, D. R.: Chemical and microphysical characterization of ambient aerosols with the aerodyne mass spectrometer, Mass Spectrom. Rev., 26(2), 185-222, 2007.

Capes, G., Johnson, B., McFiggans, G., Williams, P. I., Haywood, J., and Coe, H.: Aging of biomass burning aerosols West Africa: Aircraft measurements of chemical composition, microphysical properties, and emission ratios, J. Geophys. Res., 113, D00C15, doi:10.1029/2008JD009845, 2008.

Capes, G., Murphy, J. G., Reeves, C. E., McQuaid, J. B., Hamilton, J. F., Hopkins, J. R., Crosier, J., Williams, P. I., and Coe, H.: Secondary organic aerosol from biogenic VOCs over West Africa during AMMA, Atmos. Chem. Phys., 9, 3841-3850, doi:10.5194/acp-9-3841-2009, 2009.

Cappa, C. D. and Jimenez, J. L.: Quantitative estimates of the volatility of ambient organic aerosol, Atmos. Chem. Phys., 10, 5409-5424, doi:10.5194/acp-10-5409-2010, 2010.

Cappa, C. D. and Wilson, K. R.: Evolution of organic aerosol mass spectra upon heating: implications for OA phase and partitioning behavior, Atmos. Chem. Phys. Discuss., 10, 28431-28469, doi:10.5194/acpd-10-28431-2010, 2010. .

Carlton, A. G., Pinder, R. W., Bhave, P. V., and Pouliot, G. A.: To what extent can biogenic SOA be controlled, Environ. Sci. Technol., 44, 3376-3380, doi:10.1021/es903506b, 2010.

Chan, A. W. H., Chan, M. N., Surratt, J. D., Chhabra, P. S., Loza, C. L., Crounse, J. D., Yee, L. D., Flagan, R. C., Wennberg, P. O., and Seinfeld, J. H.: Role of aldehyde chemistry and $\mathrm{NO}_{\mathrm{x}}$ concentrations in secondary organic aerosol formation, Atmos. Chem. Phys., 10, 7169-7188, doi:10.5194/acp-10-7169-2010, 2010.

Chen, Q., Farmer, D. K., Schneider, J., Zorn, S. R., Heald, C. L., Karl, T. G., Guenther, A., Allan, J. D., Robinson, N., Coe, H., Kimmel, J. R., Pauliquevis, T., Borrmann, S., Pöschl, U., Andreae, M. O., Artaxo, P., Jimenez, J. L., and Martin, S. T.: Mass spectral characterization of submicron biogenic organic particles in the Amazon Basin, Geophys. Res. Lett., 36, L20806, doi:10.1029/2009GL039880, 2009.

Chipperfield, M. P.: New version of the TOMCAT/SLIMCAT offline chemical transport model: Intercomparison of stratospheric tracer experiments, Q. J. Roy. Meteorol. Soc., 132(617B), 1179_ 1203, 2006.

Chow, J. C., Chen, L. W. A., Watson, J. G., Lowenthal, D. H., Magliano, K. A., Turkiewicz, K., Lehrman, D. E.: PM2.5 chemical composition and spatiotemporal variability during the California regional PM10/PM2.5 air quality study (CRPAQS), J. Geophys. Res.-Atmos., 111, D10S04, doi:10.1029/2005JD006457, 2006.

Cottrell, L. D., Griffin, R. J., Jimenez, J. L., Zhang, Q., Ulbrich, I., Ziemba, L. D., Beckman, P. J., Sive, B. C., and Talbot, R. W.: Submicron particles at Thompson Farm during ICARTT measured using aerosol mass spectrometry, J. Geophys. Res., 113, D08212, doi:10.1029/2007JD009192, 2008.

Cubison, M. J., Ortega, A. M., Hayes, P. L., Farmer, D. K., Day, D., Lechner, M. J., Brune, W. H., Apel, E., Diskin, G. S., Fisher, J. A., Fuelberg, H. E., Hecobian, A., Knapp, D. J., Mikoviny, T., Riemer, D., Sachse, G. W., Sessions, W., Weber, R. J., Weinheimer, A. J., Wisthaler, A., and Jimenez, J. L.: Effects of aging on organic aerosol from open biomass burning smoke in aircraft and lab studies, Atmos. Chem. Phys. Discuss., 11, 12103-12140, doi:10.5194/acpd-11-12103-2011, 2011.

DeCarlo, P. F., Ulbrich, I. M., Crounse, J., de Foy, B., Dunlea, E. J., Aiken, A. C., Knapp, D., Weinheimer, A. J., Campos, T., Wennberg, P. O., and Jimenez, J. L.: Investigation of the sources and processing of organic aerosol over the Central Mexican Plateau from aircraft measurements during MILAGRO, Atmos. Chem. Phys., 10, 5257-5280, doi:10.5194/acp-10-52572010, 2010.

de Gouw., J. A., Middlebrook., A. M., Warneke, C., Goldan, P. D., Kuster, W. C., Roberts, J. M., Fehsenfeld, F. C., Worsnop, D. R., Canagaratna, M. R., Pszenny, A. A. P., Keene, W. C., Marchewka, M., Bertman, S. B., and Bates, T. S.: Budget of organic carbon in a polluted atmosphere: Results from the New England Air Quality Study in 2002, J. Geophys. Res., 110, D16305, doi:10.1029/2004JD005623, 2005.

de Gouw, J. A., Brock, C. A., Atlas, E. L., Bates, T. S., Fehsenfeld, F. C., Goldan, P. D., Holloway, J. S., Kuster, W. C., Lerner, B. M., Matthew, B. M., Middlebrook, A., M., Onasch, T. B., Peltier, R. E., Quinn, P. K., Senff, C. J., Stohl, A., Sullivan, A. P., Trainer, M., Warneke, C., Weber, R. J., and Williams, E. J.: Sources of particulate matter in the northeastern United States in summer: 1. Direct emissions and secondary formation of organic matter in urban plumes, J. Geophys. Res., 113, D08301, doi:10.1029/2007JD009243, 2008.

de Gouw, J. and Jimenez, J. L. Organic Aerosols in the Earth's Atmosphere, Environ. Sci. Technol., 43, 7614-7618, doi:10.1021/es9006004, 2009. 
Dentener, F., Stevenson, D., Cofala, J., Mechler, R., Amann, M., Bergamaschi, P., Raes, F., and Derwent, R.: The impact of air pollutant and methane emission controls on tropospheric ozone and radiative forcing: CTM calculations for the period 19902030, Atmos. Chem. Phys., 5, 1731-1755, doi:10.5194/acp-51731-2005, 2005.

Dentener, F., Kinne, S., Bond, T., Boucher, O., Cofala, J., Generoso, S., Ginoux, P., Gong, S., Hoelzemann, J. J., Ito, A., Marelli, L., Penner, J. E., Putaud, J.-P., Textor, C., Schulz, M., van der Werf, G. R., and Wilson, J.: Emissions of primary aerosol and precursor gases in the years 2000 and 1750 prescribed data-sets for AeroCom, Atmos. Chem. Phys., 6, 4321-4344, doi:10.5194/acp6-4321-2006, 2006.

Ding, X., Zheng, M., Edgerton, E. S., Jansen, J. J., and Wang, X. M.: Contemporary or fossil origin: Split of estimated secondary organic carbon in the southeastern United States, Environ. Sci. Technol., 42(24), 9122-9128, 2008.

Dunlea, E. J., DeCarlo, P. F., Aiken, A. C., Kimmel, J. R., Peltier, R. E., Weber, R. J., Tomlinson, J., Collins, D. R., Shinozuka, Y., McNaughton, C. S., Howell, S. G., Clarke, A. D., Emmons, L. K., Apel, E. C., Pfister, G. G., van Donkelaar, A., Martin, R. V., Millet, D. B., Heald, C. L., and Jimenez, J. L.: Evolution of Asian aerosols during transpacific transport in INTEX-B, Atmos. Chem. Phys., 9, 7257-7287, doi:10.5194/acp-9-7257-2009, 2009.

Dzepina, K., Volkamer, R. M., Madronich, S., Tulet, P., Ulbrich, I. M., Zhang, Q., Cappa, C. D., Ziemann, P. J., and Jimenez, J. L.: Evaluation of recently-proposed secondary organic aerosol models for a case study in Mexico City, Atmos. Chem. Phys., 9, 5681-5709, doi:10.5194/acp-9-5681-2009, 2009.

Dzepina, K., Cappa, C. D., Volkamer, R.M., Madronich, S., DeCarlo, P. F., Zaveri, R. A., and Jimenez, J. L.: Modeling the Multiday Evolution and Aging of Secondary Organic Aerosol During MILAGRO 2006, Environ. Sci. Technol., 45, 3496-3503, doi:10.1021/es103186, 2011.

Edwards, J. M. and Slingo, A.: Studies with a flexible new radiation code: I. Choosing a configuration for a large scale model, Q. J. Roy. Meteorol. Soc., 122, 689-720, doi:10.1002/qj.49712253107, 1996.

Farina, S. C., Adams, P. J., and Pandis, S. N.: Modeling global secondary organic aerosol formation and processing with the volatility basis set: Implications for anthropogenic secondary organic aerosol, J. Geophys. Res., 115, D09202, doi:10.1029/2009JD013046, 2010.

Forster, P., Ramaswamy, V., Artaxo, P., Berntsen, T., Betts, R., Fahey, D. W., Haywood, J., Lean, J., Lowe, D. C., Myhre, G., Nganga, J., Prinn, R., Raga, G., Schulz, M., and Van Dorland, R.: Changes in Atmospheric Constituents and in Radiative Forcing, in: Climate Change 2007: The Physical Science Basis. Contribution of Working Group I to the Fourth Assessment Report of the Intergovernmental Panel on Climate Change, edited by: Solomon, S., Qin, D., Manning, M., Chen, Z., Marquis, M., Averyt, K. B., Tignor, M., and Miller, H. L., Cambridge University Press, Cambridge, United Kingdom and New York, NY, USA, 2007.

Froyd, K. D., Murphy, S. M., Murphy, D. M., de Gouw, J. A., Eddingsaas, N. C., and Wennberg, P. O.: Contribution of isoprene-derived organosulfates to free tropospheric aerosol mass, P. Natl. Acad. Sci. USA, 107(50), 21360-21365, doi:10.1073/pnas.1012561107, 2010.

George, I. J. and Abbatt, J. P. D.: Heterogeneous oxidation of atmospheric aerosol particles by gas-phase radicals, Nature Chem., 2, 713-722, doi:10.1038/nchem.806, 2010.

Goldstein, A. H. and Gallbaly, I. E.: Known and unexplored organic constituents in the Earth's Atmosphere, Environ Sci. Technol., 41(5), 1514-1521, 2007.

Hansen, D. A., Edgerton, E. S., Hartsell, B. E., Jansen, J. J., Kandasamy, N., Hidy, G. M., Blanchard, C. L.: The southeastern aerosol research and characterization study part 1: overview, Journal of Air and Waste Management Association, 53, 1460 1471, 2003.

Goldstein, A. H., Koven, C. D., Heald, C. L., and Fung, I. Y.: Biogenic carbon and anthropogenic pollutants combine to form a cooling haze over the southeastern United States, P. Natl. Acad. Sci. USA, 106(22), 8835-8840 www.pnas.org/cgi/do/10.1073/ pnas.0904128106, 2009.

Grieshop, A. P., Logue, J. M., Donahue, N. M., and Robinson, A. L.: Laboratory investigation of photochemical oxidation of organic aerosol from wood fires 1: measurement and simulation of organic aerosol evolution, Atmos. Chem. Phys., 9, 1263-1277, doi:10.5194/acp-9-1263-2009, 2009.

Guenther, A., Hewitt, C. N., Erickson, D., Fall, R., Geron, C., Graedel, T., Harley, P., Klinger, L., Lerdau, M., McKay, W. A., Pierce, T., Scholes, B., Steinbrecher, R., Tallamraju, R., Taylor, J., and Zimmerman, P.: A global model of natural volatile organic compound emissions, J. Geophys. Res., 100(D5), 88738892, 1995.

Hallquist, M., Wenger, J. C., Baltensperger, U., Rudich, Y., Simpson, D., Claeys, M., Dommen, J., Donahue, N. M., George, C., Goldstein, A. H., Hamilton, J. F., Herrmann, H., Hoffmann, T., Iinuma, Y., Jang, M., Jenkin, M. E., Jimenez, J. L., Kiendler-Scharr, A., Maenhaut, W., McFiggans, G., Mentel, Th. F., Monod, A., Prévôt, A. S. H., Seinfeld, J. H., Surratt, J. D., Szmigielski, R., and Wildt, J.: The formation, properties and impact of secondary organic aerosol: current and emerging issues, Atmos. Chem. Phys., 9, 5155-5236, doi:10.5194/acp-95155-2009, 2009.

Heald, C. L., Jacob, D. J., Park, R. J., Russell, L. M., Huebert, B. J., Seinfeld, J. H., Liao, H., and Weber, R. J.: A large organic aerosol source in the free troposphere missing from current models, Geophys. Res. Lett., 32, L18809, doi:10.1029/2005GL023831, 2005.

Heald, C. L., Jacob, D. J., Turquety, S., Hudman, R. C., Weber, R. J., Sullivan, A. P., Peltier, R. E., Atlas, E. L., de Gouw, J. A., Warneke, C., Holloway, J. S., Neuman, J. A., Flocke, F. M., and Seinfeld, J. H.: Concentrations and sources of organic carbon aerosols in the free troposphere over North America, J. Geophys. Res., 111, D23S47, doi:10.1029/2006JD007705, 2006.

Heald, C. L., Henze, D. K., Horowitz, L. W., Feddema, J., Lamarque, J.-F., Guenther, A., Hess, P. G., Vitt, F., Seinfeld, J. H., Goldstein, A. H., and Fung, I.: Predicted change in global secondary organic aerosol concentrations in response to future climate, emissions, and land use change, J. Geophys. Res., 113, D05211, doi:10.1029/2007JD009092, 2008.

Heald, C. L., Ridley, D.A., Kreidenweis, S. M., and Drury, E. E.: Satellite observations cap the atmospheric organic aerosol budget, Geophys. Res. Lett., 37, L24808, doi:10.1029/2010GL045095, 2010. 
Henze, D. K., Seinfeld, J. H., Ng, N. L., Kroll, J. H., Fu, T.-M., Jacob, D. J., and Heald, C. L.: Global modeling of secondary organic aerosol formation from aromatic hydrocarbons: highvs. low-yield pathways, Atmos. Chem. Phys., 8, 2405-2420, doi:10.5194/acp-8-2405-2008, 2008.

Hildebrandt, L., Donahue, N. M., and Pandis, S. N.: High formation of secondary organic aerosol from the photo-oxidation of toluene, Atmos. Chem. Phys., 9, 2973-2986, doi:10.5194/acp-92973-2009, 2009.

Hildemann, L. M., Klinedinst, D. B., Klouda, G. A., Currie, L. A., and Cass, G. R.: Sources of Urban Contemporary Carbon Aerosol, Environ. Sci. Technol., 28, 1565-1576, 1994.

Hodzic, A., Jimenez, J. L., Madronich, S., Aiken, A. C., Bessagnet, B., Curci, G., Fast, J., Lamarque, J.-F., Onasch, T. B., Roux, G., Schauer, J. J., Stone, E. A., and Ulbrich, I. M.: Modeling organic aerosols during MILAGRO: importance of biogenic secondary organic aerosols, Atmos. Chem. Phys., 9, 6949-6981, doi:10.5194/acp-9-6949-2009, 2009.

Hodzic, A., Jimenez, J. L., Madronich, S., Canagaratna, M. R., DeCarlo, P. F., Kleinman, L., and Fast, J.: Modeling organic aerosols in a megacity: potential contribution of semi-volatile and intermediate volatility primary organic compounds to secondary organic aerosol formation, Atmos. Chem. Phys., 10, 5491-5514, doi:10.5194/acp-10-5491-2010, 2010a.

Hodzic, A., Jimenez, J. L., Prévôt, A. S. H., Szidat, S., Fast, J. D., and Madronich, S.: Can 3-D models explain the observed fractions of fossil and non-fossil carbon in and near Mexico City?, Atmos. Chem. Phys., 10, 10997-11016, doi:10.5194/acp10-10997-2010, 2010b.

Hoyle, C. R., Boy, M., Donahue, N. M., Fry, J. L., Glasius, M., Guenther, A., Hallar, A. G., Huff Hartz, K., Petters, M. D., Petj, T., Rosenoern, T., and Sullivan, A. P.: A review of the anthropogenic influence on biogenic secondary organic aerosol, Atmos. Chem. Phys., 11, 321-343, doi:10.5194/acp-11-321-2011, 2011.

Jang, M., Czoschke, N. M., Lee, S., and Kamens, R. M.: Heterogeneous Atmospheric Aerosol Production by AcidCatalyzed Particle-Phase Reactions. Science 298, 814-817, doi:10.1126/science.1075798, 2002.

Jathar, S. H., Farina, S. C., Robinson, A. L., and Adams, P. J.: The influence of semi-volatile and reactive primary emissions on the abundance and properties of global organic aerosol, Atmos. Chem. Phys. Discuss., 11, 5493-5540, doi:10.5194/acpd11-5493-2011, 2011.

Jimenez, J. L., Canagaratna, M. R., Donahue, N. M., Prevot, A. S. H., Zhang, Q., Kroll, J. H., DeCarlo, P. F., Allan, J. D., Coe, H., Ng, N. L., Aiken, A. C., Docherty, K. S., Ulbrich, I. M., Grieshop, A. P., Robinson, A. L., Duplissy, J., Smith, J. D., Wilson, K. R., Lanz, V. A., Hueglin, C., Sun, Y. L., Tian, J., Laaksonen, A., Raatikainen, T., Rautiainen, J., Vaattovaara, P., Ehn, M., Kulmala, M., Tomlinson, J. M., Collins, D. R., Cubison, M. J., Dunlea, E. J., Huffman, J. A., Onasch, T. B., Alfarra, M. R., Williams, P. I., Bower, K., Kondo, Y., Schneider, J., Drewnick, F., Borrmann, S., Weimer, S., Demerjian, K., Salcedo, D., Cottrell, L., Griffin, R., Takami, A., Miyoshi, T., Hatakeyama, S., Shimono, A., Sun, J. Y., Zhang, Y. M., Dzepina, K., Kimmel, J. R., Sueper, D., Jayne, J. T., Herndon, S. C., Trimborn, A. M., Williams, L. R., Wood, E. C., Middlebrook, A. M., Kolb, C. E., Baltensperger, U., and Worsnop, D. R.: Evolution of organic aerosols in the atmosphere, Science, 326, 1525, doi:10.1126/science.1180353, 2009.

Kanakidou, M., Seinfeld, J. H., Pandis, S. N., Barnes, I., Dentener, F. J., Facchini, M. C., Van Dingenen, R., Ervens, B., Nenes, A., Nielsen, C. J., Swietlicki, E., Putaud, J. P., Balkanski, Y., Fuzzi, S., Horth, J., Moortgat, G. K., Winterhalter, R., Myhre, C. E. L., Tsigaridis, K., Vignati, E., Stephanou, E. G., and Wilson, J.: Organic aerosol and global climate modelling: a review, Atmos. Chem. Phys., 5, 1053-1123, doi:10.5194/acp-5-1053-2005, 2005.

Lane, T. E., Donahue, N. M., and Pandis, S. N.: Simulating secondary organic aerosol formation using volatility basis-set approach in a chemical transport model, Atmos. Environ., 42(32), 7439-7451, 2008.

Lanz, V. A., Alfarra, M. R., Baltensperger, U., Buchmann, B., Hueglin, C., and Prévôt, A. S. H.: Source apportionment of submicron organic aerosols at an urban site by factor analytical modelling of aerosol mass spectra, Atmos. Chem. Phys., 7, 1503-1522, doi:10.5194/acp-7-1503-2007, 2007.

Lapina, K., Heald, C. L., Spracklen, D. V., Arnold, S. R., Allan, J. D., Coe, H., McFiggans, G., Zorn, S. R., Drewnick, F., Bates, T. S., Hawkins, L. N., Russell, L. M., Smirnov, A., O’Dowd, C. D., and Hind, A. J.: Investigating organic aerosol loading in the remote marine environment, Atmos. Chem. Phys., 11, 88478860, doi:10.5194/acp-11-8847-2011, 2011.

Malm, W. C., Schichtel, B. A., Pitchford, M. L., Ashbaugh, L. L., and Eldred, R. A.: Spatial and monthly trends in speciated fine particle concentration in the United States, J. Geophys. Res., 109, D03306, doi:10.1029/2003JD003739, 2004.

Manktelow, P. T., Mann, G. W., Carslaw, K. S., Spracklen, D. V., and Chipperfield, M. P.: Regional and global trends in sulfate aerosol since the 1980s, Geophys. Res. Lett., 34, L14803, doi:10.1029/2006GL028668, 2007.

Mann, G. W., Carslaw, K. S., Spracklen, D. V., Ridley, D. A., Manktelow, P. T., Chipperfield, M. P., Pickering, S. J., and Johnson, C. E.: Description and evaluation of GLOMAP-mode: a modal global aerosol microphysics model for the UKCA composition-climate model, Geosci. Model Dev., 3, 519-551, doi:10.5194/gmd-3-519-2010, 2010.

Merikanto, J., Spracklen, D. V., Pringle, K. J., and Carslaw, K. S.: Effects of boundary layer particle formation on cloud droplet number and changes in cloud albedo from 1850 to 2000, Atmos. Chem. Phys., 10, 695-705, doi:10.5194/acp-10-695-2010, 2010.

Murphy, D. M., Cziczo, D. J., Froyd, K. D., Hudson, P. K., Matthew, B. M., Middlebrook, A. M., Peltier, R. E., Sullivan, A., Thomson, D. S., and Weber, R. J.: Single-particle mass spectrometry of tropospheric aerosol particles, J. Geophys. Res., 111, D23S32, doi:10.1029/2006JD007340, 2006.

Nenes, A. and Seinfeld, J. H., Parameterization of cloud droplet formation in global climate models, J. Geophys. Res., 108, 4415, doi:10.1029/2002JD002911, 2003.

Ng, N. L., Kroll, J. H., Chan, A. W. H., Chhabra, P. S., Flagan, R. C., and Seinfeld, J. H.: Secondary organic aerosol formation from m-xylene, toluene, and benzene, Atmos. Chem. Phys., 7, 3909-3922, doi:10.5194/acp-7-3909-2007, 2007a.

Ng, N. L., Chhabra, P. S., Chan, A. W. H., Surratt, J. D., Kroll, J. H., Kwan, A. J., McCabe, D. C., Wennberg, P. O., Sorooshian, A., Murphy, S. M., Dalleska, N. F., Flagan, R. C., and Seinfeld, J. H.: Effect of NOx level on secondary organic aerosol (SOA) formation from the photooxidation of terpenes, Atmos. Chem. 
Phys., 7, 5159-5174, doi:10.5194/acp-7-5159-2007, 2007b.

Ng, N. L., Kwan, A. J., Surratt, J. D., Chan, A. W. H., Chhabra, P. S., Sorooshian, A., Pye, H. O. T., Crounse, J. D., Wennberg, P. O., Flagan, R. C., and Seinfeld, J. H.: Secondary organic aerosol (SOA) formation from reaction of isoprene with nitrate radicals $\left(\mathrm{NO}_{3}\right)$, Atmos. Chem. Phys., 8, 4117-4140, doi:10.5194/acp-84117-2008, 2008.

Odum, J. R., Hoffmann, T., Bowman, F., Collins, D., Flagan, R. C., and Seinfeld, J. H.: Gas/particle partitioning and secondary organic aerosol yields, Environ. Sci. Technol., 30, 2580-2585, 1996.

Pöschl, U., Martin, S. T., Sinha, B., Chen, Q., Gunthe, S. S., Huffman, J. A., Borrmann, S., Farmer, D. K., Garland, R. M., Helas, G., Jimenez, J. L., King, S. M., Manzi, A., Mikhailov, E., Pauliquevis, T., Petters, M. D., Prenni, A. J., Roldin, P., Rose, D., Schneider, J., Su, H., Zorn, S. R., Artaxo, P., and Andreae, M. O.: Rainforest aerosols as biogenic nuclei of clouds and precipitation in the Amazon, Science, 329, 1513-1516, doi:10.1126/science.1191056, 2010.

Putaud, J.-P., Raes, F., Van Dingenen, R., Brüggemann, E., Facchini, M. C., Decesari, S., Fuzzi, S., Gehrig, R., Hüglin, C., Laj, P., Lorbeer, G., Maenhaut, W., Mihalopoulos, N., Mlller, K., Querol, X., Rodriguez, S., Schneider, J., Spindler, G., ten Brink, H., Trseth, K., and Wiedensohler, A.: European aerosol phenomenology: 2. Chemical characteristics of particulate matter at kerbside, urban, rural and background sites in Europe, Atmos. Environ., 38(16), 2579-2595, doi:10.1016/j.atmosenv.2004.01.041, 2004.

Pye, H. O. T. and Seinfeld, J. H.: A global perspective on aerosol from low-volatility organic compounds, Atmos. Chem. Phys., 10, 4377-4401, doi:10.5194/acp-10-4377-2010, 2010.

Rap, A., Forster, P. M., Jones, A., Boucher, O., Haywood, J. M., Bellouin, N., and De Leon, R. R.: Parameterisation of contrails in the UK Met Office Climate Model, J. Geophys. Res., 115, D10205, doi:10.1029/2009JD012443, 2010.

Riipinen, I., Pierce, J. R., Yli-Juuti, T., Nieminen, T., Hkkinen, S., Ehn, M., Junninen, H., Lehtipalo, K., Petäjä, T., Slowik, J., Chang, R., Shantz, N. C., Abbatt, J., Leaitch, W. R., Kerminen, V.-M., Worsnop, D. R., Pandis, S. N., Donahue, N. M., and Kulmala, M.: Organic condensation: a vital link connecting aerosol formation to cloud condensation nuclei $(\mathrm{CCN})$ concentrations, Atmos. Chem. Phys., 11, 3865-3878, doi:10.5194/acp-11-38652011, 2011.

Robinson, A. L., Donahue, N. M., Shrivastava, M. K., Weitkamp, E. A., Sage, A. M., Grieshop, A. P., Lane, T. E., Pierce, J. R., and Pandis, S. N.: Rethinking organic aerosols: Semivolatile emissions and photochemical ageing, Science, 315(5816), 12591262, 2007.

Robinson, N. H., Hamilton, J. F., Allan, J. D., Langford, B., Oram, D. E., Chen, Q., Docherty, K., Farmer, D. K., Jimenez, J. L., Ward, M. W., Hewitt, C. N., Barley, M. H., Jenkin, M. E., Rickard, A. R., Martin, S. T., McFiggans, G., and Coe, H.: Evidence for a significant proportion of Secondary Organic Aerosol from isoprene above a maritime tropical forest, Atmos. Chem. Phys., 11, 1039-1050, doi:10.5194/acp-11-1039-2011, 2011.

Rossow, W. B. and Schiffer, R. A.: Advances in understanding clouds from ISCCP, B. Am. Meteorol. Soc., 80, 2261-2288, 1999.

Schichtel, B. A.: Fossil and contemporary fine particulate carbon fractions at 12 rural and urban sites in the United States, J. Geophys. Res.-Atmos., 113, D02311, doi:10.1029/2007JD008605, 2008.

Slowik, J. G., Stroud, C., Bottenheim, J. W., Brickell, P. C., Chang, R. Y.-W., Liggio, J., Makar, P. A., Martin, R. V., Moran, M. D., Shantz, N. C., Sjostedt, S. J., van Donkelaar, A., Vlasenko, A., Wiebe, H. A., Xia, A. G., Zhang, J., Leaitch, W. R., and Abbatt, J. P. D.: Characterization of a large biogenic secondary organic aerosol event from eastern Canadian forests, Atmos. Chem. Phys., 10, 2825-2845, doi:10.5194/acp-10-2825-2010, 2010.

Spracklen, D. V., Pringle, K. J., Carslaw, K. S., Chipperfield, M. P., and Mann, G. W.: A global off-line model of sizeresolved aerosol microphysics: I. Model development and prediction of aerosol properties, Atmos. Chem. Phys., 5, 2227 2252, doi:10.5194/acp-5-2227-2005, 2005a.

Spracklen, D. V., Pringle, K. J., Carslaw, K. S., Chipperfield, M. P., and Mann, G. W.: A global off-line model of size-resolved aerosol microphysics: II. Identification of key uncertainties, Atmos. Chem. Phys., 5, 3233-3250, doi:10.5194/acp-5-3233-2005, 2005b.

Spracklen, D. V., Carslaw, K. S., Kulmala, M., Kerminen, V.-M., Mann, G. W., and Sihto, S.-L.: The contribution of boundary layer nucleation events to total particle concentrations on regional and global scales, Atmos. Chem. Phys., 6, 5631-5648, doi:10.5194/acp-6-5631-2006, 2006.

Spracklen, D. V., Logan, J. A., Mickley, L. J., Park, R. J., Yevich, R., Westerling, A. L., and Jaffe, D. A.: Wildfires drive interannual variability of organic carbon aerosol in the western U.S. in summer, Geophys. Res. Lett., 34, L16816, doi:10.1029/2007GL030037, 2007.

Spracklen, D. V., Carslaw, K. S., Kulmala, M., Kerminen, V.-M., Sihto, S.-L., Riipinen, I., Merikanto, J., Mann, G. W., Chipperfield, M. P., Wiedensohler, A., Birmili, W., and Lihavainen, H.: Contribution of particle formation to global cloud condensation nuclei concentrations, Geophys. Res. Lett., 35, L06808, doi:10.1029/2007GL033038, 2008a.

Spracklen, D. V., Arnold, S. R., Sciare, J., Carslaw, K. S., and Pio, C.: Globally significant oceanic source of organic carbon aerosol, Geophys. Res. Lett., 35, L12811, doi:10.1029/2008GL033359, 2008b.

Sun, Y., Zhang, Q., Macdonald, A. M., Hayden, K., Li, S. M., Liggio, J., Liu, P. S. K., Anlauf, K. G., Leaitch, W. R., Steffen, A., Cubison, M., Worsnop, D. R., van Donkelaar, A., and Martin, R. V.: Size-resolved aerosol chemistry on Whistler Mountain, Canada with a high-resolution aerosol mass spectrometer during INTEX-B, Atmos. Chem. Phys., 9, 3095-3111, doi:10.5194/acp9-3095-2009, 2009.

Surratt, J. D., Chan, A. W. H., Eddingsaas, N. C., Chan, M. N., Loza, C. L., Kwan, A. J., Hersey, S. P., Flagan, R. C., Wennberg, P. O., and Seinfeld, J. H.: Reactive intermediates revealed in secondary organic aerosol formation from isoprene, P. Natl. Acad. Sci. USA, 107, 6640-6645, 2010.

Szidat, S., Ruff, M., Perron, N., Wacker, L., Synal, H.-A., Hallquist, M., Shannigrahi, A. S., Yttri, K. E., Dye, C., and Simpson, D. Fossil and non-fossil sources of organic carbon (OC) and elemental carbon (EC) in Göteborg, Sweden, Atmos. Chem. Phys., 9, 1521-1535, doi:10.5194/acp-9-1521-2009, 2009.

an, Y., Carlton, A. G., Seitzinger, S.P., Turpin, B. J., SOA from methlyglyoxal in clouds and wet aerosols: Measurement and pre- 
diction of key products, Atmos. Env., 44 (39), 5128-5226, 2010.

Textor, C., Schulz, M., Guibert, S., Kinne, S., Balkanski, Y., Bauer, S., Berntsen, T., Berglen, T., Boucher, O., Chin, M., Dentener, F., Diehl, T., Easter, R., Feichter, H., Fillmore, D., Ghan, S., Ginoux, P., Gong, S., Grini, A., Hendricks, J., Horowitz, L., Huang, P., Isaksen, I., Iversen, I., Kloster, S., Koch, D., Kirkevåg, A., Kristjansson, J. E., Krol, M., Lauer, A., Lamarque, J. F., Liu, X., Montanaro, V., Myhre, G., Penner, J., Pitari, G., Reddy, S., Seland, Ø., Stier, P., Takemura, T., and Tie, X.: Analysis and quantification of the diversities of aerosol life cycles within AeroCom, Atmos. Chem. Phys., 6, 1777-1813, doi:10.5194/acp-61777-2006, 2006.

Tsigaridis, K., Krol, M., Dentener, F. J., Balkanski, Y., Lathière, J., Metzger, S., Hauglustaine, D. A., and Kanakidou, M.: Change in global aerosol composition since preindustrial times, Atmos. Chem. Phys., 6, 5143-5162, doi:10.5194/acp-6-5143-2006, 2006.

Tsigaridis, K. and Kanakidou, M.: Secondary organic aerosol importance in the future atmosphere, Atmos. Environ., 41, 46824692, 2007.

Tsimpidi, A. P., Karydis, V. A., Zavala, M., Lei, W., Molina, L., Ulbrich, I. M., Jimenez, J. L., and Pandis, S. N.: Evaluation of the volatility basis-set approach for the simulation of organic aerosol formation in the Mexico City metropolitan area, Atmos. Chem. Phys., 10, 525-546, doi:10.5194/acp-10-525-2010, 2010.

Tunved, P., Hansson, H.-C., Kerminen, V.-M., Ström, J., Dal Maso, M., Lihavainen, H., Viisanen, Y., Aalto, P. P., Komppula, M., and Kulmala, M.: High natural aerosol loading over boreal forests, Science, 312, 261-263, doi:10.1126/science.1123052, 2006.

Turpin, B. J. and Lim, H. J.: Species contributions to PM2.5 mass concentrations: Revisiting common assumptions for estimating organic mass, Aerosol Sci. Technol., 35(1), 602-610, 2001.

Ulbrich, I. M., Canagaratna, M. R., Zhang, Q., Worsnop, D. R., and Jimenez, J. L.: Interpretation of organic components from Positive Matrix Factorization of aerosol mass spectrometric data, Atmos. Chem. Phys., 9, 2891-2918, doi:10.5194/acp-9-2891-2009, 2009.

Vaden, T. D., Imre, D., Beranek, J., Shrivastava, M., Zelenyuk, A.: Evaporation kinetics and phase of laboratory and ambient secondary organic aerosol, P. Natl. Acad. Sci. USA, 108(6), 21902195, 2011.

van der Werf, G. R., Randerson, J. T., Collatz, G. J., Giglio, L., Kasibhatla, P. S., Arellano, A. F., Olsen, S. C., and Kasischke, E. S.: Continental-scale partitioning of fire emissions during the 1997 to $2001 \mathrm{El}$ Nino/La Nina period, Science, 303(5654), 7376, 2004.

Virtanen, A., Joutsensaari, J., Koop, T., Kannosto, J., Yli-Pirilä, P., Leskinen, J., Mäkelä, J. M., Holopainen, J. K., Pöschl, U., Kulmala, M., Worsnop, D. R., and Laaksonen, A.: An amorphous solid state of biogenic secondary organic aerosol particles, Nature, 467, 824-827, doi:10.1038/nature09455, 2010.
Volkamer, R., Jimenez, J. L., San Martini, F., Dzepina, K., Zhang, Q., Salcedo, D., Molina, L. T., Worsnop, D. R., and Molina, M. J.: Secondary organic aerosol formation from anthropogenic air pollution: Rapid and higher than expected, Geophys. Res. Lett., 33, L17811, doi:10.1029/2006GL026899, 2006.

Weber, R. J., Sullivan, A. P., Peltier, R. E., Russell, A., Yan, B., Zheng, M., de Gouw, J., Warneke, C., Brock, C., Holloway, J. S., Atlas, E. L., and Edgerton, E.: A study of secondary organic aerosol formation in the anthropogenicinfluenced southeastern United States, J. Geophys. Res., 112, D13302, doi:10.1029/2007JD008408, 2007.

Worton, D. R., Goldstein, A. H., Farmer, D. K., Docherty, K. S., Jimenez, J. L., Gilman, J. B., Kuster, W. C., de Gouw, J., Williams, B. J., Kreisberg, N. M., Hering, S. V., Bench, G., McKay, M., Kristensen, K., Glasius, M., Surratt, J. D., and Seinfeld, J. H.: Origins and composition of fine atmospheric carbonaceous aerosol in the Sierra Nevada Mountains, California, Atmos. Chem. Phys., 11, 10219-10241, doi:10.5194/acp11-10219-2011, 2011.

Yassaa, N., Peeken, I., Zollner, E., Bluhm, K., Arnold, S., Spracklen, D., and Williams, J.: Evidence for marine production of monoterpenes, Environ. Chem., 5(6), 391-401, 2008.

Yokelson, R. J., Crounse, J. D., DeCarlo, P. F., Karl, T., Urbanski, S., Atlas, E., Campos, T., Shinozuka, Y., Kapustin, V., Clarke, A. D., Weinheimer, A., Knapp, D. J., Montzka, D. D., Holloway, J., Weibring, P., Flocke, F., Zheng, W., Toohey, D., Wennberg, P. O., Wiedinmyer, C., Mauldin, L., Fried, A., Richter, D., Walega, J., Jimenez, J. L., Adachi, K., Buseck, P. R., Hall, S. R., and Shetter, R.: Emissions from biomass burning in the Yucatan, Atmos. Chem. Phys., 9, 5785-5812, doi:10.5194/acp-9-5785-2009, 2009

Zhang, Q., Worsnop, D. R., Canagaratna, M. R., and Jimenez, J. L.: Hydrocarbon-like and oxygenated organic aerosols in Pittsburgh: insights into sources and processes of organic aerosols, Atmos. Chem. Phys., 5, 3289-3311, doi:10.5194/acp-5-32892005, 2005.

Zhang, Q., Jimenez, J. L., Canagaratna, M. R., Allan, J. D., Coe, H., Ulbrich, I., Alfarra, M. R., Takami, A., Middlebrook, A. M., Sun, Y. L., Dzepina, K., Dunlea, E., Docherty, K., DeCarlo, P. F., Salcedo, D., Onasch, T., Jayne, J. T., Miyoshi, T., Shimono, A., Hatakeyama, S., Takegawa, N., Kondo, Y., Schneider, J., Drewnick, F., Borrmann, S., Weimer, S., Demerjian, K., Williams, P., Bower, K., Bahreini, R., Cottrell, L., Griffin, R. J., Rautiainen, J., Sun, J. Y., Zhang, Y. M., and Worsnop, D. R.: Ubiquity and dominance of oxygenated species in organic aerosols in anthropogenically-influenced Northern Hemisphere midlatitudes, Geophys. Res. Lett., 34, L13801, doi:10.1029/2007GL029979, 2007. 